\title{
AVALIAÇÃO IN VITRO DA MICROINFILTRAÇÃO MARGINAL DE RESTAURAÇÕES DE AMÁLGAMA EM CAVIDADES CLASSE II ASSOCIADAS A ADESIVO DENTINÁRIO, CIMENTO DE IONÔMERO DE VIDRO E VERNIZ CAVITÁRIO
}

\section{Adriano Tomio Hoshi}

Dissertação apresentada à Faculdade de Odontologia de Bauru, da Universidade de São Paulo, como parte dos requisitos para obtenção do título de Mestre em Odontologia - área de Odontopediatria.

(Edição Revisada) 


\section{AVALIAÇÃO IN VITRO DA MICROINFILTRAÇÃO MARGINAL DE RESTAURAÇÕES DE AMÁLGAMA EM CAVIDADES CLASSE II ASSOCIADAS A ADESIVO DENTINÁRIO, CIMENTO DE IONÔMERO DE VIDRO E VERNIZ CAVITÁRIO}

\section{Adriano Tomio Hoshi}

Dissertação apresentada à Faculdade de Odontologia de Bauru, da Universidade de São Paulo, como parte dos requisitos para obtenção do título de Mestre em Odontologia - área de Odontopediatria.

(Edição Revisada)

Orientadora:

Prof $^{\underline{a}}$ Dr $^{\mathrm{a}}$ Salete Moura Bonifácio da Silva

BAURU

2000 


\section{Hoshi, Adriano Tomio}

H792a Avaliação in vitro da microinfiltração marginal de restaurações de amálgama em cavidades classe II associadas a adesivo dentinário, cimento de ionômero de vidro e verniz cavitário / Adriano Tomio Hoshi - Bauru, 2000. 138p.: il.; $30 \mathrm{~cm}$.

Dissertação (Mestrado) - Faculdade de Odontologia de Bauru, USP.

Orientadora: $\operatorname{Prof}^{\mathrm{a}}{ }^{\mathrm{Dr}}{ }^{\mathrm{a}}$ Salete Moura Bonifácio da Silva

Autorizo, exclusivamente para fins acadêmicos e científicos, a reprodução total ou parcial desta dissertação por processos fotocopiadores e/ou meios eletrônicos.

Assinatura do autor:

Data: 


\section{ADRIANO TOMIO HOSHI}

08 de setembro de 1976

Uraí - PR

Filiação

$1994-1997$

$1995-1997$

$1998-2000$

2000

Associações
Nascimento

Jorge Toshimitsu Hoshi

Adelina Midori Hoshi

Curso de Graduação em Odontologia Faculdade de Odontologia de Bauru Universidade de São Paulo

Bolsista PET - CAPES

Curso de Pós - Graduação em Odontologia em nível de Mestrado, Área de Odontopediatria Faculdade de Odontologia de Bauru Universidade de São Paulo

Professor Auxiliar da Disciplina de Odontopediatria da Faculdade de Odontologia da Universidade Estadual do Oeste do Paraná, Cascavel - PR

APCD - Associação Paulista de Cirurgiões Dentistas

SBPqO - Sociedade Brasileira de Pesquisa Odontológica 
"Toda a nossa ciência, comparada com a realidade, é primitiva e infantil - e, no entanto, é a coisa mais preciosa que temos."

\section{Albert Einstein}

"Temos a tentação poderosa de procurar as evidências $e$ aparências que estão a favor de nossos desejos, $e$ desconsiderar as que fazem oposição. Acolhemos com boa vontade o que concorda com nossas idéias, assim como resistimos com desgosto ao que se opõe a nós, enquanto todo o preceito de bom senso exige exatamente o contrário."

Michael Faraday - físico britânico 


\title{
DEDICATÓRIA
}

\author{
Aos meus pais
}

Jorge Toshimitsu Hoshi

Adelina Midori Hoshi

A vocês, exemplos de dedicação, trabalho e amor pela família, que sempre estiveram me ensinando a trilhar os árduos caminhos da vida e nunca mediram esforços para garantir meus estudos, sonhos e ideais.

Hoje colho os frutos das sementes que juntos plantamos...

É difícil transformar em palavras sentimentos tão intensos de amor e gratidão...

\section{Aos meus irmãos \\ Frank Toshio Hoshi, Edgard Hideaki Hoshi e Vander Koji Hoshi}

No passado, brincamos e crescemos juntos...

Infelizmente, em busca de minha melhor formação, não pude estar sempre ao lado de vocês.

O presente mostra-me o quanto vocês amadureceram. Hoje são homens dedicados, inteligentes e responsáveis, dos quais me orgulho muito!

Obrigado pelo incentivo, companheirismo e pelos bons momentos vividos. 


\title{
Aos meus avós
}

\section{Seiji Hoshi \\ Tamae Hoshi (in memorian)}

\section{Jiichi Ito (in memorian) \\ Hatsue Ito}

Vocês, que desbravaram um pais totalmente desconhecido em busca de seus ideais, são verdadeiros exemplos de luta e perseverança.

Nos momentos de dificuldade, penso no quanto vocês trabalharam e se esforçaram, sempre com dignidade e humildade.

Agradeço pelo amor, pelo incentivo e pela atenção.

\section{À minha namorada}

\begin{abstract}
Susana
"Um bem querer é alguém que a gente ama de verdade, alguém que partilha nossos planos e esperanças e ajuda a transformar nossos sonhos em realidade. Alguém cujo rosto a gente anseia por ver, alguém que a gente quer ouvir, alguém que faz soar uma canção de amor no coração da gente, apenas estando presente.

Alguém que conhece as nossas falhas e nos ama de todo o modo, que sempre sente as coisas que as palavras não podem expressar. Alguém por quem vale a pena esperar - a razão da gente ser feliz... ...sentir que ama alguém."

Obrigado por compreender minhas ausências, pelo companheirismo, pela amizade que supera qualquer distância e por todas as atitudes que fazem de você o meu amor.
\end{abstract}

A vocês, dedico este trabalho!!! 


\section{AGRADECIMENTOS ESPECIAIS}

\section{A DEUS,}

Agradeço por ter me concedido a vida, por iluminar meus caminhos e por me dar forças para continuar esta jornada.

\section{À Profa Dra Salete Moura Bonifácio da Silva,}

Uma pessoa de capacidade incomum, que alia talento profissional, humildade e sensatez, desprendida de vaidades e arrogâncias.

Suas atitudes refletem claramente a pessoa que você é.

"Não basta ensinar ao homem uma especialidade, porque se tornará assim uma máquina utilizável e não uma personalidade. É necessário que adquira um sentimento, um senso prático daquilo que vale a pena ser empreendido, daquilo que é belo, do que é moralmente correto."

Albert Einstein

Agradeço profundamente pela orientação precisa, atenciosa e amiga que recebo há tempos, além do incentivo e confiança em mim depositados.

Obrigado por me direcionar aos caminhos do ensino e pesquisa. Sou grato por você ter aberto as portas desta especialidade gratificante e humana que é a Odontopediatria. 
A todos os meus familiares,

Pelo apoio constante, pela amizade e por participarem da minha vida.

Ao S. Augusto e D. Sandra,

Por todo o carinho e atenção dispensados ao longo desses anos.

Ao grande amigo Vagner Leme Ortega,

Aprendi a admirá-lo durante estes anos, por sua amizade sincera, dedicação, apoio e pelo convivio amistoso e fraterno. Jamais esquecerei os bons momentos de risos e de estudos, que se misturavam facilmente nas longas noites em que buscávamos conhecer um pouco mais de Odontologia.

Meus sinceros agradecimentos por tudo... 


\section{AGRADECIMENTOS}

\section{À Faculdade de Odontologia de Bauru,}

Na pessoa do Prof. Dr. Aymar Pavarini, diretor desta faculdade.

Aos mestres, por minha formação e por partilharem seus conhecimentos e vivências.

À Comissão de Pós-graduação,

Na pessoa do presidente Prof. Dr. Luís Fernando Pegoraro.

À Fundação de Amparo à Pesquisa do Estado de São Paulo,

Por possibilitar a realização deste trabalho.

Aos Prof.s Dr.s da Disciplina de Odontopediatria,

Aymar Pavarini, Bernardo Gonzáles Vono, José Eduardo de Oliveira Lima, Maria Aparecida de Andrade Moreira Machado, Maria Francisca Thereza Borro Bijella, Ruy César Camargo Abdo e Salete Moura Bonifácio da Silva, por minha formação nesta especialidade.

Ao Prof. Dr. Eduardo Batista Franco,

Jamais esquecerei quem primeiro me despertou para a vida acadêmica, incentivando-me a trilhar os caminhos da pós-graduação, sempre com muita seriedade, ponderação e sabedoria.

Obrigado pela confiança, apoio e amizade.

Ao Prof $\underline{a}$ Dra Denise Tostes Oliveira,

Pela amizade, incentivo constante e pelas orientações precisas e tranqüilizadoras.

Ao Prof. Dr. José Roberto Pereira Lauris,

Pela atenção e colaboração na análise estatística. 
Aos funcionários da Disciplina de Odontopediatria,

D. Wilma, D. Lia, Fátima, Lilian, Estela, Kelly, Paulo e Lidiane, pela amizade e por toda a atenção e presteza com que me recebiam.

Aos funcionários da Pós-graduação,

Giane, Aurélio, Sônia, Neide e Ana, pela atenção.

Aos Departamentos de Dentistica e Bioquimica,

Por cederem seus equipamentos e dependências para a realização deste trabalho, especialmente aos funcionários Nelson, Ovídio e Telma.

Aos funcionários da Biblioteca,

Ademir, César, Cybelle, Valéria e Vera, pela colaboração e orientação para realizar este trabalho.

Aos amigos do curso de Mestrado,

Ana Carla, Ana Luiza, Cleide, Daniela, Fernanda, Livia, Marina, Paloma e Patrícia, pelo companheirismo, pela amizade e por compartilharem todos os bons e os dificeis momentos do curso. Valeu a pena!!!

Especialmente à Cleide, uma pessoa extremamente competente, talentosa e objetiva, que dividiu comigo sua grande experiência durante as clínicas. Você foi, para mim, uma verdadeira orientadora!!!

Aos amigos do curso de Doutorado,

Edmêr, Fabiana, Maria Ligia, Sara e Cadu, pelos conselhos preciosos e pela amizade.

Aos amigos da Pós-graduação,

Em especial, ao Anuar, Carlinhos, Christian, Luciana Reis, Linda e Roberto Bombonatti, pela amizade constante e confortante, pela atenção e por todos os bons momentos. 
Aos amigos da XXXIII Turma da Faculdade de Odontologia de Bauru,

Pela amizade, por todos os momentos vividos e por compartilharem muitos sonhos e expectativas.

Aos amigos do alojamento,

Nilson, Ovo, Djalma, Celso, Márcio, Willian, Érik, Adriano, Edson, Vô, Ken, Zanda, Ronieder, Rodolfo, Moicano, Jabá e Féster, pela companhia, pela amizade e pelas alegrias.

Aos amigos do grupo PET - FOB,

Daniela, Juliano, Silvia, Vanessa, Caio, Linda, Madeira, Marcela, Andréia, Heloíza, Luciana, Andréia, Célia, Fernanda, Lúcia, Vítor, Carla, Milena, Nicole e Paulo. Aprendi muito com vocês!!!

Aos alunos da graduação da FOB, Pela atenção, amizade e apoio. 


\section{À Universidade Estadual do Oeste do Paraná,}

Por possibilitar meu ingresso na carreira docente.

Aos professores do Curso de Odontologia da Universidade Estadual do Oeste do Paraná,

Representados pelo Prof. Rolando Plümer Pezzini. Em especial, aos Profs. Edo Hirata, Denise César de Oliveira Davidoff e Maria de Fátima Monteiro Thomazinho, pela amizade, pela compreensão e pelo convivio na disciplina de Odontopediatria.

Aos alunos da I Turma do Curso de Odontologia da Universidade Estadual do Oeste do Paraná,

Ingressei nesta faculdade com 0 intuito de ensinar, mas, na realidade, fui eu a pessoa que mais aprendeu.

Obrigado por tudo, principalmente por mostrarem que a vida de professor realmente vale a pena.

Aos pacientes,

Através de vocês, pude aprender e ensinar. 


\section{SUMÁRIO}

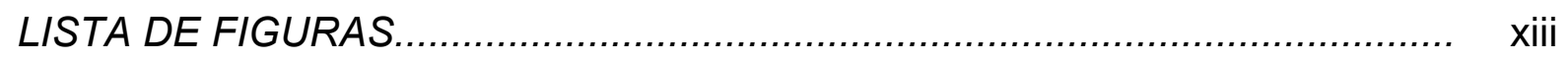

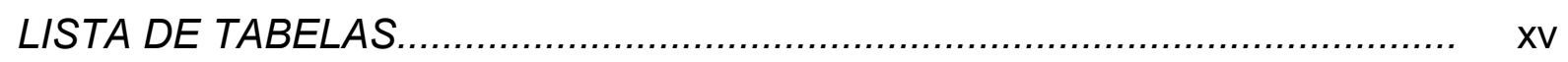

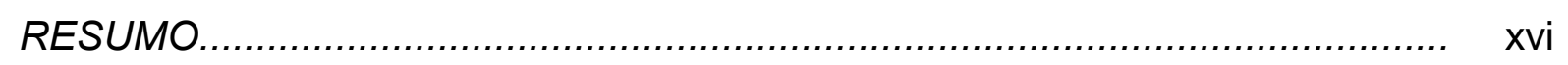

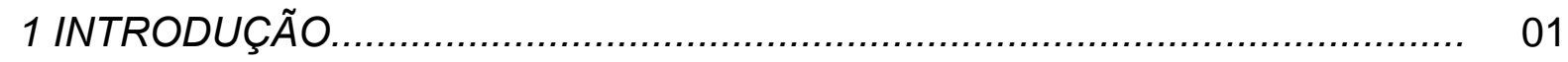

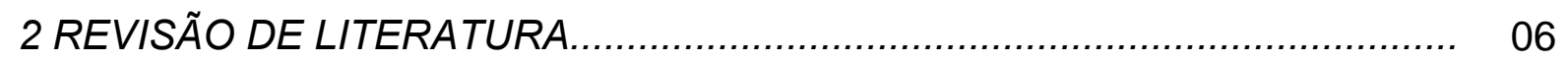

2.1 Microinfiltração marginal com verniz cavitário................................ 07

2.2 Microinfiltração marginal com materiais adesivos............................ 18

2.3 Variáveis que podem influenciar nos testes de microinfiltração

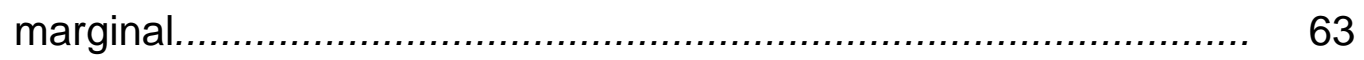

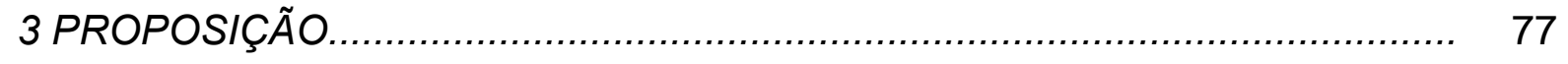

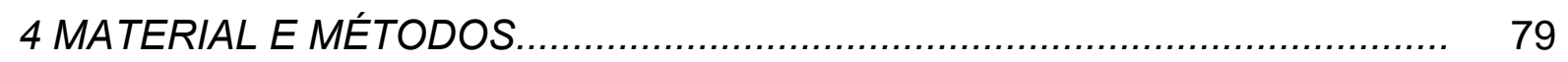

4.1 Seleção dos dentes................................................................ 80

4.2 Realização dos preparos cavitários............................................. 80

4.3 Material usado e grupos de estudo............................................. 83

4.4 Realização das restaurações.................................................... 88

4.5 Termociclagem e penetração do corante...................................... 89

4.6 Realização dos seccionamentos.............................................. $\quad 90$

4.7 Avaliação da microinfiltração marginal............................................ 91

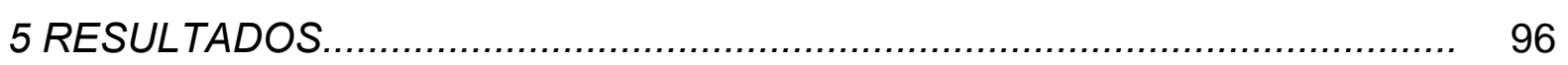

6 DISCUSSÃO

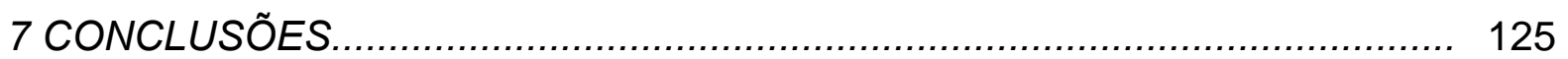

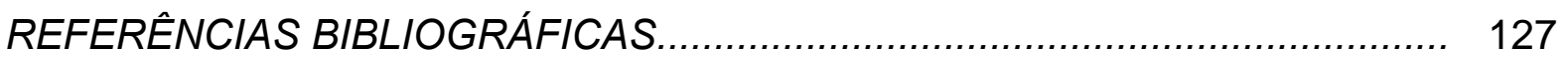

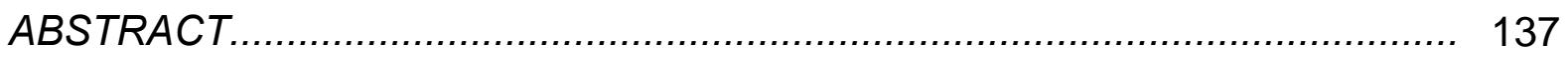




\section{LISTA DE FIGURAS}

Figura 1- Extensão vestíbulo-lingual do preparo cavitário.

Figura 2- Profundidade do preparo cavitário

Figura 3- Limites do preparo cavitário

Figura 4- Material utilizado e seus respectivos dados de fabricação

Figura 5- Dente a ser restaurado montado no bloco de gesso.

Figura 6- Liga de amálgama e mercúrio

Figura 7- Verniz cavitário COPALITE

Figura 8- Sistema adesivo OPTIBOND SOLO.

Figura 9- CIV modificado por resina VITREMER

Figura 10- Restauração finalizada

Figura 11- Espécime após a aplicação de esmalte de unhas.

Figura 12- Espécime montado para a realização dos seccionamentos.

Figura 13- Conjunto de fatias obtidas através do seccionamento de um dente

Figura 14- Medida da microinfiltração marginal pelo microscópio.

Figura 15- Medida da microinfiltração marginal pelo método Sigma única. 
Figura 16- Medida da microinfiltração marginal pelo método Sigma segm

Figura 17- Valores médios da microinfiltração marginal $(\mathrm{mm})$ observada nos grupos de estudo, obtidos através dos três métodos de avaliação.

Figura 18- Valores médios da microinfiltração marginal $(\mathrm{mm})$ observada nos grupos de estudo, obtidos através dos três métodos de avaliação.

Figura 19- Aspecto característico da microinfiltração marginal no GI - CP......... 104

Figura 20- Aspecto característico da microinfiltração marginal no Gll - OS 104

Figura 21- Aspecto característico da microinfiltração marginal no GIII - VT...... 104 


\section{LISTA DE TABELAS}

Tabela 1- Valores da microinfiltração marginal $(\mathrm{mm})$ observada nos grupos de estudo, obtidos através dos três métodos de avaliação

Tabela 2- Parâmetros da ANOVA para os grupos de estudo nos três métodos de avaliação empregados.

Tabela 3- Teste de TUKEY para comparações entre os grupos de estudo para cada método de avaliação empregado

Tabela 4- Parâmetros da ANOVA para os métodos de avaliação empregados considerando os três grupos de estudo.

Tabela 5- Teste de TUKEY para comparações entres métodos de avaliação para cada grupo estudado.

Tabela 6- Parâmetros da Correlação de Pearson entre os métodos de avaliação empregados. 


\section{RESUMO}

Em Odontopediatria, o amálgama dentário ainda é muito utilizado, uma vez que é altamente resistente, insolúvel aos fluídos bucais, de baixo custo e de fácil manipulação, não sendo um material de alta sensibilidade técnica. A sua grande desvantagem é a falta de adesão à estrutura dentária, associada à microinfiltração marginal. Entretanto, estes problemas tendem a ser reduzidos através de sua associação aos adesivos dentinários ou aos cimentos de ionômero de vidro (CIV), quando comparados ao verniz cavitário. Este trabalho avaliou, in vitro, a microinfiltração marginal de restaurações de amálgama associadas ao verniz cavitário Copalite - Cooley \& Cooley (GI - CP), ao adesivo dentinário OptiBond Solo - Kerr (GII - OS) e ao CIV Vitremer - 3M Dental Products (GIII - VT). Foram utilizados 45 pré-molares hígidos e extraídos, que receberam cavidades independentes classe II nas faces mesial e distal, envolvendo as cristas marginais. Todas as cavidades foram restauradas com a liga Dispersalloy - Dentsply, sendo que, posteriormente, os dentes sofreram termociclagem nas temperaturas de $5^{\circ} \mathrm{C}$ e $55^{\circ} \mathrm{C}$ por 500 ciclos, com banhos de 15 segundos em água deionizada. Os dentes foram então armazenados em solução de fucsina básica a 0,5\% por 24 horas, a $37^{\circ} \mathrm{C}$. Após este período, foram lavados em água corrente por 24 horas e seccionados no sentido mésio-distal. As fatias obtidas foram avaliadas em um microscópio óptico com aumento de 150 vezes (Mitutoyo TM-505) e no software Sigma Scan, utilizando linha única e linhas segmentadas. A análise dos dados obtidos permitiu constatar que nenhum dos materiais foi capaz de eliminar a microinfiltração marginal, sendo que o Gl - CP apresentou valores maiores e estatisticamente significantes em relação aos demais grupos em todos os métodos de avaliação. Os menores valores foram obtidos pelo GIII - VT, porém sem diferença estatisticamente significante quando comparado ao GII - OS, exceto pela avaliação no Sigma Scan em linha única, para um valor de $p<0,05$. Os três métodos de avaliação de medidas lineares empregados mostraram ter uma forte correlação positiva, apesar de apresentarem resultados estatisticamente diferentes entre si em pelo menos um dos grupos de estudo. 


\section{INTRODUÇÃO}

A Odontologia atual está voltada com ênfase à prevenção das doenças bucais, principalmente a cárie dentária. Além dos métodos preventivos, muito tem sido pesquisado quanto aos materiais restauradores e suas técnicas de aplicação, aumentando, em muito, as opções de tratamento existentes no mercado.

Apesar do advento de materiais restauradores estéticos indicados para restauração de dentes posteriores, o amálgama dentário, utilizado desde 1826 na Dentística Restauradora ${ }^{80}$, ainda continua sendo a opção de tratamento mais viável nestes $\operatorname{casos}^{89}$. Esse material possui excelentes propriedades físicas e mecânicas, sendo altamente resistente ao desgaste e aos esforços mastigatórios, insolúvel aos fluidos bucais, de fácil manipulação e inserção, de baixo custo, além de ter uma baixa sensibilidade técnica ${ }^{30,45,58,60,80}$, o que se constitui numa vantagem para o tratamento de pacientes jovens ${ }^{52}$.

Porém, como todos os materiais restauradores, o amálgama também possui falhas e limitações, tais como a cor e a falta de adesão à estrutura dentária, além de receber críticas devido aos efeitos tóxicos do mercúrio ${ }^{53,57,89,100}$.

Sua falta de adesão aos tecidos dentários é uma grande desvantagem, já que torna necessária a realização de retenções adicionais em muitos casos, através de um desgaste de estrutura sadia para a formação de sulcos ou canaletas ${ }^{3,30,60}$. Um outro problema associado a esse tipo de restauração é a formação de uma fenda na interface dente/restauração que varia de 10 a 15 micrometros $^{14}$, a qual permite a microinfiltração marginal. Este fenômeno é definido como a penetração de fluidos bucais, bactérias, moléculas e íons entre a parede cavitária e o material restaurador $^{51}$, possibilitando a ocorrência de cárie secundária e irritação pulpar, além de comprometer a longevidade da restauração ${ }^{18,14,22,53,109}$. Outros fatores que podem contribuir para a ocorrência de microinfiltração marginal em restaurações de amálgama são inerentes ao próprio material, como as alterações dimensionais na presa e o coeficiente de expansão térmica linear diferente daquele do dente, além do operador, devido à trituração inadequada ou à adaptação deficiente às paredes cavitárias $^{13,53}$. 
Deve-se salientar, no entanto, que o amálgama é o único material restaurador conhecido capaz de aumentar o vedamento marginal com o decorrer do tempo. Isso ocorre através do depósito de produtos oriundos de sua corrosão na interface dente/restauração ${ }^{14,19,66,80}$.

O amálgama convencional, composto por ligas com baixo conteúdo de cobre (2 a 4\%), apresenta uma quantidade considerável de fase gama $2\left(\mathrm{Sn}_{8} \mathrm{Hg}\right)$, a qual é mais propensa à corrosão, prejudicando as propriedades do material e, por outro lado, favorecendo o vedamento marginal. Já as ligas com alto conteúdo de cobre (12 a 30\%) possuem melhores características físicas que as convencionais, devido à pouca corrosão que sofrem, causada pela ausência ou pela pequena quantidade de fase gama $2^{41,62,94,102}$. Portanto, essa liga produz um vedamento marginal menos evidente, o que pode aumentar o risco de microinfiltração

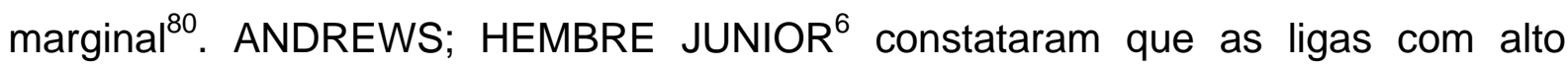
conteúdo de cobre permitem maior microinfiltração marginal e demoram cerca de 2 anos para promover um vedamento semelhante ao obtido com as ligas convencionais.

Com o intuito de prevenir a microinfiltração marginal inicial, enquanto não ocorre o depósito dos produtos de corrosão, a aplicação do verniz cavitário nas paredes do preparo tornou-se um procedimento rotineiro antes da condensação de todos os tipos de liga de amálgama ${ }^{2,4,14,68,83}$. Alguns estudos ${ }^{47,71,98}$ relatam que 0 verniz reduz significantemente a microinfiltração a curto prazo, em média até 6 meses, quando este vedamento inicial é perdido devido a sua dissolução no meio bucal $^{66,83}$, sendo então substituídos pelos produtos da corrosão.

Já em 1897, tentou-se aderir o amálgama às paredes cavitárias, através da aplicação de cimento de fosfato de zinco antes da condensação do material ${ }^{96}$. Porém, somente a partir de 1986 foram realizados mais estudos sobre o assunto, inicialmente com VARGA; MATSUMURA; MASUHARA ${ }^{105}$. Estes autores relataram uma nova técnica restauradora que associava adesivos dentinários ao amálgama dentário, como uma alternativa ao verniz cavitário, com o intuito de promover uma resistência de união e diminuir a microinfiltração marginal. Vários trabalhos in vitro $^{7,19,21,53,67}$ têm mostrado que os adesivos dentinários, usados sob restaurações de amálgama, diminuem a microinfiltração marginal quando comparados ao verniz. Além disso, esta associação apresenta outras vantagens, como diminuição da 
sensibilidade pós-operatória e conservação de estrutura dentária, já que minimiza a necessidade de retenções adicionais ${ }^{45}$.

Existem, atualmente, os adesivos dentinários de componente único, nos quais o "primer" e o adesivo estão presentes em um mesmo frasco. Trabalhos recentes têm demonstrado que esses materiais possuem uma resistência de união à dentina $^{35,87}$ e uma profundidade de microinfiltração marginal ${ }^{39,54}$ semelhante aos sistemas adesivos mais antigos.

Um outro material que vem sendo utilizado em associação ao amálgama é o cimento de ionômero de vidro (CIV), que possui um papel importante na prevenção da cárie dentária secundária, principalmente por possuir a capacidade de liberar íons flúor. Além disso, este material possui outras vantagens, como a adesão química à estrutura dentária e o coeficiente de expansão térmica linear semelhante ao do tecido dentário, que poderiam reduzir a microinfiltração marginal ${ }^{1,3,69,74}$.

A avaliação da microinfiltração marginal entre materiais restauradores e a estrutura dentária pode ser realizada através de estudos in vivo ou in vitro. Este é o mais utilizado, apesar de não haver a influência da pressão hidrostática do fluído dentinário, das interações bioquímicas complexas inerentes a uma placa dentária cariogênica, das constantes alterações térmicas e dos repetidos esforços mastigatórios sobre a restauração, conseguidos em estudos in vivo. A microinfiltração marginal em restaurações adesivas geralmente é determinada através de estudos in vitro, sendo o uso de corantes a técnica mais empregada ${ }^{51,101}$. Estes testes permitem uma avaliação da capacidade de vedamento dos materiais restauradores na interface dente-restauração.

Devido à constante e crescente evolução de técnicas e materiais restauradores, é importante que os mesmos sejam avaliados in vitro inicialmente, para que se tenha uma noção do seu comportamento in vivo. Assim, é possível manifestar-se com maior segurança a respeito de alguns aspectos de importância clínica, antes de se posicionar contra ou a favor de qualquer técnica e/ou sistema restaurador proposto pela literatura. Além disso, um aspecto fundamental inerente à Odontopediatria é a praticidade de uso dos materiais, já que o tratamento restaurador em crianças deve ser efetivo e rápido. A restauração deve preservar a integridade marginal e suportar os esforços mastigatórios da região posterior, além de ser realizada rapidamente, com passos operatórios simples. 
O estudo da associação do amálgama aos adesivos dentinários de componente único e aos CIV, com uso já consagrado em crianças, é justificado e vai ao encontro dos objetivos de um tratamento odontopediátrico, além de ser uma tentativa de melhorar a qualidade de um procedimento restaurador relativamente simples, de custo não elevado e de ampla aplicabilidade clínica. 
2 Revisão de Literatura 


\section{REVISÃO DE LITERATURA}

A microinfiltração marginal em restaurações tem sido um dos aspectos mais pesquisados na Odontologia nos últimos 25 anos, já que ela está relacionada com o fracasso do tratamento, devido a lesões cariosas secundárias, descoloração dentária ao redor da restauração, hipersensibilidade pós-operatória, alterações pulpares e aceleração da degradação ou fratura de materiais forradores. Por se tratar de um tema ainda atual e bastante extenso, a descrição da literatura a seguir foi subdividida em tópicos relativos aos materiais e alguns parâmetros da metodologia empregados neste trabalho.

\subsection{MICROINFILTRAÇÃO MARGINAL COM VERNIZ CAVITÁRIO}

Em 1975, ANDREWS; HEMBRE JUNIOR ${ }^{4}$ compararam in vitro a infiltração marginal em restaurações de amálgama realizadas com três diferentes tipos de liga: Velvalloy (convencional), Spheralloy (convencional esférica) e Dispersalloy (fase dispersa). Foram realizadas cavidades classe $V$ em caninos e prémolares, os quais foram divididos em 6 grupos, diferindo na liga usada e na aplicação ou não de verniz cavitário (Copalite). Após a realização das restaurações, os dentes foram armazenados em solução salina e a infiltração marginal foi verificada nos períodos de 48 horas, 3, 6 e 12 meses, com a utilização de solução de isótopo de $\mathrm{Ca}^{45}$ e auto-radiografias, classificando a infiltração marginal ocorrida através de escores. Foi observada uma intensa infiltração marginal nas restaurações com liga esférica sem verniz nos períodos de 48 horas, 3 e 6 meses, havendo uma diminuição após 12 meses. As restaurações com liga convencional e verniz cavitário não apresentaram infiltração marginal em todos os períodos testados, exceto aos 12 meses, já que uma restauração apresentou leve infiltração. Já as restaurações com liga de fase dispersa sem verniz apresentaram infiltração intensa após 48 horas e moderada nos outros períodos. Porém, com a aplicação prévia de verniz cavitário não houve infiltração marginal, exceto aos 12 meses, quando ela foi leve. Os autores concluíram que, aparentemente, a resistência à corrosão das ligas de fase dispersa 
não aumentou a infiltração marginal, quando comparada com ligas convencionais ou esféricas. Também observaram que a realização da restauração sem aplicação de verniz cavitário aumentou significantemente a infiltração em todos os intervalos, havendo alguma redução somente após 6 meses.

Num estudo em cães, realizado em 1978 por ANDREWS; HEMBREE JUNIOR $^{5}$, foi avaliada a infiltração marginal em restaurações de amálgama realizadas com duas ligas convencionais (Aristaloy e Spheraloy) e duas com alto conteúdo de cobre (Dispersalloy e uma experimental superfina). Preparos classe V foram realizados nos caninos e $4^{\circ}$ pré-molares superiores e inferiores de cada cão e o verniz cavitário Copalite foi aplicado em apenas metade das restaurações. Os dentes foram extraídos após 24 horas, 3 e 6 meses, armazenados por 2 horas em solução de isótopo $\mathrm{Ca}^{45}$, sendo que posteriormente foram obtidas auto-radiografias para avaliação da infiltração marginal, classificada de acordo com escores. Todas as restaurações realizadas sem aplicação de verniz cavitário apresentaram penetração do radioisótopo em nível moderado ou severo após 24 horas e 3 meses, diminuindo para leve ou nenhuma penetração após 6 meses, exceto para um espécime de Aristaloy. Já as restaurações com verniz cavitário apresentaram infiltração marginal ausente ou leve, com exceção de dois espécimes que apresentaram grau moderado. Os autores não observaram diferença na infiltração marginal em relação ao tipo de liga empregada.

Uma avaliação in vitro de diferentes tipos de ligas de amálgama quanto à infiltração marginal foi desenvolvida por ANDREWS; HEMBREE JUNIOR ${ }^{6}$, em 1980. Empregaram ligas de amálgama com alto conteúdo de cobre (Micro II, Optaloy II, Dispersalloy, Sybraloy, Cupralloy, Aristaloy CR, Indiloy e Tytin), comparando-as com uma convencional (Velvalloy). Os testes foram realizados em 270 caninos e prémolares humanos extraídos, sendo que neles foram feitas restaurações classe $V$ sem a aplicação de verniz cavitário. Os dentes foram submetidos à termociclagem em água nas temperaturas de $4^{\circ} \mathrm{C}$ e $58^{\circ} \mathrm{C}$, permanecendo por 1 minuto em cada banho, num total de 100 ciclos. Posteriormente, foram armazenados por 2 horas em solução de $\mathrm{Ca}^{45}$ e seccionados para obtenção de auto-radiografias. A infiltração marginal foi medida nos períodos de 1 dia, 3, 6, 12 ,18 e 24 meses, seguindo uma escala de escores. A liga convencional apresentou grande infiltração até o período de 6 meses, apresentando uma diminuição aos 12 e 18 meses, até a ausência aos 24 meses em quase todos os espécimes. Já com as ligas com alto conteúdo de 
cobre foi observada uma substancial infiltração até os 18 meses, com uma redução significativa aos 24 meses, sendo semelhante às ligas convencionais.

Um estudo da efetividade de vários vernizes cavitários (Copalite, CaviLine, Balsamic's azul, S.S. White Cavity Varnish) na redução da microinfiltração marginal em restaurações de amálgama foi desenvolvido por MURRAY; YATES; WILLIAMS $^{68}$, em 1983. Eles realizaram um experimento in vitro com 200 dentes humanos extraídos, nos quais foram preparadas cavidades classe V. Os dentes foram divididos em 7 grupos, sendo um para cada verniz, outro em que foi aplicada uma solução fluoretada e dois grupos controles, sem aplicação de qualquer material intermediário. Após a realização das restaurações (Dispersalloy), as amostras foram armazenadas em água a $37^{\circ} \mathrm{C}$ por 24 horas, 7 dias, 3 e 6 meses antes de sofrerem termociclagem por 100 ciclos nas temperaturas de $4^{\circ} \mathrm{C}$ e $58^{\circ} \mathrm{C}$, com 1 minuto em cada banho. A microinfiltração marginal foi avaliada através do isótopo radioativo $\mathrm{Ca}^{45}$, através do qual foram obtidas auto-radiografias dos espécimes. Nos grupos controle, observou-se uma profundidade de microinfiltração de moderada a severa após 24 horas e baixa após 6 meses. Entre os vernizes cavitários, o Copalite apresentou melhor vedamento marginal, com pequena ou nenhuma infiltração em todos os períodos observados. O Cavi-Line mostrou bom vedamento marginal inicial, piorando seus resultados até o período de 6 meses. Já os outros vernizes não se diferenciaram do grupo controle. Em todos os grupos, com exceção do Copalite, houve uma redução da microinfiltração marginal entre 3 e 6 meses, provavelmente devido à deposição de produtos da corrosão. Pela homogeneidade dos resultados, o verniz Copalite é o mais indicado para minimizar a microinfiltração marginal em restaurações de amálgama.

Num estudo in vitro semelhante ao anterior, NEWMAN ${ }^{71}$, em 1984, realizou cavidades classe $\mathrm{V}$ em dentes humanos, com o intuito de testar os vernizes Handeliner, Neutraseal, Cavity Lining Varnish (fórmula antiga), Cavity Lining Varnish (fórmula nova) e Copalite. O verniz foi aplicado em duas camadas através de um pincel, sendo que a primeira camada foi seca por 5 minutos antes da aplicação da segunda, que também foi seca pelo mesmo tempo antes da condensação do amálgama (Tytin). Todas as restaurações foram mantidas em solução de $\mathrm{NaCl} a$ $0,9 \%$ por 24 horas a $37^{\circ} \mathrm{C}$ e termocicladas nas temperaturas de $4^{\circ} \mathrm{C}$ e $60^{\circ} \mathrm{C}$, permanecendo 60 segundos em cada banho, num total de 100 ciclos. Após este procedimento, os dentes foram expostos ao isótopo $\mathrm{Ca}^{45}$ para exame da 
microinfiltração marginal, realizado através de escores. Apenas o verniz Neutraseal apresentou um comportamento semelhante ao Copalite. Além disso, foi realizada uma comparação entre a efetividade dos vernizes Copalite e Varnal (diluído em solvente nas concentrações de $75 \%, 50 \%, 25 \%$ e apenas solvente), aplicados em uma ou duas camadas e restaurados com o amálgama Tytin. Também foram feitas restaurações com o amálgama Velvalloy, sem aplicação de verniz, para comparação dos resultados. Observou-se que o verniz Varnal, em concentrações de 50\% e 75\%, apresentou comportamento semelhante ao Copalite, sendo que a aplicação de duas camadas forneceu melhores resultados. A utilização de Copalite ou Varnal a 50\% foram eficazes na redução microinfiltração marginal com ambas as ligas, convencional e esférica.

Neste mesmo ano, também com o objetivo de comparar a efetividade de diferentes vernizes cavitários, SNEED; HEMBRE JUNIOR; WELSH ${ }^{98}$ realizaram 80 cavidades classe $V$ em molares humanos extraídos, os quais foram restaurados com a liga Tytin. Os grupos testados foram Cavi-line, Copalite e S.S. White Cavity Varnish, além de um grupo controle (somente amálgama). Foram utilizados 20 dentes em cada um, os quais foram divididos em 4 subgrupos de 5 dentes cada, já que foram testados diferentes períodos de armazenagem (1 semana, 3, 6 e 12 meses). Antes dos testes, os dentes foram termociclados em água nas temperaturas de $4^{\circ} \mathrm{C}$ e $58^{\circ} \mathrm{C}$, permanecendo 60 segundos em cada banho, num total de 100 ciclos. A microinfiltração marginal foi medida por escores, através da penetração do isótopo $\mathrm{Ca}^{45}$ e obtenção de auto-radiografias. Os autores observaram que o grupo controle apresentou grande microinfiltração marginal após uma semana, o que sugere que ela ocorreu imediatamente, podendo ter uma duração prolongada, já que aos 3, 6 e 12 meses todos os dentes apresentavam também o grau máximo de penetração do isótopo. O verniz S.S. White Cavity Varnish apresentou os piores resultados, sendo até semelhantes ao grupo controle. Aos 6 meses, o verniz Caviline promoveu um vedamento marginal, o que não foi observado após 12 meses, já que ele permitiu microinfiltração marginal máxima. O verniz Copalite apresentou os melhores resultados, pois promoveu um bom vedamento marginal até por um ano.

Também em 1984, FANIAN; HADAVI; ASGAR $^{40}$ estudaram in vitro a influência da aplicação de verniz cavitário (Copalite) e da brunidura pós-escultura na microinfiltração marginal em restaurações de amálgama, realizadas com as ligas Fine-Cut e Spherical (convencionais) e Tytin e Dispersalloy (alto conteúdo de cobre). 
A microinfiltração marginal foi avaliada quantitativamente através da utilização de ar pressurizado (argônio). Para isso, cilindros de plástico foram usados como moldes para condensação de amálgama em seu interior. O gás foi forçado por um período de 15 minutos entre o molde e o amálgama e a quantidade penetrada na interface é que indicou a quantidade de microinfiltração marginal. Para avaliar o efeito do verniz cavitário, foram confeccionados 72 espécimes no total, sendo 18 de cada liga, divididos em 3 grupos de 6 espécimes: grupo 1 - sem verniz; grupo 2 - aplicação de uma camada; grupo 3 - aplicação de duas camadas intercalas por secagem. $O$ verniz foi aplicado com pincel e o amálgama condensado manualmente e esculpido, sendo os espécimes armazenados por 24 horas a $37^{\circ} \mathrm{C}$ para posterior avaliação da microinfiltração. Para avaliação do efeito da brunidura não foi aplicado o verniz cavitário e as 4 ligas também foram utilizadas, sendo confeccionados 6 espécimes para cada liga. Imediatamente após a condensação e escultura, a brunidura foi realizada com um instrumento esférico de $2 \mathrm{~mm}$ de diâmetro, com movimentos do centro da restauração para as margens da cavidade, até a obtenção de uma superfície brilhante. Em seguida, os espécimes foram armazenados pelo mesmo tempo e na mesma temperatura já citadas para posterior realização do teste de microinfiltração marginal. A aplicação de uma, mas sobretudo de duas camadas de verniz, reduziu significantemente a microinfiltração para todas as ligas. A liga FineCut permitiu maior penetração do gás do que as outras ligas na ausência de verniz, porém não houve diferença entre ela e as outras quando pelo menos uma camada foi aplicada. A realização de brunidura pós-escultura reduziu a microinfiltração marginal de maneira significativa com todos as ligas, sem diferença entre elas.

Em 1985, BEN-AMAR et al. ${ }^{16}$ examinaram o efeito da combinação de dois tipos de verniz cavitário (Copalite e Caviline) e duas bases de hidróxido de cálcio (Dycal e Life) na microinfiltração marginal de restaurações de amálgama (Permite C). Foram utilizados 49 molares ou pré-molares humanos extraídos, que receberam cavidades classe $\mathrm{V}$ nas faces vestibular e lingual, com todas as margens em esmalte. As cavidades foram divididas em 7 grupos: controle - somente amálgama; grupo I - Dycal + Caviline; grupo II - Life + Caviline; grupo III - Dycal + Copalite; grupo IV - Life + Copalite; grupo V - Caviline; grupo VI - Copalite. O cimento de hidróxido de cálcio foi aplicado somente na parede axial e, 7 minutos depois, o verniz foi pincelado em duas camadas e seco por 5 segundos com um leve jato de ar. Após a realização das restaurações, os dentes foram termociclados em solução 
de fucsina básica a $0,5 \%$, nas temperaturas de $4^{\circ} \mathrm{C}$ e $60^{\circ} \mathrm{C}$, em banhos de 60 segundos, por 100 ciclos. Posteriormente, os dentes foram mantidos na mesma solução por 14 dias, seccionados e examinados em microscópio com um aumento de 16 vezes, sendo que as paredes oclusal e gengival foram avaliadas separadamente. O grupo controle apresentou os piores resultados, já que todos os espécimes tiveram o pior escore de microinfiltração marginal. Os vernizes diminuíram significantemente a penetração do corante. A combinação de verniz cavitário e cimento de hidróxido de cálcio apresentou resultados piores que o uso de verniz somente, porém com um comportamento melhor que o grupo controle. Dentre as diferentes combinações, o uso de Life e Copalite teve menor escore de microinfiltração. Os autores concluíram que o verniz não deve se aplicado diretamente sobre a base de hidróxido de cálcio, mas somente nas paredes em que este material não estiver presente.

Também em 1985, SILVA et al. ${ }^{97}$ estudaram, in vitro, o efeito da associação entre bases forradoras de óxido de zinco e eugenol reforçado (B \& $T$ ), cimento de hidróxido de cálcio (Dycal) e verniz cavitário (Copalite) na microinfiltração marginal de restaurações de amálgama (Dispersalloy). Foram utilizados 110 dentes humanos extraídos e hígidos, nos quais foram realizados preparos classe $\mathrm{V}$ no centro da face vestibular. Estes dentes foram divididos aleatoriamente em 4 grupos, sendo que os três primeiros possuíam 28 dentes enquanto o grupo IV continha 26 dentes: grupo I - verniz cavitário; grupo II - cimento de hidróxido de cálcio e verniz cavitário; grupo III - óxido de zinco e eugenol reforçado e verniz cavitário; grupo IV somente amálgama. Os materiais foram manipulados de acordo com as instruções do fabricante, inseridos na cavidade e o verniz aplicado em duas camadas, com bolinhas de algodão. Cada grupo foi subdividido em 4 subgrupos de acordo com o tempo de estocagem: 48 horas, 1 e 3 meses, com posterior ciclagem térmica e mecânica; 48 horas sem ciclagem. A ciclagem térmica foi realizada em água, nas temperaturas de $15^{\circ} \mathrm{C}$ e $50^{\circ} \mathrm{C}$, durante 1000 ciclos, com banhos de 90 segundos. Posteriormente, os dentes sofreram ciclagem mecânica, que consistiu na realização de 1000 ciclos de carga e descarga, já que em cada ciclo a força era aumentada a um máximo de $20 \mathrm{lb}$ e depois era diminuída a zero. Os dentes foram armazenados em uma solução de azul de metileno a $0,1 \%$ por 24 horas, a $37^{\circ} \mathrm{C}$, seccionados ao meio e a restauração de amálgama foi removida da hemicavidade. As análises foram realizadas por dois métodos: estereomicroscópio de luz refletida, num aumento de 
30 vezes (medida linear) e por espectrofotometria (medida volumétrica). Para a avaliação microscópica foi considerada somente a metade da cavidade com maior microinfiltração, o que foi observado a olho nu. Nela, foi medida a distância do ponto de penetração mais profundo do corante, o que foi realizado sempre por um único examinador. Já o exame de espectrofotometria considerou as duas metades do dente. O primeiro exame demonstrou que o grupo II apresentou uma microinfiltração marginal significantemente maior que os demais grupos, quando não foi realizado o procedimento de ciclagem. Com a ciclagem, no período de um mês, somente o grupo IV apresentou maior microinfiltração do que o grupo I, sendo a diferença estatisticamente significante. Na avaliação pela espectrofotometria, observou-se uma grande variação das medidas obtidas, sendo que os resultados foram semelhantes às medidas lineares. Através deste exame também se observou que o grupo II apresentou maior microinfiltração marginal que os grupos I e III após 48 horas, na ausência de ciclagem. Houve uma correlação positiva entre os dois métodos de análise.

Em 1986, NEWMAN; SZOJKA ${ }^{72}$ analisaram o padrão de microinfiltração marginal em restaurações de amálgama classe $\mathrm{V}$ ao longo do tempo. Foram utilizadas 3 ligas diferentes: Tytin (esférica com alto conteúdo de cobre), Dispersalloy (mista com alto conteúdo de cobre) e Velvalloy (convencional), sendo que em metade da amostra foram aplicadas duas camadas do verniz cavitário Copalite. Os dentes foram armazenados em água destilada a $37^{\circ} \mathrm{C}$ e termociclados em banhos de $4^{\circ} \mathrm{C}$ e $60^{\circ} \mathrm{C}$ por 100 ciclos. A termociclagem foi realizada 24 horas após a restauração e a cada 2 semanas até 6 meses. Após cada termociclagem, 10 espécimes de cada grupo eram armazenados em solução de isótopo $\mathrm{Ca}^{45}$ para a obtenção de auto-radiografias. As amostras sem verniz sofreram uma redução da microinfiltração marginal de severa para leve após 6 a 8 semanas. Com a aplicação do verniz, ambas as ligas com alto conteúdo de cobre apresentaram um aumento da microinfiltração marginal, com um pico na 6르 semana, decrescendo novamente. Os autores concluem que a suposição de que o verniz cavitário seria eficaz na detenção da microinfiltração marginal em restaurações com ligas de alto conteúde de cobre pode ser questionável.

Num estudo in vitro, BEN-AMAR et al. ${ }^{17}$, em 1986, avaliaram o efeito do número de aplicações de verniz cavitário (Copalite) na microinfiltração marginal em restaurações de amálgama realizadas com diferentes ligas (Tytin - esférica com alto 
conteúdo de cobre; Silmet - limalha convencional; Permite C - fase dispersa). Cada grupo foi dividido em 3 subgrupos: A: sem verniz; B: aplicação de uma camada; C: aplicação de duas camadas. Para isso, foram utilizados 125 pré-molares ou molares humanos extraídos, que receberam cavidades classe $V$ nas faces vestibular e lingual, com todas as margens em esmalte. O verniz foi aplicado com bolinhas de algodão e seco por jatos de ar por 10 segundos com um leve jato de ar, o amálgama condensado manualmente e as restaurações foram esculpidas, mas não brunidas. Os dentes foram submetidos à termociclagem em solução de fucsina básica a 0,5\% em temperaturas de $4^{\circ} \mathrm{C}$ e $60^{\circ} \mathrm{C}$, por 30 segundos, num total de 25 ciclos. Posteriormente, os dentes foram armazenados na mesma solução por 3 semanas, a uma temperatura de $37^{\circ} \mathrm{C}$. Os dentes foram seccionados e os espécimes avaliados em microscópio de luz, com um aumento de 16 vezes, e classificados de acordo com escores. Com as ligas Tytin e Silmet, a aplicação de duas camadas reduziu a microinfiltração significantemente. Já com a liga Permite $C$, não houve diferença nos três subgrupos. Quando as ligas foram comparadas entre si, houve diferença estatisticamente significante entre o Tytin (pior resultado) e Permite C (melhor resultado). Esta diferença na microinfiltração marginal entre ligas esferoidais e ligas de fase dispersa ou limalha pode ocorrer pela melhor adaptabilidade destas às paredes cavitárias, além de estarem na dependência da condensação realizada, manipulação do material, plasticidade do amálgama e realização de brunidura.

Um dos fatores negativos da utilização de verniz cavitário sob restaurações de amálgama é a sua desintegração. Em 1987, com o intuito de avaliar este processo, POWELL; DAINES ${ }^{83}$ realizaram dois estudos in vitro, com metodologias diferentes. No primeiro estudo, foram testados 3 vernizes: Copalite (verniz copal), Cavi-line e Universal (vernizes não copais). Foram utilizadas duas soluções para avaliar a desintegração dos vernizes: solução salina e solução de Ringer. Nestas soluções, amostras de vidro cobertas com verniz foram imersas por 7 dias. Através da diferença entre os pesos das amostras antes e depois da imersão pôde-se calcular a desintegração do verniz. No segundo estudo, o verniz Universal foi marcado com o isótopo $\mathrm{C}^{14}$, com a colaboração do fabricante. Foram preparados 10 espécimes com uma quantidade conhecida de verniz e, posteriormente, os mesmos foram armazenados em uma solução, na qual era possível medir a desintegração do verniz. Da mesma maneira, 10 espécimes foram armazenados nas soluções usadas no primeiro estudo, por um período de 7 dias, sendo que após este 
tempo também foram submetidos à desintegração. O verniz cavitário marcado e dissolvido na solução de imersão também foi estudado, para a determinação da quantidade total de verniz desintegrado. Os autores observaram que todos os vernizes se desintegraram, perdendo peso após um período de 7 dias. Porém, estes estudos foram realizados com o verniz completamente exposto à solução, enquanto na cavidade bucal este material permanece protegido pela estrutura dentária e pelo material restaurador. Segundo os autores, embora este material se desintegre com o tempo, ele ainda deve ser utilizado sob restaurações de amálgama com o intuito de reduzir a microinfiltração marginal inicial, reduzir a sensibilidade pós-operatória e auxiliar na proteção da dentina pelo tempo que for possível.

Em 1988, KELSEY; PANNETON ${ }^{50}$ compararam a microinfiltração marginal em restaurações de amálgama protegidas com verniz copal (Copalite) e dois vernizes resinosos (Cavi-Line e Barrier), em um estudo in vitro. Foram utilizados 40 molares, os quais receberam cavidades classe $\mathrm{V}$ com todas as margens em esmalte. Os dentes foram divididos em 4 grupos: I - amálgama somente; II Copalite e amálgama; III - Barrier e amálgama; IV - Cavi-Line e amálgama. O verniz foi aplicado em duas camadas, seguidas por um leve jato de ar, e os dentes foram restaurados com a liga Dispersalloy. Todos os grupos foram termociclados por 24 horas nas temperaturas de $5^{\circ} \mathrm{C}$ e $55^{\circ} \mathrm{C}$, com 60 segundos de imersão e um intervalo de 12 segundos entre os banhos, em temperatura ambiente. Após este procedimento, os dentes foram armazenados em água por 24 horas, imersos em solução de cristal de violeta a $0,05 \%$ por 4 horas, lavados e seccionados no centro das restaurações. A avaliação foi realizada com um microscópio de reflexão de luz com aumento de 20 vezes, sendo que somente a secção do dente com maior microinfiltração era examinada para obtenção do escore. O uso do verniz cavitário reduziu significantemente a microinfiltração marginal quando comparado ao grupo sem verniz e os melhores resultados foram obtidos no grupo em que o Copalite foi aplicado.

Em 1990, com o intuito de avaliar a microinfiltração marginal em restaurações de amálgama (Tytin) protegidas com dois diferentes vernizes cavitários (Copalite e Barrier), FITCHIE et al. ${ }^{41}$ realizaram um estudo in vitro, usando 54 molares humanos extraídos que receberam cavidades classe I. Estes foram divididos em 3 grupos: I - sem verniz; II - Copalite; III - Barrier. Foram aplicadas duas camadas do verniz em todas as paredes das cavidades, inclusive no ângulo 
cavossuperficial, antes da condensação do amálgama. Cada grupo foi dividido em 3 subgrupos de 6 dentes, de acordo com o tempo de armazenagem dos espécimes em água a $37^{\circ} \mathrm{C}$ ( 1 semana, 6 meses e 12 meses). Os dentes foram termociclados em água nas temperaturas de $4^{\circ} \mathrm{C}$ e $58^{\circ} \mathrm{C}$, com um minuto em cada banho, num total de 100 ciclos. A microinfiltração marginal foi observada através da penetração do isótopo $\mathrm{Ca}^{45}$ e obtenção de auto-radiografias, sendo analisada por escores. $\mathrm{O}$ uso do verniz cavitário reduziu significantemente a microinfiltração marginal imediata nas restaurações de amálgama. Aos 6 meses, o verniz Copalite apresentou melhor comportamento, já que permitiu penetração mínima do isótopo enquanto o verniz Barrier permitiu microinfiltração marginal grosseira. Resultado semelhante foi encontrado em todos os 3 grupos após 12 meses.

$\mathrm{Na}$ tentativa de avaliar a capacidade vedadora de vernizes terapêuticos aplicados sob restaurações de amálgama, MCCOMB; BEN-AMAR; BROWN ${ }^{61}$ realizaram um estudo, em 1990, em cavidades classe $V$ confeccionadas nas faces vestibular e lingual de 40 molares, com margens localizadas em esmalte. Os vernizes testados foram o Duraflor e Fluorprotector (com flúor) e um experimental com clorexidina, sendo que eles foram comparados ao verniz Copalite. Os dentes foram restaurados com o amálgama Tytin, armazenados em água a $37^{\circ} \mathrm{C}$ por 24 horas e termociclados em água nas temperaturas de $10^{\circ} \mathrm{C}$ e $50^{\circ} \mathrm{C}$, em banhos de 6 segundos, por 1000 ciclos. Posteriormente, os dentes foram imersos em solução de fucsina básica a $0,1 \%$ durante 24 horas e seccionados longitudinalmente para avaliação da microinfiltração marginal com um aumento de 2,5 vezes, tanto na parede oclusal como gengival. Os valores de microinfiltração na parede gengival foram sempre maiores que os encontrados na parede oclusal. Os melhores resultados foram obtidos pelo verniz Duraflor, mas todos os vernizes terapêuticos vedaram a interface dente-restauração igualmente ou até mesmo melhor que o verniz cavitário convencional.

Em 1993, BEN-AMAR; CARDASH; LIBERMAN ${ }^{15}$ avaliaram a influência da técnica de aplicação de dois tipos de verniz cavitário (Copalite e Universal Dentin Sealant) na microinfiltração marginal de restaurações de amálgama (Tytin) classe $V$ com margens em esmalte e cemento, realizadas nas faces vestibular e lingual de 132 molares humanos extraídos. Após a realização dos preparos, eles foram limpos com Tubulicid Red Label. Estes foram divididos em 4 grupos de 30 dentes cada, além de um quinto grupo com 12 dentes. Os grupos foram subdivididos em $A$ e $B$, de 
acordo com as formas e tempos de aplicação do verniz, assim como a maneira de secagem do material: grupo 1-A: duas camadas de Copalite aplicadas com bolinha de espuma e secagem por 30 segundos com leve jato de ar após cada aplicação; grupo 1-B: uma camada de Universal Dentin Sealant aplicado com pincel e secagem por 10 segundos; grupo 2-A: duas camadas de Copalite e secagem por 3 segundos com leve jato de ar após cada aplicação; grupo 2-B: Universal Dentin Sealant na mesma seqüência do grupo 2-A; grupo 3-A: duas camadas de Copalite, sendo que era realizada a secagem imediata por 3 segundos com jato de ar e espera por 30 segundos após cada camada; grupo 3-B: Universal Dentin Sealant na mesma seqüência do grupo 3-A; grupo 4-A: duas camadas de Copalite, com uma espera de 10 segundos, secagem por 3 segundos com jato de ar e espera por mais 30 segundos após cada camada; grupo 4-B: Universal Dentin Sealant na mesma seqüência do grupo 4-A; grupo 5: sem aplicação de verniz (controle). Após a aplicação do verniz, o amálgama foi condensado e a restauração esculpida. Os dentes foram armazenados em água por 48 horas, à $37^{\circ} \mathrm{C}$ e termociclados nas temperaturas de $5^{\circ} \mathrm{C}$ e $55^{\circ} \mathrm{C}$ por 100 ciclos, em banhos de 10 segundos. Em seguida, sofreram ciclagem mecânica de 500 vezes, com cargas de $5 \mathrm{~kg}$ por 0,5 segundo, foram imersos em solução de fucsina básica a 0,5\% por 48 horas e seccionados ao meio no sentido vestíbulo-lingual. A penetração do corante foi avaliada por um microscópio de luz refletida, com um aumento de 16 vezes, e classificado por escores. Nenhum dos dois vernizes foi capaz de reduzir significantemente a microinfiltração marginal na parede gengival, ao contrário do que foi observado na parede oclusal. Quando um tempo de secagem muito curto foi utilizado, ambos os vernizes falharam na prevenção da microinfiltração, talvez pela presença de solvente não evaporado na camada de verniz. A aplicação de Universal Dentin Sealant em uma camada e secagem por 10 segundos promoveu um selamento comparável ou superior a todos os outros grupos nos quais duas camadas foram aplicadas.

Em uma revisão de literatura, $\operatorname{HILTON}^{47}$, em 1996, discutiu os vários materiais protetores, sua interação e proteção promovida sobre o tecido pulpar, assim como suas propriedades e recomendações para o seu uso. O verniz cavitário é uma goma natural ou uma resina sintética dissolvida em solvente orgânico (acetona, clorofórmio, etc), que se evapora para formar um filme protetor. Este material é utilizado para vedar a interface dente-restauração até que os produtos da 
corrosão do amálgama eliminem a fenda marginal, além de promover uma barreira contra a passagem de agentes irritantes dos materiais restauradores. Com a aplicação de duas camadas, ele é capaz de reduzir a permeabilidade dentinária em $69 \%$ e reduzir significantemente a microinfiltração marginal por 6 meses. Como a camada de verniz é muito fina, pouca ou nenhuma proteção térmica é promovida.

\subsection{MICROINFILTRAÇÃO MARGINAL COM MATERIAIS ADESIVOS}

Um dos grandes problemas das restaurações de amálgama é a falta de adesão aos tecidos dentários, o que pode predispor a restauração a fraturas marginais, microinfiltração marginal e cárie secundária. VARGA; MATSUMURA; MASUHARA $^{105}$, em 1986, realizaram um estudo com o objetivo de avaliar os efeitos da utilização de adesivos dentinários na resistência de união e na microinfiltração marginal entre restaurações de amálgama e o tecido dentário. Os materiais utilizados foram os adesivos 4-META/MMA-TTB e Panavia EX, além do amálgama Shofu Spherical D type. Para o teste de microinfiltração foram realizadas cavidades classe I em 10 pré-molares e 15 molares. Os dentes foram divididos em 5 grupos: grupo 1 - somente amálgama; grupo 2 - adesivo 4-META sem ataque ácido; grupo 3 - Panavia EX sem ataque ácido; grupo 4 - ataque prévio com ácido fosfórico aquoso a $65 \%$ durante 30 segundos, lavagem por 5 minutos, secagem, aplicação do adesivo 4-META; grupo 5 - ataque prévio com ácido fosfórico aquoso a $40 \%$ durante 60 segundos, lavagem por 5 minutos, secagem, aplicação de Panavia EX. Nos 3 primeiros grupos foram utilizados os molares e nos outros dois, o pré-molares. Após estes procedimentos, os espécimes foram mantidos em temperatura ambiente por 2 horas, armazenados em solução de fucsina básica a $37^{\circ} \mathrm{C}$ por 1 dia para posterior realização do acabamento e polimento. Em seguida, foram novamente armazenados na solução corante por 1 semana e seccionados em fatias para analisar a penetração do corante. Para o teste de cisalhamento foram utilizados os incisivos centrais, que tiveram a superfície vestibular planificada com lixa 220 e polida com lixa 400 . Foi realizado um ataque ácido da superfície com ácido fosfórico a $65 \%$ por 30 segundos, lavagem por 5 minutos, secagem, aplicação do adesivo e condensação do amálgama. As amostras foram mantidas em temperatura ambiente por 24 horas e depois armazenadas em água por 1 dia e 1 mês a $37^{\circ} \mathrm{C}$ para 
realização dos testes. Quanto ao teste de microinfiltração marginal, no grupo 1 houve penetração do corante em todas as paredes; no grupo 2 ela foi menor que $0,1 \mathrm{~mm}$, envolvendo apenas uma parede; nos demais grupos não se observou penetração do corante. Quanto ao teste de cisalhamento, os resultados foram semelhantes em 1 e 30 dias, apresentando falhas coesivas do adesivo. Após 1 mês, foi possível verificar presença de amálgama aderido em algumas áreas da superfície dentária. Os autores concluíram que a utilização de adesivos reduz a microinfiltração marginal, mas não sabiam afirmar por quanto tempo a ligação adesiva poderia ser mantida.

Ainda em 1987, BEN-AMAR et al. ${ }^{18}$ compararam a efetividade do vedamento marginal do sistema adesivo Scotchbond e do verniz cavitário Copalite em restaurações de amálgama realizadas com Tytin. Foram preparadas cavidades classe $\mathrm{V}$ nas faces mesial e lingual de 44 dentes humanos hígidos, com faces em esmalte e cemento, sendo os dentes divididos em 4 grupos: grupo I - apenas amálgama; grupo II - duas camadas de Copalite; grupo III - condicionamento ácido do esmalte com ácido fosfórico a 37\% por 60 segundos e uma camada de Scotchbond fotopolimerizada por 20 segundos; grupo IV - idem ao grupo III, porém com duas camadas de adesivo. Após termociclagem por 200 ciclos em temperaturas de $4^{\circ} \mathrm{C}$ e $55^{\circ} \mathrm{C}$ em fucsina básica a $0,5 \%$, os espécimes foram mergulhados no mesmo corante por 10 dias a $37^{\circ} \mathrm{C}$. Os dentes foram cortados em duas metades e avaliados visualmente, sendo a penetração do corante classificada em escores. Quando nenhum material intermediário foi usado houve maior infiltração marginal, enquanto os menores resultados foram encontrados com 0 uso do adesivo Scotchbond em duas camadas, o que eliminou a penetração de corante na parede oclusal. Na parede gengival os melhores resultados também foram encontrados com a aplicação de duas camadas de adesivo, seguido pela aplicação de apenas uma camada do mesmo material e pela aplicação de duas camadas de verniz, sendo que este apresentou resultados bem inferiores. Os autores concluíram que "embora esta seja uma nova investigação, não há razão para se acreditar que os resultados in vivo possam ser diferentes".

YU; WEI; XU109, em 1987, avaliaram in vitro a microinfiltração marginal e formação de fendas marginais em restaurações de amálgama de liga convencional associado a cinco agentes adesivos. Foram utilizados 18 molares humanos extraídos, os quais receberam cavidades classe $V$ nas faces vestibular e lingual com 
as margens localizadas em esmalte. Os dentes foram divididos em 6 grupos, de acordo com o adesivo aplicado (EB unfilled resin; Dentin Adhesive; EM bonding agent; Creation bonding agent; New Bond bonding agent e Prisma Universal Bond), e um grupo controle (sem tratamento prévio). Após a confecção das restaurações, os dentes foram termociclados em corante azul de metileno por 100 ciclos nas temperaturas de $4^{\circ} \mathrm{C}$ e $60^{\circ} \mathrm{C}$, com banhos de 120 segundos. Posteriormente, foram seccionados no sentido vestíbulo-lingual para avaliação da microinfiltração marginal nas paredes gengival e oclusal através de um microscópio óptico de 12 vezes de aumento, seguindo um critério de escores. Para a avaliação da fenda marginal, as amostras foram submetidas a um processo de termociclagem em banhos de 60 segundos em nitrogênio líquido a $-190^{\circ} \mathrm{C}$ e água quente a $40^{\circ} \mathrm{C}$, por 40 ciclos. $\mathrm{O}$ grupo controle apresentou os piores resultados de microinfiltração marginal, tanto na parede gengival como na oclusal. Nos grupos experimentais houve uma grande redução na penetração do corante, mais evidente na parede gengival. Dentre todos os grupos experimentais, os melhores resultados foram obtidos com o Creation bonding agent e os piores com o Prisma Universal Bond. Na análise por M.E.V., observou-se uma fenda marginal de aproximadamente $5 \mu \mathrm{m}$ no grupo controle, enquanto nos grupos experimentais o adesivo foi capaz de preenchê-la.

Em 1988, STANINEC; HOLT ${ }^{99}$ avaliaram a força de adesão e o vedamento marginal em restaurações adesivas de amálgama, testando o cimento resinoso Panavia EX e um verniz copal com a liga Tytin. Para o teste de microinfiltração marginal foram utilizados 20 molares humanos extraídos, nos quais cavidades classe $V$ foram realizadas em faces opostas, sendo uma margem em cemento e a outra em esmalte. No grupo 1 foi aplicado o cimento resinoso em uma cavidade e verniz copal na outra, enquanto no grupo 2 foi aplicado o cimento resinoso de uma lado e nenhum material forrador no outro. Todos os espécimes foram armazenados por 24 horas em água, termociclados por 100 ciclos de $4^{\circ} \mathrm{C}$ e $60^{\circ} \mathrm{C}$, mantidos em fucsina básica por uma noite e seccionados no centro da restauração para avaliação em um estereomicroscópio, classificando a penetração do corante por escores pré-estabelecidos. No teste de força adesiva, a superfície oclusal foi planificada com lixa 600 e os dentes foram montados em um dispositivo da máquina de ensaios Universal que permitia a condensação do amálgama sobre os dentes, sendo testados o cimento resinoso Panavia EX e o verniz copal. Os melhores resultados de microinfiltração foram obtidos pelo uso do cimento resinoso, 
porém sem diferença estatisticamente significante, na parede gengival, quando comparado ao verniz copal. Nos testes de tração, foi obtida uma força de união de 1404 psi e de 469 psi quando o cimento resinoso foi utilizado no esmalte e na dentina, respectivamente. No grupo do verniz, a força de união obtida foi menor que 17 psi tanto para o esmalte como para a dentina. Através de um exame microscópio das superfícies fraturadas, parecia haver falhas na interface resina-amálgama nas amostras em esmalte e na interface resina-dentina nas amostras em dentina.

O cimento de ionômero de vidro (CIV) surgiu da combinação das vantagens do pó do cimento de silicato com as do líquido do cimento de policarboxilato, tendo sido apresentado à comunidade científica em 1971. Em 1988, WILSON; McLEAN ${ }^{107}$ publicaram um livro onde discutem a composição, propriedades, aspectos estéticos e a biocompatibilidade do material, além de outros aspectos, divulgando amplamente esse material e suas aplicaçòes na Odontologia. Dentre suas boas propriedades, devem ser destacados a biocompatibilidade, a capacidade de adesão química aos tecidos dentários, liberação de flúor e módulo de elasticidade semelhante à estrutura dentária.

Em 1989, TORII et al. ${ }^{103}$ avaliaram a capacidade de inibição de cárie em restaurações de amálgama realizadas com ou sem o uso de um cimento resinoso (Panavia EX). Foram preparadas cavidades classe $V$ nas faces vestibular e lingual de 14 molares humanos extraídos, sendo a parede cervical em cemento e a parede oclusal em esmalte. No grupo experimental, os dentes foram preparados e as cavidades condicionadas com ácido fosfórico a 37\% por 30 segundos em todas as paredes, lavadas por 20 segundos, secas por 30 segundos e, em seguida, o cimento resinoso Panavia EX foi aplicado de acordo com as instruções do fabricante. No grupo controle, as cavidades foram lavadas com água por 20 segundos, secas por 30 segundos e restauradas com amálgama, sem a aplicação de qualquer material intermediário. Os dentes de ambos os grupos foram estocados por 24 horas a $37^{\circ} \mathrm{C}$ e termociclados por 100 ciclos nas temperaturas de $4^{\circ} \mathrm{C}$ e $60^{\circ} \mathrm{C}$, em banhos de 2 minutos. Após o selamento dos dentes para que apenas as margens das restaurações permanecessem expostas, os mesmos foram incubados com Streptococus mutans e sacarose para produção de lesões de cárie artificiais. Posteriormente, os dentes foram seccionados para determinar a penetração da lesão pelas paredes cavitárias, através de microrradiografias avaliadas em um microscópio com aumento de 40 vezes. O cimento resinoso inibiu consideravelmente 
a penetração de lesões de cárie pelas paredes cavitárias se comparado ao grupo sem aplicação deste material, tanto nas margens em cemento como nas margens em esmalte.

Em 1990, MANDERS; GARCIA-GODOY; BARNWELL ${ }^{59}$ avaliaram in vitro a microinfiltração marginal em restaurações de amálgama (Dispersalloy) forradas com verniz cavitário, cimento de óxido de zinco e eugenol melhorado e cimento de ionômero de vidro. Foram utilizados 20 terceiros molares humanos com 2 preparos cavitários classe $V$ nas faces livres, com margens $2 \mathrm{~mm}$ aquém da junção cementoesmalte. Os grupos de estudo foram: I - sem forramento; II - duas camadas de Copalite secas por jato de ar por 10 segundos; III - base de IRM; IV - base de Chelon-Silver, aplicada após tratamento da cavidade com Ketac-Conditioner por 10 segundos, lavagem por 10 segundos e secagem por 5 segundos. Os dentes restaurados foram armazenados em água por 24 horas, polidas as restaurações e novamente armazenados em água por mais 24 horas. Posteriormente, os espécimes foram submetidos à termociclagem nas temperaturas de $5^{\circ} \mathrm{C}$ e $55^{\circ} \mathrm{C}$, com 30 segundos em cada banho, por 100 ciclos, armazenados em solução de fucsina básica a $2 \%$ por 24 horas e seccionados no sentido vestíbulo-lingual em 3 áreas da restauração. Os espécimes foram avaliados em um microscópio com 40x de aumento, sendo que somente o escore mais alto de cada restauração era considerado. As restaurações forradas com Chelon-Silver ou Copalite exibiram uma microinfiltração marginal estatisticamente menor que aquelas sem forramento ou com IRM. Numa comparação entre os materiais de melhor comportamento, observou-se que o CIV teve melhor comportamento, impedindo que o corante penetrasse até a parede axial da cavidade. Houve diferença estatisticamente significante entre os resultados obtidos nas paredes oclusal e gengival dos grupos Chelon-Silver e Copalite, com menor microinfiltração marginal na primeira.

Em 1990, YOUNGSON; GREY; GLYN JONES ${ }^{108}$ estudaram in vitro dois métodos de avaliação da microinfiltração marginal em restaurações de amálgama. Foram utilizados 30 pré-molares humanos extraídos por razões ortodônticas, nos quais foram realizados preparos classe II com término cervical $1 \mathrm{~mm}$ aquém da junção cemento-esmalte. Os dentes foram divididos em 3 grupos: A - aplicação de duas camadas de verniz cavitário (De Trey) em todas as paredes e margens cavitárias; B - aplicação de uma camada fina de Vitrabond nas paredes pulpar e axial e fotopolimerização por 40 segundos; C - pré-tratamento com ácido poliacrílico 
a 40\% por 30 segundos e aplicação de Ketac-Silver em toda a dentina. O amálgama utilizado foi o Ana 2000, uma liga com alto conteúdo de cobre. No grupo C, a condensação foi feita sem que o cimento de ionômero de vidro tivesse tomado presa. Após a escultura, os dentes foram imersos em água deionizada em temperatura ambiente por pelo menos 7 dias. Após 24 horas, o polimento foi realizado e os dentes foram imersos em eosina a $5 \%$ por 48 horas. Após o seccionamento do dente em duas partes, uma delas foi escolhida aleatoriamente e fotografada com um aumento de 2,25 vezes, juntamente com uma escala milimetrada para posterior análise. As imagens eram projetadas com um aumento de 15 vezes por uma programa (Magiscan 2). A avaliação da microinfiltração marginal foi realizada através de dois métodos: comprimento total de penetração do corante e porcentagem de dentina coronária com penetração do corante. Numa comparação entre os grupos, observou-se que o Vitrabond apresentou os menores resultados de penetração de corante, tanto linearmente como em relação à área, enquanto os grupos A e C tiveram resultados semelhantes. Houve correlação entre os métodos de avaliação no grupo A, mas o mesmo não ocorreu com os grupos B e C, já que os mesmos promoviam um melhor selamento da dentina, impedindo a penetração de corante pelos túbulos dentinários.

Em 1990, BEN-AMAR et al. ${ }^{19}$ analisaram in vitro a eficiência de um verniz cavitário convencional (Copalite) e de um adesivo dentinário fotopolimerizável (Scotchbond Dental Adhesive) na redução de microinfiltração marginal em restaurações de amálgama classe II de molares humanos. Foram utilizado 40 dentes, que receberam cavidades nas faces mesial e distal, sendo a margem gengival localizada $1 \mathrm{~mm}$ abaixo da junção amelocementária e a oclusal, em esmalte. As 80 cavidades foram divididas em 3 grupos: grupo 1 (controle) - 16 cavidades restauradas com o amálgama Tytin; grupo 2 - 32 cavidades que receberam a aplicação de duas camadas de verniz cavitário Copalite + amálgama Tytin; grupo 3 32 cavidades que receberam condicionamento ácido do esmalte com ácido fosfórico a $37 \%$ por 60 segundos, lavagem por 30 segundos, secagem e aplicação de duas camadas do adesivo Scotcbond Dental Adhesive, sendo que cada uma foi fotopolimerizada por 20 segundos + Tytin. Todos os dentes foram armazenados em água a $37^{\circ} \mathrm{C}$ por 6 meses. Mensalmente os dentes eram termociclados nas temperaturas de $4^{\circ} \mathrm{C}$ e $55^{\circ} \mathrm{C}$, com banhos de 30 segundos, totalizando 200 ciclos e sofriam cargas oclusais de $6 \mathrm{Kg}$. Ao final do período, os dentes foram novamente 
termociclados, porém em solução de fucsina básica a 0,5\% e armazenados nesta solução por um período de 7 dias, em temperatura de $37^{\circ} \mathrm{C}$. Posteriormente, foram seccionados no sentido mésio-distal através do centro da restauração e avaliados através de um microscópio binocular com aumento de 16 vezes, sendo a penetração do corante classificada de acordo com escores. A aplicação de adesivo dentinário reduziu significantemente a microinfiltração marginal na parede gengival, com melhores resultados se comparado ao grupo em que foi utilizado o verniz cavitário. Os piores resultados foram apresentados pelo grupo controle, o qual permitiu máxima penetração do corante em $75 \%$ dos espécimes. O verniz cavitário permitiu microinfiltração máxima em $45 \%$ das restaurações, enquanto $25 \%$ não apresentou penetração do corante. $\mathrm{O}$ adesivo, por sua vez, não apresentou microinfiltração marginal máxima em nenhum espécime e $40 \%$ deles não permitiu qualquer penetração do corante.

COOLEY; TSENG; BARKMEIER ${ }^{31}$ realizaram um estudo in vitro, em 1991, com o objetivo de analisar a capacidade de adesão à dentina do adesivo Amalgambond 4-Meta associado a uma resina composta (Bis-Fil), a uma liga de amálgama de fase dispersa (Dispersalloy) e a uma liga esférica (Valiant), além de estudar a capacidade de vedamento marginal deste mesmo adesivo, comparando-o com o verniz cavitário Caviline em restaurações de amálgama (Dispersalloy). Para o teste de adesão, foram utilizados 80 molares que tiveram sua superfície vestibular preparada com lixa 600, sendo que o adesivo Amalgambond 4-Meta foi aplicado na dentina. Os dentes foram divididos igualmente em 4 grupos: grupo 1 - resina composta Bis-Fil e estocagem em água destilada a $37^{\circ} \mathrm{C}$ por 24 horas; grupo 2 resina composta Bis-Fil, armazenagem por 24 horas e termociclagem por 24 horas (800 ciclos), em temperaturas de $6^{\circ} \mathrm{C}$ e $60^{\circ} \mathrm{C}$, com 30 segundos em cada banho; grupo 3 - Dispersalloy e estocagem em água destilada a $37^{\circ} \mathrm{C}$ por 24 horas; grupo 4 - Valiant e estocagem em água destilada a $37^{\circ} \mathrm{C}$ por 24 horas. Após este período, os testes foram realizados com uma máquina Instron, com cargas de $5 \mathrm{~mm} / \mathrm{min}$ até que ocorresse a fratura. Para o teste de microinfiltração marginal foram utilizados 46 molares humanos extraídos, os quais foram divididos em dois grupos, de acordo com cada material. Foram realizados preparos classe $V$, com margem oclusal em esmalte e margem cervical em cemento. Após a realização das restaurações, os dentes foram armazenados em água destilada a $37^{\circ} \mathrm{C}$ por 24 horas, termociclados por 800 ciclos em banhos de 30 segundos nas temperaturas de $6^{\circ} \mathrm{C}$ e $60^{\circ} \mathrm{C}$ e 
novamente armazenados em solução de azul de metileno a 5\% por 4 horas. Os dentes foram seccionados e a microinfiltração marginal foi avaliada por dois examinadores através de um microscópio binocular com 10 vezes de aumento, seguindo um critério de escores pré-estabelecidos, tanto na parede oclusal como na gengival. Os resultados do teste de resistência adesiva para as duas ligas de amálgama foram praticamente os mesmos, com valores de 3,38 MPa para o Valiant e de 3,84MPa para o Dispersalloy, bem inferiores que os obtidos com a resina composta, sendo que não houve diferença estatisticamente significante entre o grupo sem ou com termociclagem (22,38 MPa e 20,86 Mpa, respectivamente). Quanto à microinfiltração marginal, os autores concluíram que 0 adesivo Amalgambond 4-Meta apresentou valores significantemente menores que o verniz cavitário tanto nas margens em esmalte como naquelas em cemento.

Em 1991, CHARLTON; MURCHISON; MOORE ${ }^{30}$ estudaram a influência de dois adesivos resinosos (Panavia EX e Amalgambond 4-Meta) na resistência à compressão e "creep" de uma liga com alto teor de cobre (Tytin). Para a realização dos testes, foram preparados cilindros com auxílio de um molde de teflon, divididos em três grupos: grupo 1 - somente amálgama; grupo 2 - uma camada de adesivo Panavia EX nas paredes do molde + amálgama, seguido da apicação de Oxyguard; grupo 3 - adesivo Amalgambond, seguido da aplicação da mistura entre base e catalisador do material + amálgama. A condensação foi realizada com auxílio de um peso de 14MPa por 90 segundos ou manualmente, através de 10 condensadas firmes com um instrumento de $3 \mathrm{~mm}$ de diâmetro. A resistência à compressão foi testada após 1 hora, 24 horas e 7 dias após o preparo dos espécimes. Já o "creep" foi avaliado após 7 dias. Quando o peso foi utilizado para condensar o amálgama, não houve diferença entre os três grupos quanto à resistência à compressão em todos os períodos testados. Porém, quando a condensação foi manual, houve diferença significante para o grupo 2, já que o adesivo Panavia EX apresentou uma marcante redução da resistência, principalmente após 24 horas e 7 dias. Quanto ao "creep", não houve diferença entre os 3 grupos, tanto na condensação manual quanto na mecânica.

Em 1991, sabendo de sua grande capacidade de vedamento marginal, de união aos tecidos dentários, da possibilidade de se unir a metais não nobres, de seu baixo coeficiente de difusão térmica e da sua propriedade de liberação de flúor, ABOUSH; ELDERTON ${ }^{1}$ estudaram in vitro a força de união do amálgama 
Dispersalloy ao CIV Vitrabond e ao adesivo Scotchbond. As restaurações foram realizadas em blocos de resina acrílica, nas quais havia perfurações de $5 \mathrm{~mm}$ de diâmetro e $2 \mathrm{~mm}$ de profundidade. Foram aplicadas duas camadas de Vitrabond, sendo cada uma fotopolimerizada por 30 segundos. Sobre esta superfície foi aplicada um dos seguintes materiais: grupo 1 - adesivo Scotchbond, fotopolimerizado por 10 segundos; grupo 2 - uma fina camada de Vitrabond sem polimerizar; grupo 3 - líquido do Vitrabond aplicado por 60 segundos. No total, foram realizados 120 corpos de prova. Após a aplicação do material intermediário, o amálgama foi condensado imediatamente. A metade dos espécimes foi estocada em água a $37^{\circ} \mathrm{C}$ por 24 horas, no escuro, enquanto a outra metade foi estocada a $37^{\circ} \mathrm{C}$ em umidade relativa de $95 \%$, também no escuro. Após este período, os espécimes foram levados a uma máquina universal Instron para realização do teste de tração. Os melhores resultados foram obtidos com o grupo 2 em meio úmido $(5,1 \mathrm{MPa})$ e em água ( $3 \mathrm{MPa}$ ), enquanto os valores adesivos mais baixos foram encontrados quando o líquido do Vitrabond foi utilizado em meio úmido $(0,48 \mathrm{MPa})$ e em água $(0,59 \mathrm{MPa})$. Após a análise dos resultados, os autores concluíram que a utilização de uma camada de Vitrabond sem polimerizar fornece grande superioridade nos resultados de resistência à tração quando comparado aos outros materiais intermediários testados, salientando que o Vitrabond é capaz de se polimerizar mesmo sem a exposição à luz polimerizadora.

ARCORIA; FISHER; WAGNER ${ }^{8}$, em 1991, determinaram o efeito de uma base de CIV na microinfiltração marginal em restaurações de amálgama. Ao pó do CIV (Fuji II) foi adicionado pó de liga de amálgama, numa proporção de 1:7 em volume. Foram utilizados 48 molares humanos extraídos, nos quais foram preparadas cavidades classe $V$ na face vestibular de $2,5 \mathrm{~mm}$ de diâmetro e $2,5 \mathrm{~mm}$ de profundidade, com margens localizadas em esmalte. Em 24 dentes, a dentina exposta foi coberta por uma camada de $1 \mathrm{~mm}$ de CIV, enquanto nos outros 24 este material não foi aplicado. Após a aplicação do CIV, metade das amostras forradas e não forradas foi coberta pelo verniz do CIV. Todos os dentes foram restaurados com a liga Tytin e metade do total da amostra foi termociclada em água deionizada nas temperaturas de $5^{\circ} \mathrm{C}$ e $55^{\circ} \mathrm{C}$ por 5 dias, com banhos de 30 segundos e tempo entre os banhos de 10 segundos. Os dentes foram imersos em solução de azul de metileno a $0,5 \%$ por 24 horas, seccionados e avaliados em microscópio com 100X de aumento, seguindo um critério de escores. A utilização de uma base de CIV e de 
seu verniz diminuiu a microinfiltração nas restaurações quando comparado aos grupos sem estes materiais, sendo que a presença do CIV foi o fator que mais diminuiu a microinfiltração marginal. A termociclagem não interferiu na penetração do corante, exceto nos grupos com CIV + verniz termociclados e CIV + verniz não termociclados.

Em 1992, CHARLTON; MOORE; SWARTZ ${ }^{29}$ avaliaram a microinfiltração marginal e a retenção de restaurações de amálgama (Tytin), comparando diferentes materiais intermediários. Para o teste de microinfiltração marginal foram utilizados 100 caninos e pré-molares, nos quais foram preparadas cavidades classe V abrangendo esmalte e cemento. Os dentes foram divididos em 5 grupos: grupo 1 apenas amálgama; grupo 2 - verniz Copalite; grupo 3 - adesivo Prisma Universal Bond 2; grupo 4 - adesivo Panavia EX; grupo 5 - adesivo Amalgambond 4-Meta. As amostras foram armazenadas em água destilada a $37^{\circ} \mathrm{C}$ por 24 horas e termocicladas por 2500 ciclos nas temperaturas de $5^{\circ} \mathrm{C}$ e $45^{\circ} \mathrm{C}$, sendo posteriormente estocadas por mais 5 dias em água destilada a $37^{\circ} \mathrm{C}$. Em seguida foram armazenadas em uma solução aquosa de um corante fluorescente a $2 \%$ (Zylo Penetrant Zh-54) por 24 horas, numa temperatura de $37^{\circ} \mathrm{C}$. Após este período, os espécimes foram avaliados em um estereromicroscópio com aumento de 25 vezes, utilizando lâmpadas ultravioletas para classificar a microinfiltração marginal em escores. Para o teste de retenção foram utilizados 100 molares, os quais tiveram a coroa separada da raiz na junção amelocementária. As coroas foram montadas em um dispositivo de acrílico e nelas foi preparada uma cavidade, que foi lavada com água oxigenada a $3 \%$ por 10 segundos. Os espécimes foram divididos em 5 grupos: grupo 1 - sem qualquer material intermediário; grupo 2 - verniz Copalite; grupo 3 Prisma Universal Bond 2; grupo 4 - Panavia Ex; grupo 5 - Amalgambond. Após a restauração, os dentes foram armazenados em água destilada a $37^{\circ} \mathrm{C}$ durante 24 horas, termociclados por 2500 ciclos nas temperaturas de $5^{\circ} \mathrm{C}$ e $45^{\circ} \mathrm{C}$ e novamente armazenados em água destilada a $37^{\circ} \mathrm{C}$. Após 5 dias, o teste foi realizado em uma máquina universal Instron. O adesivo Amalgambond 4-Meta apresentou os menores resultados de microinfiltração marginal quando comparado aos outros grupos, que não diferiram entre si, tanto em esmalte como em dentina. Já quanto à adesão, o Amalgambond e o Panavia EX exibiram significantemente maior retenção que os demais grupos, ambos com $37 \mathrm{Kg}$, seguidos pelo Prisma Universal Bond $2(31 \mathrm{Kg})$, sem base intermediária $(26 \mathrm{Kg})$ e Copalite $(22 \mathrm{Kg})$. 
Devido ao grande número de testes disponíveis para medir a microinfiltração marginal em restaurações, CHARLTON; MOORE ${ }^{28}$, em 1992, realizaram um estudo comparando duas técnicas diferentes em restaurações de amálgama forradas com três diferentes materiais restauradores. Foram utilizados 18 caninos e pré-molares humanos hígidos que receberam cavidades classe $V$ na face vestibular, todas com margens em esmalte, sendo posteriormente divididos aleatoriamente em três grupos: grupo 1 - sem tratamento; grupo 2 - duas camadas de verniz Copalite; grupo 3 - aplicação de Amalgambond. O verniz Copalite foi aplicado através de pontas de algodão, com uma secagem com jato de ar após a aplicação da primeira camada, sendo que a segunda foi deixada secar espontaneamente. O Amalgambond foi aplicado de acordo com as instruções do fabricante. Todas as cavidades foram restauradas com a liga Tytin, esculpidas e armazenadas em água deionizada a $37^{\circ} \mathrm{C}$ por uma semana. Posteriormente, os espécimes foram termociclados por 2500 ciclos nas temperaturas de $5^{\circ} \mathrm{C}$ e $45^{\circ} \mathrm{C}$, com banhos de 30 segundos intercalados por um tempo de transferência de 10 segundos, sendo posteriormente imersos em água deionizada a $37^{\circ} \mathrm{C}$. Após 6 meses, os dentes foram imersos por 2 horas em solução aquosa de $\mathrm{Ca}_{45}$ e lavados em água corrente por 1 hora. Em seguida, os espécimes foram imersos em solução de corante fluorescente a $2 \%$ por 24 horas a $37^{\circ} \mathrm{C}$ e seccionados no sentido vestíbulo-lingual para a realização das avaliações através das radiografias ou pela fluorescência, seguindo uma escala de escores pré-estabelecidos. Houve uma diferença estatisticamente significante entre as duas técnicas, sendo que o teste com radioisótopo indicou um grau de microinfiltração marginal maior do que o observado com o corante. Porém, os autores salientam que isto não significa que o teste com o raidioisótopo tenha maior capacidade de discernimento que o outro teste. Houve menor microinfiltração com a utilização do Amalgambond, sendo a diferença estatisticamente significante em relação aos outros grupos, que não diferiram entre si.

Em 1993, AL-MOAYAD; ABOUSH; ELDERTON ${ }^{3}$ avaliaram, in vitro, a efetividade de um CIV (Vitrebond) e de dois adesivos (Amalgambond e Panavia Ex) em unir o amálgama ao esmalte e à dentina, comparando-os ao uso do verniz cavitário e a um grupo sem material intermediário (controles). Foram utilizados 78 molares humanos que receberam cavidades classe $V$ não retentivas na face vestibular, sendo que, destes, 22 foram utilizados para cada grupo experimental e 6 
para cada grupo controle. O Vitrebond foi aplicado através de um pequeno pincel em todas as paredes cavitárias, formando uma fina camada não polimerizada sobre a qual o amálgama foi condensado, seguido de uma fotopolimerização por 30 segundos. Já os outros materiais foram aplicados de acordo com as instruções do fabricante. Durante a condensação, a ponta ativa de uma broca esférica foi mantida no interior da restauração para que ela fosse tracionada no teste de retenção. Após a realização das restaurações, os dentes foram armazenados em água destilada a $37^{\circ} \mathrm{C}$ por 24 horas e testados em uma máquina Instron, com uma velocidade de $2 \mathrm{~mm} /$ minuto. As superfícies fraturadas de cada espécime foram examinadas em um estereomicroscópio para avaliar o tipo de fratura e 2 espécimes de cada grupo foram preparados para exame em microscopia eletrônica de varredura. A utilização de materiais adesivos intermediários melhorou a retenção das restaurações quando comparados aos grupos do verniz ou sem material intermediário. Dentre os grupos experimentais, o Vitrebond apresentou os maiores valores (133N), seguido pelo Amalgambond (109N) e pelo Panavia Ex (82N), sendo a diferença entre o primeiro e o terceiro estatisticamente significante. A análise, realizada no estereomicroscópio, demonstrou que no grupo sem material intermediário houve falha na interface amálgama/dente, enquanto no grupo do verniz houve falha na interface verniz/dente. Com o Vitrebond, 90\% apresentou defeitos grosseiros do esmalte, havendo também fraturas coesivas do CIV e alguns espécimes. Com o Amalgambond não foram verificadas fraturas grosseiras do esmalte, sendo que todo o adesivo permanecia aderido às paredes cavitárias e não ao amálgama, demonstrando que houve falha na interface adesivo - amálgama. Com o Panavia Ex, 50\% dos espécimes apresentou fraturas grosseiras do esmalte e grande parte do adesivo permanecia aderido ao amálgama. Os autores concluíram que o Vitrebond tem um grande potencial para ser aplicado efetivamente em restaurações de amálgama adesivo in vivo.

Em 1993, DUTTON et al. $^{38}$ compararam, in vitro, a microinfiltração marginal de restaurações classe $\mathrm{V}$ de amálgama (Valiant PhD) associados a um adesivo dentinário (Universal Bond 3 - UB3) e a um verniz cavitário (Copalite), com ou sem o resselamento das margens da restauração. Este resselamento consistia no condicionamento do amálgama e da estrutura dentária por 15 segundos com ácido fosfórico a 37\%, lavagem pelo mesmo tempo e secagem, aplicação de resina fluida (UB3) e polimerização por 20 segundos. Foram utilizados 80 molares humanos 
inferiores extraídos, que receberam cavidades classe $V$ na face vestibular, com margens em esmalte e cemento. Eles foram divididos em 8 grupos de 10 dentes cada: grupo 1 - somente amálgama; grupo 2 - duas camadas de Copalite e amálgama; grupo 3 - condicionamento ácido do esmalte com ácido fosfórico a 37\% por 15 segundos, aplicação do UB3 primer e adesivo e amálgama; grupo 4 - UB3 primer somente e amálgama; grupo 5 - idem ao grupo 1 e resselamento; grupo 6 idem ao grupo 2 e resselamento; grupo 7 - idem ao grupo 3 e resselamento; grupo 8 - idem ao grupo 4 e resselamento. Após a realização das restaurações, os dentes foram armazenadas em água destilada por 24 horas em temperatura ambiente, termociclados por 500 ciclos nas temperaturas de $6^{\circ} \mathrm{C}$ e $60^{\circ} \mathrm{C}$, com banhos de 30 segundos e imersos em água destilada por mais 24 horas em temperatura ambiente. Posteriormente, os dentes foram imersos em solução de azul de metileno a $2 \%$ por 4 horas, lavados e seccionados no sentido vestibulolingual para que as fatias pudessem se analisadas em um estereomicroscópio com aumento de 30 vezes, sendo classificadas de acordo com escores pré-estabelecidos. O resselamento das margens da restauração reduziu de maneira estatisticamente significante a taxa de microinfiltração marginal no esmalte de todos os grupos, exceto no grupo 2. Já em dentina, somente o grupo 8 foi significantemente melhor que os outros.

A utilização de adesivos dentinários como agentes de vedamento marginal em restaurações classe II de amálgama ou de resina composta foi objeto de estudo de ARAÚJO; MELLO; HUHTALA ${ }^{7}$, em 1993. Foram testados os adesivos dentinários Scotchbond 2; ARMD; Prisma Bond 3 e XR Bond, os quais foram aplicados sob restaurações de amálgama (Dispersalloy) e das resinas compostas P50, Adaptic II P, APH e XR Bond, em restaurações combinadas de resina e amálgama. Como controle das restaurações de amálgama foi utilizado o verniz cavitário Copalite. Para o estudo, foram utilizados 65 pré-molares humanos extraídos, nos quais foram confeccionadas cavidades classe II com margens em esmalte, $2 \mathrm{~mm}$ aquém da junção esmalte-cemento. Os dentes foram divididos em 13 grupos, sendo 9 restaurados com apenas um dos materiais e 4 com uma associação entre amálgama e resina composta. Nestes grupos, o amálgama foi condensado até o nível da parede pulpar, seguido da aplicação do agente adesivo e da resina composta até a conclusão da restauração. Em seguida, os dentes foram termociclados em corante rodamina B a $2 \%$ por 5 ciclos consecutivos nas temperaturas de $5^{\circ} \mathrm{C}, 37^{\circ} \mathrm{C}$ e $55^{\circ} \mathrm{C}$, com banhos de 3 minutos e posteriormente 
foram mantidos no mesmo corante em temperatura ambiente por 24 horas. Os dentes foram seccionados no sentido mésio-distal e as fatias foram avaliadas com lupa estereomicroscópia, segundo um critério de escores pré-estabelecidos. A utilização de adesivos dentinários diminuiu a microinfiltração marginal das restaurações classe II de amálgama, resina composta ou amálgama + resina composta. Os piores resultados foram obtidos com o uso do verniz cavitário, com valores de microinfiltração marginal estatisticamente significantes aos demais. Os testes demonstraram que a microinfiltração marginal das restaurações de resina composta associadas a adesivos dentinários não é estatisticamente diferente daquela obtida com restaurações de amálgama associadas aos adesivos.

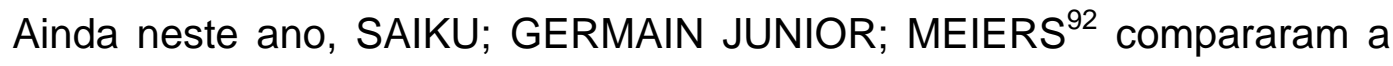
microinfiltração marginal ocorrida em restaurações de amálgama (Tytin e Dispersalloy) realizadas com o adesivo Amalgambond, com um verniz copal (Copalite) ou sem qualquer material intermediário. Foram utilizados 40 molares, nos quais foram realizadas cavidades classe $\mathrm{V}$ nas superfícies mesial e distal, com margens localizadas $0,5 \mathrm{~mm}$ além da junção cemento-esmalte. Após a realização das restaurações, os dentes foram armazenados em água por 24 horas a $37^{\circ} \mathrm{C}$, com exceção de dois grupos que foram deixados por 30 dias. Após a armazenagem, foram termociclados em solução de fucsina básica a $0,5 \%$ em temperaturas de $5^{\circ} \mathrm{C}$ e $55^{\circ} \mathrm{C}$, com banhos de 30 segundos, totalizando 3000 ciclos. Os dentes foram então seccionados longitudinalmente e tratados com ácido cítrico a 0,5\% por 5 segundos para remoção da "smear layer" e analisados por dois examinadores com um estereromicroscópio com um aumento de 10 vezes, de acordo com escores préestabelecidos. A utilização do Amalgambond diminuiu significantemente a microinfiltração marginal, quando comparado aos outros grupos. A microinfiltração marginal em dentina e em esmalte foi reduzida significantemente com o uso do adesivo sob as restaurações de amálgama, tanto com a liga Dispersalloy como Tytin. A associação entre Amalgambond e Dispersalloy apresentou uma microinfiltração marginal menor estatiscamente que o conjunto Amalgambond e Tytin, nas margens em esmalte. A penetração do corante aumentou de forma estatisticamente significante em todos os grupos quando a termociclagem foi realizada 30 dias após a restauração, o que pode ter ocorrido devido a uma degradação hidrolítica dos agentes intermediários. O padrão de microinfiltração marginal com a utilização do adesivo sob as restaurações de amálgama se restringiu 
à interface entre estes dois materiais, havendo pequena penetração no interior dos túbulos dentinários. Já nos grupos sem material intermediário e Copalite, observouse penetração do corante nos túbulos dentinários, inclusive atingindo a câmara pulpar em alguns casos. Não houve diferença entre os grupos do verniz Copalite e sem material intermediário.

Em 1994, BAGLEY; WAKEFIELD; ROBBINS ${ }^{9}$ compararam, in vitro, a capacidade de 4 sistemas adesivos em unir o amálgama à estrutura dentária. Foram utilizados 90 dentes humanos extraídos que tiveram suas superfícies mesial e distal preparadas até a formação de uma superfície plana, em dentina. Eles foram divididos em 4 grupos: grupo 1 - Amalgambond Plus de acordo com as instruções do fabricante; grupo 2 - Amalgambond Plus associado ao pó de HPA (aditivo de alta performance), composto por fibras de metil metacrilato; grupo 3 - All Bond 2; grupo 4 - All Bond 2 associado ao Liner F. Após a aplicação do agente adesivo, o amálgama (Tytin) foi condensado manualmente e os dentes foram estocados em água deionizada por 96 horas. Posteriormente, sofreram um teste de cizalhamento em uma máquina Instron, com uma velocidade de $5 \mathrm{~mm} /$ minuto. Os melhores resultados foram encontrados com o All Bond 2 associado ao Liner $F(11,73 \mathrm{MPa})$, seguido pelo Amalgambond Plus associado ao HPA $(9,20 \mathrm{MPa})$, All Bond 2 (5,84MPa) e Amalgambond Plus $(2,26 \mathrm{MPa})$. Os autores concluíram que a adição de componentes com carga nos sistemas resinosos aumenta a força de adesão entre o dente e o amálgama, quando comparados com os mesmos sistemas sem estes aditivos.

Com o objetivo de avaliar a microinfiltração marginal em restaurações de amálgama (Permite $\mathrm{C}$ ) realizadas com diferentes sistemas adesivos, BERRY; $\mathrm{TJAN}^{21}$, em 1994, utilizaram 40 molares humanos extraídos, nos quais foram confeccionadas cavidades classe I com $1,5 \mathrm{~mm}$ de largura e $0,5 \mathrm{~mm}$ de profundidade atingindo a dentina. Eles foram divididos em 4 grupos de 10 dentes cada: grupo 1 duas camadas de verniz Copalite intercaladas por jato de ar e amálgama; grupo 2 Scotchbond 2 (primer e adesivo), fotopolimerização e amálgama; grupo 3 - Prisma Universal Bond (primer e adesivo), fotopolimerização e amálgama; Pertac Universal Bond, fotopolimerização e amálgama. Em todos os grupos não foi realizado 0 condicionamento ácido da cavidade, já que, segundo os autores, o objetivo do trabalho era de avaliar a capacidade de vedamento marginal dos materiais e não a resistência adesiva. Após a condensação do amálgama, a restauração foi esculpida 
e os espécimes foram mantidos em água a $37^{\circ} \mathrm{C}$ por 90 dias. Após este período, foram termociclados por 300 ciclos com temperaturas de $5^{\circ} \mathrm{C}$ e $55^{\circ} \mathrm{C}$ em solução de fucsina básica a 0,5\%, permanecendo um minuto em cada banho. Posteriormente foram seccionados no sentido mesio-distal e vestíbulo-lingual para avaliação da microinfiltração marginal com um aumento de 100 vezes, classificando-a de acordo com escores. Todos os adesivos promoveram melhor vedamento marginal que o grupo que recebeu o verniz Copalite, com resultados estatisticamente significantes. Numa comparação entre os adesivos, observou-se que o Prisma Universal Bond 3 e o Pertac Universal Bond originaram melhores resultados quando comparados ao Scotchbond 2, sendo esta diferença estatisticamente significante.

Em 1994, BEARN; SAUNDERS; SAUNDERS ${ }^{11}$ realizaram uma revisão de literatura sobre os aspectos clínicos e teóricos a respeito do assunto e apresentaram quatro casos clínicos nos quais foi obtido sucesso no tratamento de dentes trincados. Para o tratamento dos dentes com trincas recomenda-se o ajuste oclusal, restauração de resina composta, restauração de amálgama com sulcos ou pinos, cimentação de bandas, confecção de coroas com cobertura de cúspide e até mesmo coroas completas. Além destas, a técnica do amálgama adesivo também poderia ser utilizada, sendo possível prevenir uma flexão da cúspide afetada para aliviar a dor e prevenir a propagação da trinca. Neste artigo, os autores relatam casos nos quais foram realizadas associações entre o amálgama e o Panavia Ex, com controle de até 18 meses. Como vantagens desta técnica, os autores salientam as seguintes: preservação de estrutura dentária sadia, já que há menor necessidade de retenções adicionais; menor sensibilidade técnica, ausência do problema de contração de polimerização e melhores propriedades mecânicas quando comparada às restaurações com resina composta; menor microinfiltração marginal que as restaurações convencionais realizadas com verniz cavitário; redução da flexão cuspídea.

Ainda neste ano, BEN-AMAR et al. ${ }^{20}$ realizaram um estudo com o intuito de avaliar a capacidade de vedamento marginal do Amalgambond e do verniz cavitário sob restaurações de amálgama (Tytin), comparando-os com um grupo sem qualquer material forrador. Foram utilizados 105 molares e pré-molares humanos extraídos, nos quais foram preparadas cavidades classe $V$ na junção amelocementária com $1,8 \mathrm{~mm}$ de profundidade nas faces vestibular e lingual. Os dentes foram divididos em três grupos: grupo 1 - sem forramento (controle); grupo 2 
- verniz Copalite; grupo 3 - Amalgambond. Todos os materiais foram aplicados de acordo com as instruções do fabricante. Cada grupo foi dividido em subgrupos de acordo com o tempo de armazenagem, que foi de 14 dias, 6 meses ou 1 ano. Os dentes foram armazenados em água a $37^{\circ} \mathrm{C}$ durante os períodos mencionados, sendo que posteriormente sofreram cargas oclusais de $10 \mathrm{Kg}$ por 0,5 segundos, num total de 500 ciclos em uma máquina de ensaios AMI II. Em seguida, os dentes foram termociclados por 100 vezes nas temperaturas de $5^{\circ} \mathrm{C}$ e $55^{\circ} \mathrm{C}$, com banhos de 10 segundos e um tempo de 10 segundos entre cada imersão. Em seguida foram imersos por 48 horas em solução de fucsina básica a $0,5 \%$ a $37^{\circ} \mathrm{C}$, seccionados no sentido vestíbulo-lingual no centro da restauração e avaliados quanto à distância de penetração do corante nas paredes oclusal e gengival, seguindo uma ordem de escores, e quanto à penetração ou não de corante nos túbulos dentinários, ambos vistos em microscópio de luz refletida com aumento de 1 a 50 vezes. 0 Amalgambond forneceu menor penetração de corante nos túbulos dentinários quando comparado aos outros grupos em todos os períodos testados. Quanto à microinfiltração marginal, menores valores foram observados com 0 uso do Amalgambond quando comparado ao grupo 1 (todos os períodos) e grupo 2 (14 dias). A microinfiltração observada no grupo controle foi similar em todos os perídos testados.

Em 1994, GWINNETT et al. ${ }^{45}$ realizaram uma revisão de literatura sobre as restaurações adesivas com amálgama, salientando as indicações, vantagens, desvantagens e técnica operatória. Como vantagens do amálgama como material restaurador, eles ressaltaram a sua grande aceitação e baixa sensibilidade técnica, performance clínica previsível, custo baixo, autovedamento das margens, menor necessidade de treinamento e habilidade do operador, além do curto tempo clínico devido à fácil manipulação. Como desvantagens do amálgama eles citam a cor, a falta de adesão à estrutura dentária e a necessidade de confecção de uma cavidade com retenções mecânicas, bem como a preocupação referente à toxicidade do mercúrio. As vantagens da técnica do amálgama adesivo são o menor custo que restaurações metálicas fundidas ou metalocerâmicas; possibilidade de restauração de dentes com pequena altura gêngivo-oclusal, diferente do amálgama convencional, com pinos, amalgapin, "inlays", "onlays" e coroas completas; permite a confecção de cavidades mais conservadoras porque não requer a confecção de retenções adicionais; elimina o risco de perfuração da cavidade pulpar ou do espaço 
periodontal durante a confecção de um pin ou de fixação de um pino; redução da microinfiltração marginal; reforço da estrutura dentária enfraquecida pela cárie e pelo preparo cavitário; redução da sensibilidade pós-operatória, incidência de fraturas marginais e de cárie secundária; possibilita a restauração definitiva de um dente com coroa enfraquecida em uma única sessão; promove o selamento do complexo dentinopulpar. Quanto às desvantagens ou limitações, eles salientam o aumento do tempo de trabalho e da sensibilidade da técnica; necessidade de adaptação a uma nova técnica; aumento custo; pode parecer ser viável o uso do amálgama em situações em que ele não está indicado; pouco tempo de avaliação da performance clínica da técnica até aquela época. Na descrição da técnica, afirmam que o preparo cavitário requer uma adequada forma de resistência, como, por exemplo, redução de cúspides ou de paredes cavitárias enfraquecidas para que elas possam ser protegidas pelo amálgama. Em cavidades amplas, mesmo com o adesivo, é necessário que sejam realizadas retenções adicionais na estrutura dentária remanescente. Quanto à técnica de aplicação do adesivo, salientam a necessidade de seguir as recomendações do fabricante.

A preocupação com a quantidade de cimento resinoso aplicado sob 0 amálgama fez com que MILLSTEIN; NAGUIB ${ }^{64}$, em 1995, realizassem um estudo in vitro com o intuito de avaliar a influência deste fator na resistência à tensão diametral e à compressão das restaurações feitas com Dispersalloy. Foram utilizados 5 grupos: grupo 1 - uma porção de Amalgambond; grupo 2 - 3 porções de Amalgambond; grupo 3 - uma porção de Panavia; grupo 4 - 3 porções de Panavia; grupo 5 - somente amálgama. Os espécimes foram obtidos através de um molde de teflon cilíndrico de $3 \mathrm{~mm}$ de altura e $4 \mathrm{~mm}$ de diâmetro, dentro do qual o material intermediário foi aplicado antes da condensação do amálgama. Foram obtidos 200 cilindros de amálgama, sendo 20 para cada grupo. Após a realização das restaurações, os dentes foram termociclados nas temperaturas de $5^{\circ} \mathrm{C}$ e $55^{\circ} \mathrm{C}$, com banhos de 15 segundos e espera de 15 segundos entre um banho e outro antes de serem testados em uma máquina de ensaios Instron, com uma velocidade de $0,5 \mathrm{~mm} /$ segundo. No teste de compressão não foram observadas diferenças entre todos os grupos. Já no teste de tração, observou-se que o Panavia apresentou os piores resultados (grupo 3: $46 \mathrm{Kg}$ e grupo 4: $38 \mathrm{Kg}$ ), enquanto os melhores resultados foram obtidos com os grupos $1(64 \mathrm{Kg})$ e $5(61 \mathrm{Kg})$. Os autores concluíram que as 
resinas adesivas não enfraquecem as restaurações de amálgama, porém devem ser usadas com cuidado, evitando a aplicação do material em excesso.

Ainda neste ano, TURNER; GERMAIN JUNIOR; MEIERS ${ }^{104}$ avaliaram in vitro a microinfiltração marginal ocorrida com vários adesivos dentinários utilizados sob restaurações de amálgama, realizadas com duas ligas diferentes (Tytin e Dispersalloy). Foram utilizados 60 molares humanos, nos quais foram preparadas cavidades classe $\mathrm{V}$ nas faces mesial e distal, com $1,5 \mathrm{~mm}$ de profundidade e parede gengival $0,5 \mathrm{~mm}$ além da junção cemento-esmalte. As 120 cavidades foram divididas em 12 grupos, sendo 6 para cada tipo de liga, variando o material intermediário aplicado: nenhum, Copalite, Amalgambond Plus, Tenure / Panavia, Syntac / Dual Cem e All Bond 2 / Liner F. Os materiais foram aplicados de acordo com as instruções do fabricante e o amálgama foi condensado manualmente, brunido e esculpido. Todos os dentes foram armazenados em água deionizada por 24 horas à temperatura ambiente, termociclados por 3000 ciclos entre $5^{\circ} \mathrm{C}$ e $55^{\circ} \mathrm{C}$ em banhos de 30 segundos em fucsina básica a $0,5 \%$ e seccionados no sentido mesiodistal. As fatias foram avaliadas por dois examinadores em um microscópio com aumento de 10 vezes, classificando a microinfiltração marginal em escores. Foram também realizadas impressões de secções representativas de cada grupo e obtenção de modelos em resina epóxica para que eles pudessem ser avaliados em MEV, com a finalidade de analisar a interface dente / adesivo / amálgama. Todas as restaurações adesivas apresentaram menor penetração do corante quando comparadas ao verniz cavitário ou quando não foi utilizado nenhum material intermediário, independente do tipo de liga. Comparando os diferentes materiais adesivos, os melhores resultados foram obtidos com o Tenure / Panavia Ex para a liga Tytin e com o Syntac / Dual Cem para a liga Dispersalloy. Com a utilização dos adesivos pôde-se notar que o corante penetrou na interface amálgama / resina adesiva com pouca ou nenhuma penetração nos túbulos dentinários. Já nos grupos do verniz cavitário ou sem material intermediário observou-se que o corante penetrou na interface amálgama / dentina com penetração nos túbulos dentinários. Em uma avaliação individual dentro de cada grupo, observou-se que a parede gengival permitia maior microinfiltração marginal que a oclusal. A análise em MEV mostrou que no grupo com verniz cavitário e no grupo sem material intermediário houve a formação de fendas marginais, com os túbulos dentinários abertos. Já nos grupos dos materiais 
adesivos, foi observada a presença de uma linha resinosa junto à dentina, o que prevenia a penetração do corante em seus túbulos.

Também em um estudo in vitro, $\mathrm{CHAIN}^{27}$, em 1995, avaliou a microinfiltração marginal em restaurações de amálgama (Dispersalloy) associadas ao adesivo Amalgambond ou ao verniz cavitário Cavi-line. Foram realizados preparos cavitários classe $\mathrm{V}$ na face vestibular de 40 molares, com a parede cervical em cemento e a parede oclusal em esmalte. Os dentes foram igualmente divididos em dois grupos, de acordo com o material forrador aplicado. Após a realização das restaurações, todos os espécimes foram armazenados em água destilada por 24 horas a $37^{\circ} \mathrm{C}$, termociclados por 24 horas (800 ciclos) nas temperaturas de $6^{\circ} \mathrm{C}$ e $60^{\circ} \mathrm{C}$, com um intervalo entre os banhos de 30 segundos e imersos em solução de azul de metileno a $2 \%$ por 24 horas. Após este período, os dentes foram lavados em água corrente por 24 horas e seccionados através do centro da restauração para avaliação em um microscópio estereobinocular com um aumento de 10 vezes por dois examinadores. As paredes oclusal e gengival foram analisadas separadamente, seguindo uma ordem de escores. O Amalgambond permitiu menor microinfiltração marginal que o Cavi-line em ambas as paredes, sendo os valores maiores na cervical.

Com o objetivo de avaliar a microinfiltração marginal em restaurações de amálgama classe II, DUARTE JUNIOR ${ }^{37}$, em 1995, verificou o efeito de vernizes cavitários, vernizes terapêuticos e adesivos dentinários. Foram realizados preparos classe $\mathrm{V}$ nas faces vestibular e lingual de 30 molares com a parede cervical localizada $1 \mathrm{~mm}$ além da junção esmalte / cemento, totalizando 50 cavidades. Todas foram restauradas com a liga Tytin, variando apenas no material intermediário utilizado: Universal Cavity Varnish, Fluorniz, Duraphat e Prisma Universal Bond 3. No grupo controle não foi aplicado nenhum material protetor. As restaurações foram polidas após 24 horas e os dentes foram termociclados nas temperaturas de $10^{\circ} \mathrm{C}$ e $50^{\circ} \mathrm{C}$ em solução de azul de metileno a $2 \%$, num total de 100 ciclos, com banhos de 15 segundos. Para a análise da microinfiltração marginal, os dentes foram seccionados no centro da restauração e examinados com uma lupa estereoscópica com aumento de 20 vezes, tanto na parede cervical com na oclusal, seguindo uma escala de escores. Houve maior microinfiltração na parede cervical que na oclusal, sendo que o verniz cavitário não alterou os níveis de penetração do corante quando comparada ao grupo controle, apresentando valores máximos. Os melhores 
resultados foram obtidos com o Prisma Universal Bond 3, com resultados estatisticamente significantes se comparado ao verniz cavitário. Não foi observada diferença estatisticamente significante entre o adesivo e os vernizes terapêuticos (Fluorniz e Duraphat).

Com o objetivo de avaliar a influência do material intermediário e do tempo de armazenagem dos espécimes na microinfiltração marginal em restaurações de amálgama (Dispersalloy), MOORE; WILLIAN; KAPLAN ${ }^{66}$, em 1995, realizaram um estudo in vitro utilizando o adesivo Amalgambond e o verniz cavitário Copalite. Foram realizadas cavidades classe V com margens em esmalte em 180 dentes humanos, os quais foram divididos em dois grupos de acordo com o material intermediário e em três subgrupos de acordo com o tempo de armazenagem em solução salina normal a $37^{\circ} \mathrm{C}$ : uma semana, seis meses e um ano. Após a realização das restaurações de acordo com as instruções do fabricante, os dentes foram termociclados nas temperaturas de $4^{\circ} \mathrm{C}$ e $58^{\circ} \mathrm{C}$, com um minuto em cada banho, totalizando 100 ciclos, sendo posteriormente mergulhados em solução de azul de metileno a $5 \%$ por 4 horas. Os dentes foram seccionados através do centro da restauração e a avaliação foi procedida em um microscópio binocular com um aumento de 20 vezes, classificando-se a penetração do corante em escores. Após uma semana e seis meses, as amostras apresentaram uma microinfiltração marginal significantemente menor no grupo com Amalgambond $(0,49$ e 0,34, respectivamente) quando comparadas com o grupo do Copalite (1,36 e 2,53, respectivamente). Após um ano, observou-se um aumento da microinfiltração no grupo com Amalgambond $(0,93)$, enquanto a mesma diminuiu no grupo com verniz $(0,97)$, ficando os dois grupos com resultados semelhantes. No grupo do Copalite, o aumento da microinfiltração marginal após 6 meses pode ter ocorrido pela dissolução do verniz e sua diminuição após um ano pode ter ocorrido pela formação e deposição dos produtos de corrosão. Já o aumento da microinfiltração após um ano no grupo do Amalgambond pode ser devido à ruptura das ligações adesivas com a estrutura dentária.

Em 1996, KORALE; MEIERS ${ }^{53}$ avaliaram a efetividade de sistemas adesivos dentinários na prevenção da microinfiltração marginal em restaurações de amálgama. Foram utilizados 60 molares humanos extraídos, nos quais foram preparadas cavidades classe $\mathrm{V}$ nas superfícies mesial e distal, com margens oclusal em esmalte e gengival em cemento. Os dentes foram divididos em 12 grupos: sem 
base forradora, verniz Copalite e os adesivos Tenure, Syntac, Amalgambond e AllBond 2, sendo que foram utilizadas duas ligas diferentes de amálgama (Tytin e Dispersalloy). Após a realização das restaurações, os dentes foram armazenados em água deionizada por 24 horas, termociclados por 3000 ciclos em água nas temperaturas de $5^{\circ} \mathrm{C}$ e $55^{\circ} \mathrm{C}$, com banhos de 30 segundos e imersos em solução de fucsina básica a $0,5 \%$ a $37^{\circ} \mathrm{C}$ por 24 horas. Os dentes foram seccionados e as fatias foram avaliadas em um microscópio com aumento de 10 vezes por dois examinadores, classificando a penetração do corante de acordo com escores. Para ambas as ligas, os adesivos dentinários demonstraram uma microinfiltração marginal significantemente menor, com uma menor porcentagem de penetração de corante nos túbulos dentinários, tanto na parede cervical como na oclusal, quando comparados ao grupo do Copalite ou sem base forradora, que apresentaram aproximadamente $95 \%$ dos espécimes com penetração do corante nos túbulos dentinários na parede cervical. Dentre os adesivos, o Syntac permitiu maior penetração do corante na parede oclusal e, na cervical, os piores resultados foram obtidos com o Syntac e o Tenure. Houve maior penetração de corante na parede cervical, sendo os resultados estatisticamente significantes. Não houve diferença estatisticamente significante entre as duas ligas utilizadas.

Em 1996, BERRY et al. ${ }^{22}$, analisaram in vitro a microinfiltração marginal em restaurações de amálgama, usando apenas os primers de vários sistemas adesivos ou o verniz cavitário como material intermediário, além de avaliar a influência do ataque ácido. Foram preparadas cavidades classe I em 140 molares humanos extraídos, divididos em 14 grupos: grupo 1 - sem base intermediária; grupo 2 - duas camadas de Copalite; grupo 3a - Amalgambond aplicado em esmalte e dentina; grupo $3 b$ - condicionamento ácido e Amalgambond; grupo 4a aplicação do primer do Scotchbond Multi-Purpose; grupo 4b - condicionamento ácido e aplicação do primer do Scotchbond Multi-Purpose; grupo 5a - aplicação do primer do Pro-Bond; grupo $5 \mathrm{~b}$ - condicionamento ácido e aplicação do primer do Pro-Bond; grupo 6a - aplicação do primer do All-Bond 2; grupo 6b condicionamento ácido e aplicação do primer do All-Bond 2; grupo 7a - primer do Optibond; grupo $7 \mathrm{~b}$ - condicionamento ácido e primer do Optibond; grupo 8a aplicação do primer do Persagem; grupo 8b - condicionamento ácido e aplicação do primer do Persagem. Todos os dentes foram restaurados com a liga Dispersalloy, armazenados por 24 horas a $37^{\circ} \mathrm{C}$, polidos e novamente armazenados em água por 
90 dias. Posteriormente sofreram termociclagem em solução de fucsina básica a $0,5 \%$ nas temperaturas de $5^{\circ} \mathrm{C}$ e $55^{\circ} \mathrm{C}$, com banhos de 30 segundos, num total de 300 ciclos. Os dentes foram cortados longitudinalmente e as fatias foram avaliadas em um microscópio com aumento de 100 vezes, respeitando uma seqüência de escores. O verniz cavitário não foi eficaz na prevenção da microinfiltração marginal, apesar de apresentar resultados melhores que os observados no grupo controle, e a realização de condicionamento ácido prévio à aplicação do primer diminui significantemente a microinfiltração marginal em todos os grupos, exceto com Scotchbond, Pro-Bond e Amalgambond. Os autores concluíram que: as restaurações de amálgama sem base intermediária ou com verniz cavitário são ineficientes em prevenir a microinfiltração marginal; a realização de ataque ácido antes da aplicação do primer é um passo crítico na prevenção da microinfiltração marginal e o primers podem ser usados sem o seu agente de união para redução da microinfiltração marginal em restaurações de amálgama.

Para avaliar o grau e o padrão da microinfiltração marginal em restaurações de amálgama, TANGSGOOLWATANA et al. ${ }^{100}$, em 1996, realizaram um estudo in vitro, utilizando dois métodos diferentes de avaliação. Foram utilizados 160 molares humanos extraídos, nos quais foram preparadas cavidades classe II nas faces mesial e distal, sendo que na primeira o término localizava-se em esmalte (1,0mm aquém da junção amelocementária) e na segunda em dentina $(0,5 \mathrm{~mm}$ além da junção). Cada cavidade tinha $1,5 \mathrm{~mm}$ de largura vestíbulo-lingual e 1,0mm de profundidade na parede cervical, com sulcos de retenção. Os dentes foram igualmente divididos em 4 grupos: verniz Copalite; sistema adesivo resinoso com ataque ácido All-Bond 2 / Resinomer; sistema adesivo resinoso sem ataque ácido Panavia 21; e CIV Amalcoden, sendo o amálgama condensado sobre o material ainda em fase plástica. Metade dos espécimes de cada grupo (20 dentes) foi tratada com Rodamina B para posterior análise da microinfiltração marginal em microscópio confocal. Destes 20 dentes, 10 foram restaurados com Dispersalloy e 10 com Tytin. Os dentes foram termociclados por 2500 ciclos em banhos de 30 segundos nas temperaturas de $8^{\circ} \mathrm{C}$ e $48^{\circ} \mathrm{C}$, com um tempo intermediário de 10 segundos. Após este procedimento, os dentes foram armazenados em solução aquosa do radioisótopo $\mathrm{Ca}_{45} \mathrm{Cl}_{2}$ por 2 horas, sendo posteriormente imersos no corante fluoresceína a $0,5 \%$ por 5 minutos. Após o seccionamento, a microinfiltração marginal foi avaliada de acordo com cada técnica. Para a detecção da fluoresceína, 
foi utilizado um microscópio confocal com aumento de 40 vezes e para a detecção da penetração do radioisótopo foram tomadas auto-radiografias em um tempo de 17 horas, sendo que para ambas as técnicas a microinfiltração marginal foi classificada em escores. Os adesivos minimizaram a microinfiltração marginal, sendo que os melhores resultados obtidos foram com o All-Bond 2 / Resinomer, seguido pelo Panavia 21 e Amalcoden. $O$ grupo controle exibiu o maior grau de microinfiltração marginal. Não foi observada diferença entre as duas ligas de amálgama utilizadas e houve uma alta correlação entre os resultados obtidos com a fluoresceína e o radioisótopo, o que indica que estes dois métodos podem ser diretamente comparados.

Em um estudo in vivo, MAHLER et al. ${ }^{58}$, em 1996, avaliaram a eficácia de restaurações de amálgama realizadas com adesivo na resistência à fratura marginal e sensibilidade pós-operatória. Foram selecionados 26 pacientes que necessitavam de pares de restauração classe I ou II, sendo que em uma delas era utilizado o cimento resinoso Panavia 21 e amálgama (Aristaloy), enquanto na outra apenas o amálgama. No total, foram realizadas 100 restaurações em molares e pré-molares. A sensibilidade pós-operatória foi avaliada entre uma e duas semanas após a realização das restaurações, quando os pacientes retornavam para o polimento, utilizando-se um questionário. Já a resistência à fratura foi avaliada após um ano, através de fotografias oclusais. Através dos questionários verificou-se que $15 \%$ dos dentes restaurados com adesivo apresentaram sensibilidade pós-operatória, enquanto $9 \%$ do outro grupo mostraram-se sensíveis. Quanto à análise das fraturas marginais, não foi observada diferença estatisticamente significante entre os dois grupos avaliados. Durante a condensação do amálgama sobre o Panávia 21, os autores relataram que havia um deslocamento do cimento. Com o intuito de avaliar este fato, cinco dentes foram restaurados in vitro e analisados em MEV. Foi observada uma incorporação do cimento no amálgama e um excesso de material nos ângulos da cavidade. Estes fatores poderiam aumentar a fragilidade da restauração em áreas de altos esforços, tais como istmo, vertentes de cúspides e margens. Quanto à resistência à fratura marginal, os autores salientam que não é possível chegar a resultados conclusivos antes do $2^{\circ}$ ou $3^{\circ}$ anos de avaliação, embora seus resultados tenham demonstrado não haver diferença significante. 
A utilização de bases e vernizes é recomendada para a realização de restaurações de amálgama. Porém, o desenvolvimento de novas bases e materiais, aliado a um maior conhecimento sobre a biologia pulpar, está levantando um questionamento sobre estas indicações. Devido a isso, em 1996, HILTON ${ }^{47}$ realizou uma revisão de literatura a respeito dos materiais de proteção pulpar disponíveis no mercado, descrevendo suas indicações e relações biológicas com o complexo dentinopulpar. Segundo o autor, não existe nenhum material artificial que possa proteger a polpa melhor que a própria dentina. Uma camada deste tecido de $0,5 \mathrm{~mm}$ é capaz de reduzir em $75 \%$ o nível de toxicidade dos materiais aplicados sobre ela, enquanto uma camada de $2 \mathrm{~mm}$ permitirá uma reação pulpar pequena ou ausente. Segundo o autor, estas reações adversas da polpa são decorrentes da invasão bacteriana ou da ação de suas toxinas. Os materiais desenvolvidos para selar cavidades, mais recentes na época, eram os cimentos resinosos, os CIV e os agentes adesivos, sendo que a capacidades dos mesmos de unir as resinas compostas aos tecidos dentários é aceitável e está bem documentada. A sua biocompatibilidade está diretamente relacionada com sua capacidade de união e vedamento marginal. Por isso, a maior dúvida estaria no tempo em que este processo adesivo seria capaz de manter uma barreira contra a penetração bacteriana, considerando todas as reações adversas que ocorrem na cavidade bucal. Quanto às restaurações de amálgama associadas a adesivos, havia muita controvérsia na literatura. Os prováveis benefícios desta associação seriam a diminuição da microinfiltração marginal e da sensibilidade térmica, aumento da retenção e reforço da estrutura dentária remanescente. Uma desvantagem deste procedimento é a insolubilidade dos adesivos, já que assim eles agiriam como uma barreira que impede o vedamento promovido pelos produtos da corrosão, havendo um maior risco de microinfiltração marginal e cárie. Quanto à retenção e ao reforço da estrutura dentária, o autor relata que os resultados das pesquisas não são conclusivos e que apenas alguns estudos in vitro demonstram alguma vantagem. Além disso, ele questiona se os procedimentos adesivos em restaurações de amálgama não alterariam as propriedades físicas do material restaurador pela incorporação de adesivo. A sua conclusão foi de que deve haver cautela no uso desta técnica, apesar dos resultados promissores.

Também em 1996, NEWMAN JUNIOR; HONDRUM; CLEM $^{73}$ avaliaram in vitro a microinfiltração marginal em restaurações de amálgama realizadas com o 
verniz Copalite, o CIV Vitrebond e o adesivo Amalgambond Plus. Foram utilizados 64 molares humanos extraídos, nos quais foram realizadas cavidades classe $\mathrm{V}$ com margens em esmalte e cemento. Os dentes foram divididos em 4 grupos, todos restaurados com a liga Tytin: grupo 1 - controle, sem nenhum material intermediário; grupo 2 - duas camadas de verniz Copalite; grupo 3 - Amalgambond Plus; grupo 4 - Vitrebond fotopolimerizado antes da condensação do amálgama. Depois de realizadas as restaurações, as amostras foram armazenadas em solução fisiológica em temperatura ambiente durante 20 dias, sendo posteriormente mantidos em um ambiente à $37^{\circ} \mathrm{C}$ por 5 dias. Em seguida foi realizada termociclagem de 1000 ciclos nas temperaturas de $5^{\circ} \mathrm{C}$ e $55^{\circ} \mathrm{C}$, com banhos de 30 segundos, armazenagem dos espécimes em fucsina por 24 horas, seccionamento e avaliação das fatias em microscópio com aumento de 10x, sendo a microinfiltração marginal classificada de acordo com escores. Houve maior penetração do corante na parede cervical em todos os grupos testados. O CIV permitiu uma microinfiltração marginal maior que no grupo controle, enquanto o Amalgambond Plus impediu uma adequada condensação do amálgama na cavidade, o que pode ter sido responsável por uma microinfiltração marginal semelhante à observada no grupo controle. Os pobres resultados obtidos com 0 uso do Amalgambond podem ter ocorrido pela armazenagem dos espécimes pelo período de 25 dias, diminuindo a proteção conferida por esta material contra a microinfiltração marginal. Quanto ao CIV modificado por resina, talvez seus valores foram altos devido ao seu coeficiente de expansão térmica maior comparativamente aos CIV convencionais, o que pode causar maior contração e expansão durante a termociclagem. Não houve diferença estatisticamente significante entre os 4 grupos testados, demonstrando que estes materiais não devem ser usados na rotina clínica.

Com o objetivo de avaliar a resistência à fratura de pré-molares restaurados com amálgama associado ao verniz cavitário ou resina adesiva, após diferentes métodos para provocar a fadiga das restaurações, BONILLA; WHITE ${ }^{23}$, em 1996, realizaram um estudo in vitro, salientando a importância de uma união durável entre o amálgama e a estrutura dentária. Foram utilizados 80 pré-molares humanos extraídos e intactos, que receberam preparos cavitários tipo MOD com margens gengivais em cemento. As restaurações de amálgama (Valiant) foram realizadas com verniz cavitário (Copalite) ou resina adesiva (Amalgambond Plus), esculpidas e brunidas. Após 5 minutos, os dentes foram mantidos em um ambiente 
com $100 \%$ de umidade a $37^{\circ} \mathrm{C}$ por 1 hora, sendo então divididos em 4 grupos de acordo com o tipo de fadiga a ser executado: grupo 1 - armazenagem por 24 horas em água a $37^{\circ} \mathrm{C}$; grupo 2 - envelhecimento artificial, que consistiu na armazenagem dos espécimes por 4 semanas em água a $37^{\circ} \mathrm{C}$ e termociclagem nas temperaturas de $5^{\circ} \mathrm{C}$ e $55^{\circ} \mathrm{C}$, com banhos de 30 segundos, num total de 1500 ciclos; grupo 3 armazenagem por 500 dias em água a $37^{\circ} \mathrm{C}$; grupo 4 - armazenagem por 4 semanas em água a $37^{\circ} \mathrm{C}$ e ciclagem mecânica até a ocorrência de fratura. Em todos os grupos o teste de resistência à fratura foi realizado em uma máquina de ensaios Instron, incidindo uma força de $2,5 \mathrm{~mm} /$ minuto, num ângulo de $30^{\circ} \mathrm{com}$ a cúspide vestibular, até que a fratura ocorresse. Após 24 horas, o grupo com resina adesiva apresentou maior resistência à fratura que o grupo com Copalite. Porém, após a realização de termociclagem, 500 dias de estocagem ou realização de ciclagem mecânica, não foi observada diferença no comportamento dos dois materiais testados, o que fez os autores concluírem que o efeito na resistência à fratura promovida pela resina adesiva é transitório, talvez devido à sorpção de água da resina, causando uma deterioração nas suas propriedades físicas.

Em 1996, ROYSE; OTT; MATHIEU ${ }^{90}$ avaliaram in vitro a microinfiltração marginal em restaurações de amálgama (Dispersalloy) associadas a adesivos dentinários e ao verniz cavitário, utilizando dentes decíduos. Foram utilizados 30 molares decíduos ou caninos, totalizando 60 cavidades confeccionadas nas faces vestibular e/ou lingual, as quais foram divididas igualmente em 3 grupos: grupo 1 adesivo Pro Bond; grupo 2 - verniz cavitário Plastodent; grupo 3 - sem material intermediário. No grupo 1, as paredes cavitárias foram condicionadas com ácido fosfórico a $37 \%$ por 60 segundos, lavadas por 30 segundos e secas, sendo que o adesivo foi aplicado e fotopolimerizado por 10 segundos, com posterior condensação e escultura do amálgama, seguida por nova fotopolimerização por 30 segundos. O verniz cavitário foi aplicado em duas camadas, sendo que cada uma delas foi deixada para secar por no mínimo 2 minutos. Após a realização das restaurações, os dentes foram armazenados por uma noite em solução fisiológica, termociclados por 1000 ciclos entre $5^{\circ} \mathrm{C}$ e $55^{\circ} \mathrm{C}$ em banhos de 30 segundos contendo solução de fucsina básica a 0,5\% e armazenados nesta mesma solução por 24 horas, sendo então seccionados. A avaliação foi realizada por 3 examinadores, através de um estereomicroscópio com 10 vezes de aumento, seguindo uma escala de escores. O adesivo Pro Bond apresentou os menores 
valores de microinfiltração marginal quando comparado aos outros grupos, sendo as diferenças estatisticamente significantes. A aplicação de duas camadas de verniz cavitário diminuiu a penetração do corante quando comparado ao grupo sem material intermediário.

ÖLMEZ; CULA; ULUSU76, em 1997, realizaram um estudo in vivo para avaliar a performance clínica e a microinfiltração marginal de restaurações de amálgama e de resina associadas ao adesivo Amalgambond Plus em dentina profunda de dentes decíduos. Foram selecionadas 25 crianças com 6 a 9 anos de idade, que possuíam molares decíduos simétricos com cavidades MOD ou VOL amplas. As cavidades foram preparadas e, quando havia necessidade, uma base de cimento de hidróxido de cálcio era aplicada. O Amalgambond Plus foi aplicado de acordo com as instruções do fabricante, seguido da inserção da resina composta (Superlux) ou do amálgama (Alloyx) em cavidades simétricas de um mesmo paciente. As restaurações foram acompanhadas e observadas após 3 meses, 15 meses, 2 e 3 anos, observando a adaptação marginal, cárie secundária, sensibilidade pós-operatória e retenção. O estudo de microinfiltração marginal foi realizado através da extração dos dentes em sua época de exfoliação, obtendo-se um total de 29 restaurações. Os dentes foram imersos em solução alcoólica de azul de metileno a 1,25\% por 24 horas, seccionados e avaliados através de um microscópio binocular para classificação da penetração do corante através de escores. Das 50 restaurações realizadas, 45 foram observadas clinicamente após 15 meses, 38 após 2 anos e 34 após 3 anos, sendo que não houve diferença entre as restaurações de amálgama e de resina composta nos períodos avaliados. Quanto à avaliação da microinfiltração marginal in vitro também não foi observada diferença entre os dois materiais. Os autores concluíram que o Amalgambond Plus é um agente adesivo que fornece bons resultados em cavidades amplas em dentes decíduos, restauradas tanto com amálgama como com resina composta.

Em 1997, ROULET ${ }^{89}$ publicou um trabalho com o intuito de apresentar as vantagens e desvantagens dos materiais estéticos adesivos que poderiam substituir o amálgama em dentes posteriores. Os possíveis materiais que poderiam substituir o amálgama são as restaurações diretas com resina composta e "inlays" de resina composta ou porcelana. As resinas compostas diretas ainda possuem restrições em relação às restaurações de amálgama pelo desgaste superficial e pelo comportamento marginal, devido à contração de polimerização, além de 
necessitarem de um tempo clínico aproximadamente 2,5 vezes maior. Para cavidades mais amplas, a utilização de "inlays" é a melhor alternativa. Numa análise de estudos que relatam a longevidade de cada técnica, o autor observou que o amálgama apresenta excelentes resultados, superiores a 20 anos, sendo a média de falhas anuais de 0,3 a 6,9\%. As resinas compostas possuem uma variação de falhas semelhante $(0,5-6,6 \%)$, porém com o tempo de estudo bem menor (máximo de 10 anos). Já as "inlays” possuem um menor número de dados na literatura, sendo a longevidade prevista maior que 6 anos, com falhas anuais de 0,6 a 5\%. Como conclusão, o autor afirma que as alternativas estéticas ao amálgama requerem procedimentos mais complexos e um maior tempo clínico. Se a relação custo benefício for considerada, o amálgama é ainda o material restaurador mais conveniente para dentes posteriores.

PINTO $^{82}$, em 1997, avaliou in vitro, a capacidade de diferentes materiais aplicados entre a estrutura dentária e o material restaurador em promover o vedamento marginal. Foram considerados dois tempos de armazenagem (1 e 6 meses) e a localização das margens cavitárias (esmalte na oclusal e cemento na cervical). Os materiais intermediários testados foram os adesivos dentinários AllBond 2 + Liner F e o Scotchbond Multi Uso Plus, o CIV Vitremer, o cimento resinoso Panavia 21 e, como controle, um grupo com verniz Copalite. Foram utilizados 70 molares humanos hígidos, os quais foram divididos em 10 grupos, sendo que cada dente recebeu duas cavidades classe $\mathrm{V}$, totalizando 140 cavidades. Todos os materiais resinosos foram aplicados de acordo com as instruções do fabricante e o verniz Copalite, aplicado em duas camadas, sendo a primeira seguida de um leve jato de ar por 5 segundos. O Vitremer foi manipulado de acordo com as instruções do fabricante, inserido na cavidade com auxílio de um pincel e o amálgama foi condensado sobre o material ainda em fase plástica. O amálgama Dispersalloy foi condensado manualmente logo após a colocação dos materiais intermediários, sendo polido uma semana depois. As amostras foram armazenadas em solução salina a $0,9 \%$ em temperatura de $37^{\circ} \mathrm{C}$ durante os períodos de tempo préestabelecidos, sendo submetidos a ciclagens térmicas mensais em água, nas temperaturas de 5 e $55^{\circ} \mathrm{C}$, com 15 segundos em cada banho, totalizando 500 ciclos. Posteriormente, os dentes foram armazenados em fucsina básica a 0,5\% por 24 horas, seccionados longitudinalmente e 0 corte que apresentou maior microinfiltração marginal foi fotografado com aumento de 40 vezes, sendo então 
classificado de acordo com escores. O grau de microinfiltração marginal não foi alterado pelo tempo de armazenagem dos dentes, com exceção das margens oclusais do grupo controle que mostraram um aumento da penetração do corante após um período de 6 meses. A microinfiltração marginal foi maior nas margens em cemento, sendo que o All - Bond 2 + Liner F e o Vitremer se mostraram significantemente melhores que o Panavia 21, que apresentou os piores resultados. Nas margens em esmalte, todos os materiais apresentaram comportamento semelhante, sem diferença estatisticamente significante entre eles. A autora concluiu que não havia vantagem do uso de materiais adesivos em comparação ao uso do verniz cavitário.

Em 1997, PEREIRA JUNIOR ${ }^{79}$ realizou um estudo in vitro com o objetivo de avaliar a microinfiltração marginal ocorrida com o sistema adesivo All Bond 2 + Resinomer, com o CIV Vitrebond sem polimerização e com o verniz cavitário Copalite, em restaurações de amálgama (Dispesalloy). Foram utilizados 45 prémolares humanos íntegros e extraídos, nos quais foram preparadas cavidades classe II nas faces mesial e distal, com a parede cervical localizada $1 \mathrm{~mm}$ além da junção cemento-esmalte. Após a realização das restaurações, os dentes foram armazenados em água destilada por 24 horas, termociclados em água nas temperaturas de 5 e $55^{\circ} \mathrm{C}$, com banhos de 15 segundos, por 500 ciclos e imersos em solução de fucsina básica a $0,5 \%$ por 24 horas, em uma temperatura de $37^{\circ} \mathrm{C}$. Os espécimes foram seccionados e a microinfiltração marginal avaliada através de um microscópio óptico com aumento de 30 vezes, através do qual eram obtidas as medidas lineares da penetração do corante na parede cervical. Observou-se que houve diferença estatisticamente entre os dois grupos experimentais e o grupo controle (verniz), assim como entre os dois experimentais, sendo os melhores resultados obtidos com o All Bond 2 associado ao Resinomer.

Também com o objetivo de avaliar in vitro a microinfiltração marginal em restaurações de amálgama, OLIVEIRA ${ }^{75}$, em 1997, realizou um estudo no qual foram testados o verniz cavitário Copalite e os adesivos dentinários Scotchbond Multi Uso Plus e Multi Bond Alpha. Foram utilizados 45 pré-molares humanos hígidos e extraídos, nos quais foram preparadas cavidades classe II, sendo uma na face mesial e a outra na distal, com a parece cervical localizada $1 \mathrm{~mm}$ além da junção amelo-cementária. Após a aplicação dos agentes intermediários, a cavidade foi restaurada com o amálgama Dispersalloy. Decorridas 24 horas de armazenagem 
em água a $37^{\circ} \mathrm{C}$, os dentes foram termociclados em água nas temperaturas de $5 \mathrm{e}$ $55^{\circ} \mathrm{C}$, com 15 segundos em cada banho, num total de 500 ciclos, sendo então armazenados em solução de fucsina básica a 0,5\% por 24 horas, em temperatura de $37^{\circ} \mathrm{C}$. Após o seccionamento, as fatias foram avaliadas através de dois métodos: por escores, utilizando slides em aumento de 40 vezes, e por medidas lineares, em um microscópio óptico com aumento de 30 vezes. Nenhum dos materiais foi capaz de eliminar a microinfiltração marginal, sendo que os adesivos apresentaram um grau de penetração do corante significantemente menor que o verniz cavitário, sendo os melhores resultados obtidos com o Multi Bond Alpha. Além disso, verificou-se que o método de medidas lineares é mais sensível que o outro método de avaliação, já que mostrou haver diferença estatisticamente significante entre os 3 grupos de estudo.

Em 1997, TJAN et al. ${ }^{102}$ compararam a efetividade de dois CIV, sendo um convencional (Fuji Duet) e um reforçado por partículas metálicas (Amalcoden), de um adesivo (Amalgambond) e um verniz cavitário (Copalite) no vedamento marginal de restaurações de amálgama. Foram utilizados 40 molares humanos hígidos, nos quais foram preparadas cavidades cilíndricas na superfície oclusal, com $5 \mathrm{~mm}$ de diâmetro e 2,5mm de profundidade. Os dentes foram divididos igualmente em 4 grupos de acordo com o material forrador aplicado e as restaurações foram realizadas com o amálgama Contour, que é uma liga com alto conteúdo de cobre. $\mathrm{O}$ amálgama foi condensado sobre o CIV ainda em fase plástica. Os espécimes foram armazenados em água destilada a $37^{\circ} \mathrm{C}$ por 7 dias, termociclados nas temperaturas de $5^{\circ} \mathrm{C}$ e $55^{\circ} \mathrm{C}$ por 300 ciclos com banhos de 30 segundos e imersos em solução de fucsina básica a 0,5\% por 24 horas. Após este período, os mesmos foram seccionados longitudinalmente em três fatias e a avaliação da microinfiltração marginal foi realizada através de um exame de todas as fatias em um microscópio com aumento de 100 vezes, de acordo com escores. Os resultados indicaram que não houve diferença estatisticamente significante entre os grupos que receberam o Amalcoden, Fuji Duet ou Amalgambond. Porém, os mesmos tiveram um comportamento superior ao obtido com o verniz cavitário, sendo esta diferença estatisticamente significante.

Em 1997, DEIEFENDERFER; REINHARDT ${ }^{36}$ compararam a resistência de união ao cizalhamento do amálgama à dentina usando duas ligas de amálgama e cinco resinas adesivas. Foram utilizados 100 molares humanos extraídos, nos quais 
foi realizada uma planificação da superfície oclusal com lixas até a exposição da dentina, que foi posteriormente polida com lixas 240, 400 e 600. Esta superfície foi tratada com um dos seguintes materiais adesivos: All-Bond 2, Amalgambond Plus, Amalgambond Plus / HPA, Optibond e Resinomer. As ligas de amálgama utilizadas foram Tytin e Dispersalloy, condensadas manualmente nas cavidades com auxílio de uma matriz de teflon. As amostras foram estocadas por 7 a 10 dias em água destilada a $37^{\circ} \mathrm{C}$, termocicladas por 300 ciclos nas temperaturas de $5^{\circ} \mathrm{C}$ e $55^{\circ} \mathrm{C}$, com banhos de 30 segundos e novamente estocadas em água destilada a $37^{\circ} \mathrm{C}$ por 36 horas. Os testes de cizalhamento foram realizados em uma máquina de ensaios Zwick, com uma velocidade de $5 \mathrm{~mm} /$ minuto. A combinação Tytin/Optibond produziu os melhores resultados de união (14,17MPa), enquanto o Dispersalloy/ Amalgambond Plus resultou nos piores valores (3,89MPa). Em geral, os sistemas adesivos com carga (Amalgambond Plus/HPA, Optibond, Resinomer) apresentaram resultados de adesão mais altos que os grupos com adesivos sem carga (All-Bond 2, Amalgambond Plus). Numa comparação entre as ligas, quatro dos cinco adesivos testados tiveram melhores resultados com Tytin do que com Dispersalloy, embora tenha havido diferença estatisticamente significante em apenas dois grupos.

Neste mesmo ano, RUZICKOVA et al. ${ }^{91}$ avaliaram o resultado clínico de restaurações adesivas de amálgama com dois anos de duração. Os sistemas adesivos testados foram o Primer A\&B e o All-Bond, em cavidades sem retenções adicionais. Foram avaliadas 137 restaurações realizadas em dentes permanentes, observando a forma anatômica das superfícies oclusal e proximal, adaptação marginal, qualidade da superfície e sensibilidade. Os resultados levaram os autores a concluírem que as restaurações de amálgama com adesivos apresentam um desempenho clínico semelhante às restaurações realizadas com amálgama sem adesivos.

BOSTON $^{24}$, em 1997, avaliou os efeitos da incorporação dos adesivos dentinários usados como bases nas restaurações de amálgama, utilizando terceiros molares humanos hígidos. Foram utilizados dois dentes no grupo controle (sem nenhuma base) e cinco nos grupos experimentais (Amalgambond Plus e All-Bond 2/Resinomer), sendo que os mesmos receberam cavidades classe I e foram restaurados com a liga Dispersalloy. Após a realização das restaurações, os dentes foram seccionados vertical e horizontalmente, sendo avaliados através de radiografias digitalizadas, com auxílio de um microscópio. Há uma grande 
incorporação de adesivo na massa do amálgama. $\mathrm{Na}$ análise dos cortes verticais, observou-se que a incorporação do adesivo ocorre em camadas, de acordo com os incrementos de amálgama condensados. Através dos cortes horizontais, pôde-se observar que, no nível oclusal, a restauração é aparentemente livre de incorporações ou defeitos. Ambos os adesivos testados incorporaram-se no amálgama, levando o autor a sugerir que são necessários estudos para avaliar a conseqüência desse fato.

Ainda em 1997, BELCHER; STEWART ${ }^{12}$ avaliaram restaurações de amálgama adesivo por um período de dois anos, através de um estudo clínico. No total, participaram do estudo 45 pacientes com molares e pré-molares que necessitavam de restaurações complexas de amálgama associadas a pinos de retenção. Os dentes foram divididos igualmente em três grupos: grupo 1 - preparo convencional (remoção de estrutura dentária comprometida ou sem suporte) e pinos de retenção (Link Plus pins); grupo 2 - preparos conservadores (manutenção de estrutura dentária sem suporte) e adesivo Amalgambond Plus sem HPA; grupo 3 idem ao grupo 2, porém com adesivo Amalgambond Plus com HPA. A liga de amálgama selecionada foi a Dispersalloy e as restaurações foram avaliadas após um e dois anos, analisando os seguintes aspectos: retenção e reforço da estrutura dentária, sensibilidade pós-operatória adaptação marginal e recorrência de cárie. Os autores observaram resultados satisfatórios em todos os grupos, sem qualquer sinal de sensibilidade pós-operatória, fraturas marginais, perda da restauração ou cárie recorrente. Os autores concluíram que esta técnica torna possível a manutenção de estrutura dentária com suporte questionável, resultando em um preparo cavitário mais conservador. Porém, salientam que o período de 2 anos não é suficiente para garantir o sucesso deste tipo de restauração em comparação ao uso de pinos de retenção.

Com o objetivo de avaliar diferentes meios para prevenir ou evitar desmineralização das margens de esmalte em restaurações de amálgama, PIMENTA et al. ${ }^{81}$, em 1998, realizaram um estudo in vitro, utilizando 12 terceiros molares humanos hígidos e extraídos. Após limpeza e estocagem dos dentes em solução de formalina a $10 \%$ a $4^{\circ} \mathrm{C}$, por 4 semanas, foram preparadas 6 cavidades no terço médio de cada coroa, com $2 \mathrm{~mm}$ de diâmetro por $3 \mathrm{~mm}$ de profundidade. Foram realizados 5 tratamentos experimentais e um controle, todos restaurados com amálgama (Dispersalloy). Os grupos experimentais foram: grupo 1 - somente 
amálgama; grupo 2 - duas camadas de verniz Copalite; grupo 3 - flúor fosfato acidulado a 1,23\% por 4 minutos, remoção de seus excessos com papel absorvente e secagem da superfície com jato de ar; grupo 4 - adesivo Panavia Ex aplicado após condicionamento ácido com ácido fosfórico a $37 \%$ por 30 segundos; grupo 5 CIV modificado por resina Photac-Bond, numa camada de $1 \mathrm{~mm}$. O grupo controle foi restaurado somente com amálgama e não foi submetido a um ambiente de formação de cárie artificial, como realizado com os grupos experimentais. Após a realização das restaurações, os dentes foram armazenados em um umidificador por 24 horas e depois polidos com pontas abrasivas. Os dentes foram seccionados para obtenção de blocos de $4 \times 4 \mathrm{~mm}$, cada um contendo uma restauração no centro. Os mesmos foram protegidos com verniz, exceto $1 \mathrm{~mm}$ ao redor da restauração, e submetidos à ciclagem de desmineralização $(2,0 \mathrm{mmol}$ de cálcio e 2,0 mmol de fosfato em solução de $74 \mathrm{mmol}$ de acetato em pH 4,3 por 6 horas a $\left.37^{\circ} \mathrm{C}\right)$ e remineralização $(1,5 \mathrm{mmol}$ de cálcio e $0,9 \mathrm{mmol}$ de fosfato em solução de $0,1 \mathrm{mmol}$ de hidroximetil-aminometano a $\mathrm{pH} 7,0$ por 18 horas a $37^{\circ} \mathrm{C}$ ). Este procedimento foi realizado por 10 ciclos, conduzidos por 14 dias. Concomitantemente, foi realizada ciclagem térmica por 200 ciclos, com banhos de 20 segundos em $5^{\circ} \mathrm{C}, 10$ segundos em $37^{\circ} \mathrm{C}, 20$ segundos em $55^{\circ} \mathrm{C}$ e 10 segundos em $37^{\circ} \mathrm{C}$. Os espécimes foram então inclusos em resina acrílica, seccionados, polidos e avaliados através de um microdurômetro, realizando 12 indentações na parede cervical e 12 na parede oclusal do preparo. Elas se localizavam a 20,50, 100 e 200 $\mu \mathrm{m}$ de distância da margem cavitária e a 20, 40 e 60 $\mu \mathrm{m}$ da superfície externa do esmalte. Para todos os grupos, a microdureza aumentou significantemente quando as indentações eram realizadas a 20 e $60 \mu \mathrm{m}$. $\mathrm{O}$ grupo controle apresentou os valores mais altos de microdureza em todas as profundidades, seguido pelo adesivo, flúor fosfato acidulado e cimento de ionômero de vidro, que não diferiam entre si em nenhuma das profundidades. Os piores valores foram obtidos pelo grupo com verniz, com diferenças estatisticamente significantes nas profundidades de 20 e $40 \mu \mathrm{m}$. Já a $60 \mu \mathrm{m}$, seus resultados não foram diferentes daqueles obtidos com amálgama somente ou com a aplicação de CIV. A maior perda mineral no grupo com verniz pode ter sido causada pela falta de adesão do amálgama à estrutura dentária associada à solubilidade do verniz cavitário, levando a um aumento do espaço na interface dente-restauração. 
Ainda em 1998, SEPETCIOGLU; ATAMAN $^{94}$ avaliaram, in vitro, a microinfiltração marginal obtida com um verniz cavitário (Copalite) e um adesivo dentinário (Panavia Ex) em restaurações de amálgama realizadas com uma liga com alto conteúdo de cobre (Avalloy). Foram utilizados 39 pré-molares humanos intactos e extraídos por razões ortodônticas. Na face vestibular desses dentes foi produzida uma superfície plana com disco de lixa de granulação 600 e foi confeccionado um preparo cavitário com 3mm de diâmetro. Os grupos estudados foram: grupo 1 amálgama somente; grupo 2- duas camadas de verniz Copalite; grupo 3 condicionamento com ácido fosfórico a $37 \%$ por 30 segundos, lavagem, secagem e aplicação do adesivo Panavia Ex, seguido pela cobertura com Oxyguard por 6 minutos. Após os períodos de 2 horas, 24 horas, 1 semana, 1,5 e 6 meses, a quantidade de cálcio difundido através da interface dente-restauração para um aparelho com água deionizada foi medida. Após 2 e 24 horas, o grupo 1 apresentou a maior e o grupo 3 a menor microinfiltração marginal, porém sem diferença estatisticamente significante entre os grupos. Após 1 semana e 1,5 mês, observouse diferença estatisticamente significante entre o grupo 1 e os demais. Aos 6 meses, o grupo com Panavia Ex continuou apresentando os menores resultados, sendo a diferença estatisticamente significante. Também foi verificada diferença entre os grupos 2 e 3, com melhores resultados sendo encontrados no grupo 3. Os autores concluíram que a utilização de adesivos fornece melhor vedamento marginal que a aplicação de vernizes cavitários, os quais são efetivos somente até 1,5 meses após a realização da restauração, já que, após este período, observa-se um grande aumento na microinfiltração marginal, decorrente provavelmente de dissolução, mudanças na porosidade e irregularidades do verniz.

Em 1998, KULAPONGS; MOORE; $\operatorname{COCHRAN}^{54}$ avaliaram a microinfiltração marginal em restaurações de amálgama com adesivos dentinários, utilizando marcadores fluorescentes e microscopia confocal. Foram utilizados 60 molares humanos extraídos, nos quais foram preparadas cavidades classe $\mathrm{V}$ na face vestibular, com margens oclusal em esmalte e cervical em dentina/cemento. Os dentes foram divididos em 6 grupos: grupo 1- nenhuma base; grupo 2 - adesivo One Step; grupo 3 - adesivo Clearfil Liner Bond; grupo 4 - adesivo Optibond FL; grupo 5 - adesivo Prime Bond 2.1; grupo 6 - adesivo Single Bond. Todos os adesivos foram marcados com rodamina B e a liga utilizada foi Dispersalloy. Após 48 horas da realização das restaurações, os dentes foram termociclados e armazenados por 2 
semanas em água a $37^{\circ} \mathrm{C}$, seguido por imersão em solução de fluoresceína a $0,5 \%$ por 5 minutos. Em seguida, os dentes foram seccionados longitudinalmente através do centro das restaurações e a microinfiltração marginal foi avaliada através de um microscópio confocal. Foi observada uma microinfiltração marginal mais freqüente na interface dente-adesivo, principalmente nas margens em cemento/dentina. Os autores concluíram que as restaurações de amálgama forradas com adesivo não diminuem a microinfiltração marginal quando comparadas com restaurações de amálgama adesivo. Os maiores valores de microinfiltração marginal foram encontrados com o grupo sem qualquer base e os menores valores com o grupo em que foi utilizado o Optibond FL.

Com o objetivo de avaliar a microinfiltração marginal ocorrida com 7 sistemas adesivos em restaurações de amálgama e resina composta, EVANS; NEME; HOELSCHER ${ }^{39}$, em 1998, realizaram um estudo in vitro. Foram confeccionados preparos classe $\mathrm{V}$ nas faces vestibular e lingual de 80 molares humanos, com o centro na junção amelodentinária. Os dentes foram divididos aleatoriamente em 8 grupos, sendo um controle (verniz copal e ácido fosfórico a 37\%) e 7 experimentais: Amalgambond, Clearfil Liner Bond, One-Step, Optibond FL, Prime Bond, Scotchbond MP e Tenure Quik. A face lingual foi restaurada com amálgama (Tytin), enquanto a vestibular, com resina composta (Herculite XRV). Os dentes foram submetidos à termociclagem por 500 ciclos nas temperaturas de $5^{\circ} \mathrm{C}$ e $55^{\circ} \mathrm{C}$, com banhos de 1 minuto e armazenados em solução de fucsina básica a 0,5\% por 4 horas, sendo posteriormente seccionados e avaliados através de um microscópio óptico binocular e de um sistema de imagem digitalizada no computador (Image - Pro Plus, versão 1.3), tanto na parede cervical como na oclusal. Os grupos controles apresentaram maiores valores de microinfiltração marginal que os grupos com adesivos tanto para as restaurações de amálgama como para as de resina composta. Não houve diferença entre os diferentes adesivos nas restaurações de resina composta, enquanto nas restaurações de amálgama o One-Step e o Prime Bond apresentaram uma microinfiltração marginal significantemente menor que o Tenure Quik, enquanto os outros grupos apresentaram resultados intermediários. Os adesivos dentinários diminuíram significantemente a penetração do corante total e a observada na parede cervical dos preparos restaurados com ambos os materiais, não havendo diferença na parede oclusal.

Em 1998, com o objetivo de avaliar a resistência à fratura de restaurações 
complexas de amálgama associadas a adesivos dentinários, com ou sem pinos dentinários, ROSEN; HERMESCH; SUMMITT ${ }^{87}$ realizaram um estudo in vitro, utilizando 150 molares humanos extraídos. Estes dentes foram desgastados até formar uma superfície plana $1 \mathrm{~mm}$ aquém da junção amelocementária, sendo divididos aleatoriamente em 10 grupos de 15 dentes cada: em 5 grupos foram fixados 4 pinos TMS Minim. Os materiais intermediários aplicados foram o verniz cavitário Copalite e os adesivos Optibond Solo, Scotchbond MP Plus, Resinomer e Amalgambond Plus com HPA. Após a adaptação de uma matriz ao dente e a aplicação do material segundo as instruções do fabricante, o amálgama Phasealloy foi condensado mecanicamente até a altura de $4 \mathrm{~mm}$. Os espécimes foram termociclados por 1500 ciclos, com banhos de $6^{\circ} \mathrm{C}$ e $60^{\circ} \mathrm{C}$ durante 30 segundos, sendo posteriormente armazenados em água por 1 mês. Os testes de resistência à fratura foram realizados em uma máquina de ensaios Instron, com um ângulo de $45^{\circ}$ e uma velocidade de $1 \mathrm{~mm} /$ segundo. Todos os grupos com pinos, exceto para o grupo do Resinomer, apresentaram maior resistência à fratura que os grupos sem pinos. Dentro do grupo com pinos, o Amalgambond Plus com HPA apresentou resultados superiores aos outros grupos. Quando os pinos não foram utilizados, este material também apresentou os maiores valores, porém sem diferença estatisticamente significante quanto comparado ao grupo do Resinomer. Os menores valores foram encontrados com o grupo do verniz Copalite.

Com o objetivo de avaliar a resistência de união ao cizalhamento do amálgama à dentina, utilizando adesivos dentinários de frasco único, DENEHY; COBB; VARGAS ${ }^{35}$, em 1998, realizaram um estudo in vitro. A superfície proximal de 108 terceiros molares humanos foi desgastada até a exposição de dentina, os quais foram divididos em 9 grupos, de acordo com o adesivo aplicado: Single Bond, OneStep, Optibond Solo, Prime Bond 2.1, além dos adesivos experimentais Single Bond Experimental e Prime Bond $2.1 \mathrm{w} /$ Amalgambond Acessory kit. Como controle foram utilizados os adesivos Scotchbond MP, Scotchbond MP Plus w light curing e w/o light curing. Após a restauração (Tytin), os dentes foram armazenados por 7 dias, sendo posteriormente termociclados por 300 ciclos nas temperaturas de $5^{\circ} \mathrm{C}$ e $55^{\circ} \mathrm{C}$ para a realização do teste de cizalhamento. Os adesivos Single Bond Experimental e Scotchbond MP Plus w light curing apresentaram os maiores valores de resistência de união. O adesivo Optibond Solo apresentou resultados superiores quando 
comparado aos grupos em que foram aplicados os adesivos One Step, Single Bond e Prime Bond 2.1.

Em 1998, NG; PURTON; HOOD ${ }^{74}$ avaliaram a efetividade de CIV e de adesivos resinosos na retenção de restaurações de amálgama e gálio. Foram utilizados discos de metilmetacrilato, nos quais foram confeccionados preparos cilíndricos que atravessava toda a extensão do disco, totalizando 210 espécimes, divididos em 21 grupos. Estes preparos foram forrados com um dos materias intermediários testados, aplicados de acordo com as instruções do fabricante: verniz cavitário Fuji Varnish, Vitrabond, Vitremer, All Bond 2, Resinomer e Paama 2. O verniz cavitário foi aplicado em duas camadas em todas as paredes da cavidade. $O$ Vitrabond, Vitremer e Resinomer não foram fotopolimerizados antes da condensação do amálgama e, no grupo controle, não foi aplicado qualquer material intermediário. As ligas testadas foram Permite C, Logic Plus e Galloy, todas condensadas manualmente e esculpidas após 1 minuto de espera. Os espécimes foram então armazenados em água a $37^{\circ} \mathrm{C}$ por 7 dias. $\mathrm{O}$ teste de resistência de união ao cizalhamento foi realizado em uma máquina de ensaios Instron, com uma velocidade de $5 \mathrm{~mm} /$ minuto, até que a restauração se deslocasse da cavidade preparada. $O$ padrão de fratura encontrado foi avaliado através de um microscópio binocular. Para as restaurações de Permite $C$ não hove diferença entre os grupos do verniz cavitário, Paama 2 ou All Bond 2 quando comparados com o grupo controle. Diferenças estatisticamente significantes foram encontradas entre Vitrabond, Vitremer e Resinomer quando comparados ao grupo controle. Para as restaurações de Logic Plus, houve diferença significante entre Vitrabond, Vitremer, All Bond 2 e Resinomer quando comparados ao grupo controle. Para as restaurações de Galloy, os resultados foram similares aos obtidos com o grupo do Logic Plus. A avaliação do padrão de fratura demonstrou que as restaurações com os CIV e adesivos resinosos permitem a ocorrência de falhas na interface material intermediário/material restaurador.

Com o intuito de avaliar a capacidade de redução da microinfiltração marginal em restaurações de amálgama, utilizando várias combinações de sistemas adesivos dentinários/resina viscosa, MEIERS; TURNER ${ }^{62}$, em 1998, realizaram um estudo in vitro. Foram utilizados 60 molares humanos extraídos que receberam preparos classe $\mathrm{V}$ nas superfícies mesial e distal, com 1,5mm de profundidade e parede gengival localizada a 0,5mm além da junção amelocementária. Os dentes 
foram divididos em 12 grupos que diferiam na liga de amálgama utilizada (Tytin e Dispersalloy) e no material forrador (nenhum, Copalite, Amalgambond Plus, Tenure/Panavia Ex, Syntac/Dual Cem e All-Bond 2/Liner F). Os sistemas adesivos foram aplicados de acordo com as instruções do fabricante, o verniz foi aplicado em duas camadas finas, secas por 30 segundos, e o amálgama foi condensado manualmente. Após a realização das restaurações, os espécimes foram brunidos e esculpidos, sendo posteriormente mantidos em solução fisiológica por um ano, seguido de termociclagem por 3000 ciclos em água deionizada entre $5^{\circ} \mathrm{C}$ e $55^{\circ} \mathrm{C}$, com banhos de 30 segundos cada e armazenagem em solução de fucsina básica a 0,5\% por 24 horas. Após o seccionamento dos dentes, as fatias obtidas foram avaliadas nas paredes gengival e oclusal do preparo através de um estereomicroscópio com aumento de 10 vezes, segundo um critério de escores. 0 tipo de liga utilizada - esférica ou mista - não foi um fator que influenciou na microinfiltração marginal, exceto com o Copalite, no qual a liga Tytin apresentou valores significantemente mais altos que o Dispersalloy. Nos grupos em que o Dispersalloy foi utilizado, houve maior microinfiltração marginal na parede gengival em comparação com a oclusal, exceto para o grupo Syntac/Dual Cem, que não apresentou diferença. Numa comparação entre os materiais, todos os sistemas adesivos diminuíram a microinfiltração marginal em relação aos grupos sem material forrador e Copalite, exceto o Syntac/Dual Cem. Este mesmo padrão foi encontrado no grupo restaurado com Tytin. Comparando estes resultados de um ano de armazenagem com os obtidos em um outro estudo realizado pelos mesmos autores, com armazenagem de 4 dias, não foi observada diferença na microinfiltração marginal entre os diferentes grupos, exceto nos grupos sem forramento e Copalite restaurados com Dispersalloy, que apresentaram valores menores após um ano e no grupo Tenure/Panavia Ex restaurados com Tytin, que apresentou valores maiores de microinfiltração marginal após um ano. Os autores concluíram que o vedamento marginal produzido pela corrosão das ligas com alto conteúdo de cobre não é tão eficaz quanto aquele promovido pelos agentes adesivos. Esta diferença nos resultados entre o Tytin e o Dispersalloy pode ser explicada pelo padrão de corrosão das duas ligas, já que a primeira consiste em uma liga de fase única que forma os produtos de corrosão $\mathrm{CuO}_{2}$ e $\mathrm{CuC}_{12}$ mais lentamente que a liga de fase dispersa.

MARCHIORI et al. ${ }^{60}$, em 1998, avaliaram a microinfiltração marginal em restaurações de amálgama forradas com diferentes materiais. Foram utilizados 50 
pré-molares humanos extraídos e hígidos, nos quais foram preparadas cavidades classe II MOD com broca carbide $\mathrm{n}-56$, sendo que a abertura na superfície oclusal correspondeu a 1/3 da distância entre as cúspides, as paredes axial e pulpar ficaram localizadas $0,5 \mathrm{~mm}$ em dentina. Uma das caixas proximais se localizava a $2 \mathrm{~mm}$ aquém e a outra $2 \mathrm{~mm}$ além da junção cemento-esmalte. Os dentes foram divididos em 5 grupos de 10 dentes cada: grupo 1 - adesivo All-Bond 2 e Liner F; grupo 2 Flúor fosfato acidulado a 1,23\% Odahcam, aplicado por 2 minutos, com remoção dos excessos com bolinha de algodão e secagem; grupo 3 - verniz cavitário Copalite, aplicado em duas camadas, sendo que a primeira foi seca por jatos de ar e a segunda foi deixada secar; grupo 4 - CIV Vitrebond segundo as instruções do fabricante, evitando sua exposição nas margens da cavidade; grupo 5 - controle (sem proteção). A liga utilizada foi Dispersalloy, condensada manualmente e esculpida. Os espécimes foram armazenados por 24 horas em solução salina à temperatura ambiente e termociclados por 1000 ciclos nas temperaturas de $37^{\circ} \mathrm{C}$ por 5 minutos, $5^{\circ} \mathrm{C}$ por 5 segundos, $37^{\circ} \mathrm{C}$ por 5 minutos e $55^{\circ} \mathrm{C}$ por 5 segundos em banhos contendo água destilada misturada com fucsina básica a 0,5\%. Após seccionamento dos dentes no sentido mesio-distal através do centro da restauração, as fatias foram avaliadas em um estereomicroscópio com aumento de 20 vezes, classificando a microinfiltração marginal da parede gengival de acordo com escores. Em esmalte, o CIV e o grupo controle apresentaram os melhores resultados, enquanto os piores foram obtidos com os grupo do verniz e do flúor fosfato acidulado. Em dentina, o melhor resultado foi obtido com o CIV e os piores também com o verniz e o flúor fosfato acidulado. Os autores concluíram que as ligas de amálgama com alto conteúdo de cobre, de fase dispersa, são capazes de minimizar a microinfiltração marginal na parede gengival em restaurações MOD.

Em 1999, SETCOS; STANINEC; WILSON $^{95}$ realizaram uma revisão de literatura sobre os materiais utilizados para restaurações adesivas de amálgama. Eles relatam que vários adesivos dentinários foram desenvolvidos, principalmente para resinas compostas. Quando eles são usados juntamente com o amálgama, a necessidade de formas de retenção e de resistência é reduzida e o selamento marginal é melhorado. Neste trabalho os autores relatam o desenvolvimento da técnica do amálgama adesivo, afirmando que uma das primeiras tentativas ocorreu em 1897, quando o cimento de fosfato de zinco foi pincelado nas margens cavitárias antes da condensação do amálgama, o que melhorou o selamento marginal e a 
retenção da restauração. Posteriormente, houve o desenvolvimento de resinas adesivas que possuíam monômeros que se uniam ao metal, tais como o 4-METATBB, existente no Superbond, e MDP, que é um componente do Panavia. Atualmente existem vários produtos que podem ser usados para unir as resinas compostas à estrutura dentária, mas poucos são desenvolvidos exclusivamente para uso com amálgama.

Em 1999, MORAIS; RODRIGUES JUNIOR; PIMENTA ${ }^{67}$ avaliaram a microinfiltração marginal em restaurações de amálgama associadas a materiais adesivos através de um método quantitativo. Foram preparadas cavidades circulares na face vestibular de 75 dentes unirradiculares hígidos, com $2 \mathrm{~mm}$ de diâmetro e $1,5 \mathrm{~mm}$ de profundidade, $3 \mathrm{~mm}$ aquém da junção cemento-esmalte. Os dentes foram divididos igualmente em 5 grupos: grupo 1 - controle (sem agente intermediário); grupo 2 - verniz cavitário Copalite; grupo 3 - cimento adesivo resinoso Panavia EX; grupo 4 - sistema adesivo hidrofílico Scotchbond MP Plus; grupo 5 - CIV modificado por resina Photac Bond, aplicado somente na parede axial. Todos os materiais foram manipulados e aplicados de acordo com as instruções do fabricante e o amálgama (Permite $\mathrm{C}$ ) foi condensado, sendo os espécimes armazenados a $37^{\circ} \mathrm{C}$ em ambiente com $100 \%$ de umidade por 24 horas antes do acabamento e polimento. Em seguida, foram termociclados por 500 ciclos em temperaturas de $5^{\circ} \mathrm{C}$ e $55^{\circ} \mathrm{C}$, com banhos de 1 minuto e imersos em solução de azul de metileno a $2 \%$ por 24 horas, na temperatura de $37^{\circ} \mathrm{C}$, sendo então seccionados no centro da restauração para padronizar o volume de dente usado na análise de espectrofotometria. Observou-se uma microinfiltração marginal significantemente menor com o Scotchbond MP Plus, seguido pelo CIV Photac Bond, pelo Panavia EX, verniz Copalite e pelo grupo controle, sendo que foram observadas diferenças estatisticamente significantes entre todos os grupos.

Com o objetivo de avaliar a microinfiltração marginal em restaurações de amálgama associadas a diferentes materiais intermediários, AL-JAZAIRY; LOUKA², em 1999, realizaram um estudo in vitro, utilizando 24 terceiros molares humanos extraídos e hígidos. Estes dentes foram divididos em 4 grupos experimentais com 6 espécimes cada, de acordo com o material intermediário aplicado: grupo 1 - apenas amálgama (Dispersalloy); grupo 2 - verniz cavitário Copalite; grupo 3 - sistema adesivo All Bond 2; grupo 4 - sistema adesivo Amalgambond Plus. As coroas dos dentes foram conectadas a um dispositivo que mantinha solução fisiológica 
associada a azul de metileno sob pressão no interior da câmara pulpar. Através do azul de metileno era possível visualizar e fotografar o padrão de microinfiltração marginal. Foram preparadas cavidades cilíndricas oclusais em dentina, com 3mm de diâmetro e 3,5 a 4,0mm de profundidade. Após a aplicação dos materiais intermediários, o amálgama foi condensado, brunido e esculpido, e os espécimes foram amazenados em solução salina a $37^{\circ} \mathrm{C}$. Até este momento, a pressão exercida na câmara pulpar era de zero, apenas para manter a hidratação da dentina. Através do dispositivo utilizado, pôde-se quantificar a microinfiltração marginal $\left(\mu \mathrm{l} /\right.$ minuto/cm $\left.\mathrm{H}_{2} \mathrm{O}\right)$ após 24 horas, 1 semana e 1, 3 e 6 meses da realização da restauração. Decorridas 24 horas, as restaurações sem forramento apresentaram uma microinfiltração marginal significantemente mais alta que os outros grupos. Após 1 semana, as restaurações com adesivos tiveram valores significantemente menores que os outros grupos. Após 1 mês, quase todos os grupos apresentaram um aumento na microinfiltração marginal, sendo que os grupos com material intermediário tiveram resultados estatisticamente diferentes e menores que os observados no grupo controle. Após 3 e 6 meses, os grupos com adesivo apresentaram valores de microinfiltração marginal menores que o grupo controle e o grupo com verniz cavitário. Os autores concluíram que os sistemas adesivos reduziram significantemente a microinfiltração marginal em relação aos grupo com verniz Copalite ou sem material intermediário e que não houve diferença entre os adesivos nos diferentes períodos estudados.

Em 1999, PALMER et al. ${ }^{77}$ realizaram um estudo in vitro para avaliar a resistência à fratura de restaurações de amálgama classe II associadas a sete diferentes materiais: três CIV modificados por resina (Fuji II LC, Vitrebond e Vitremer), um compômero (Variglass VLC), dois CIV convencionais (Ketac Bond e Glaslonomer Cement) e um cimento de hidróxido de cálcio (Dycal). Foram utilizados 80 molares humanos superiores que foram armazenados em solução de formalina a $10 \%$ e tiveram sua superfície oclusal planificada $5 \mathrm{~mm}$ aquém da junção cementoesmalte após serem montados em uma base de acrílico. Todos os dentes receberam preparos classe II (MO ou DO) padronizados e foram divididos igualmente em 14 grupos experimentais e dois grupos controle (sem material intermediário). Além desta divisão, os materiais forradores também foram agrupados em três grupos, de acordo com o seu módulo de elasticidade: alto (controle), intermediário (Ketac Bond e Glass lonomer) e baixo (Dycal, Vitremer, Vitrebond, Fuji 
II LC e Variglass VLC). Todos os materiais foram aplicados com uma espessura de $0,5 \mathrm{~mm}$ na caixa proximal, seguido da fotopolimerização, quando necessário. O amálgama (Tytin) foi condensado manualmente com auxílio de uma porta-matriz e posteriormente esculpido. Metade dos espécimes foi mantido em ambiente com $100 \%$ de umidade a $37^{\circ} \mathrm{C}$ por 1 hora e a outra metade por um período de 7 dias, sendo posteriormente testado em uma máquina de ensaios Instron, com uma velocidade de $3 \mathrm{~mm} /$ minuto, com uma angulação de $10^{\circ}$ em relação ao longo eixo do dente, até a que houvesse fratura da restauração. Não houve diferença entre os grupos experimentais e o grupo controle nos dois intervalos de tempo testados. Houve diferença estatisticamente significante quando foram comparadas as resistências após 1 hora e 7 dias, com os espécimes testados no segundo período apresentando maiores valores. Não houve diferença entre os grupos quando separados de acordo com o módulo de elasticidade. Os autores concluíram que uma base forradora de $0,5 \mathrm{~mm}$ aplicada na caixa proximal não enfraquece a restauração de amálgama classe II.

Ainda neste ano, GORDAN et al. ${ }^{44}$ realizaram um estudo clínico para avaliar a sensibilidade pós-operatória reportada por pacientes que receberam restaurações de amálgama classe I ou II. Foram selecionados apenas dentes que ainda não tinham sido tratados e que não apresentavam qualquer sensibilidade antes da realização da restauração, totalizando 76 dentes, divididos igualmente em 4 grupos: grupo 1 - sem proteção; grupo 2 - duas camadas de verniz cavitário Copalite; grupo 3 - adesivo dentinário Scotchbond MP; grupo 4 - CIV modificado por resina forrador Fuji Bond LC. Todas as restaurações foram realizadas sob isolamento absoluto, sendo utilizada a liga de fase dispersa Original, a qual foi condensada, esculpida e brunida. Após 2 e 7 dias da realização das restaurações, os pacientes foram questionados quanto à existência ou não de sensibilidade, sua causa, duração e intensidade, sendo que este fator foi quantificado através de uma escala (nenhuma sensibilidade, leve, moderada ou severa). Se houvesse sensibilidade após 7 dias, os pacientes eram também contactados após 14, 30 e 90 dias para avaliar o grau de sensibilidade. Após 2 dias não houve diferença entre os grupos avaliados e após 7 dias, verificou-se que nenhum dente do grupo 4 apresentou sensibilidade. Após 14 dias, 22\% das restaurações do grupo 2 e 17\% dos grupo 3 apresentavam sensibilidade, enquanto os dentes dos grupos 1 e 4 não apresentavam esta reação. Após 30 dias, a sensibilidade foi reduzida, mas dois 
dentes do grupo 3 e um dente do grupo 2 ainda apresentavam sensibilidade. Após 90 dias não foi observada qualquer persistência destes sintomas. Quanto à duração da sensibilidade, nos grupos 2 e 3 ela perdurou por alguns segundos e para o grupo 1 perdurou por até 30 minutos, após o período de 7 dias. Após 14 dias, a sensibilidade durou alguns segundos para os dentes dos grupos 2 e 3 . Não foi observada diferença entre os grupos quanto ao grau e quanto à causa da sensibilidade. $O$ fator desencadeante de sensibilidade mais relatado foi o frio.

No ano 2000, SETCOS; STANINEC; WILSON ${ }^{96}$ realizaram uma revisão de literatura sobre as restaurações de amálgama adesivo. Segundo os autores, um grande número de estudos clínicos e laboratoriais foram realizados nos últimos 15 anos com o intuito de explorar as possíveis vantagens das restaurações de amálgama aderidas às superfícies dentárias. A resistência de união relatada varia de 2 a 20MPa, com valores mais altos obtidos com adesivos com carga. Esta resistência tem sido comparada à obtida com o uso de retenções mecânicas, como sulcos de retenção. Muitos estudos que analisaram a resistência à fratura dos dentes ou a flexão cuspídea relatam uma melhora com o uso desta técnica. A maioria dos estudos concorda que o uso de adesivos resulta em uma diminuição considerável da microinfiltração marginal quando comparado a restaurações realizadas com verniz cavitário ou sem material intermediário, o que inibiria também a recorrência de cárie na interface dente-restauração. As falhas que ocorrem na interface de união geralmente são do tipo mista, predominando aquelas que ocorrem entre a resina e o amálgama. Os estudos in vitro têm demonstrado que ocorre incorporação do adesivo na massa do amálgama, o que pode causar uma diminuição da resistência da restauração. Segundo os autores, os estudos clínicos realizados até agora são de curta duração e eles demonstram que não há problemas com estas restaurações quando preparos tradicionais são realizados. Porém, vantagens também não foram observadas, exceto por alguns estudos que mostram que restaurações de amálgama adesivo podem ser úteis para casos em que restaurações tradicionais de amálgama seriam perdidas, geralmente devido a preparos com pouca ou nenhuma retenção mecânica. Os autores concluíram que, ao mesmo tempo que existem vários estudos in vitro que demonstram que as restaurações de amálgama adesivo oferecem vantagens quanto à melhora na retenção, reforço da estrutura dentária, diminuição da microinfiltração marginal e cárie secundária, a técnica operatória torna-se mais complicada e sensível, havendo 
poucas vantagens quando comparada às restaurações de amálgama tradicionais, em que o preparo oferece características retentivas.

Há evidências de que a inclusão de adesivo na massa do amálgama durante a condensação pode diminuir a resistência à tração diametral, a qual é proporcional à quantidade de adesivo incorporado. As cavidades pequenas têm uma alta proporção de área de superfície por volume se comparadas às cavidades extensas, havendo, então, maior incorporação de adesivo nas menores cavidades. Com o intuito de avaliar o efeito do tamanho da restauração na resistência à fratura de restaurações de amálgama associadas ao adesivo Amalgambond Plus com HPA, LINDEMUTH; HAGGE; BROOME ${ }^{55}$, em 2000, realizaram um estudo in vitro. Foram utilizados 60 terceiros molares humanos extraídos de tamanho similar, que foram divididos inicialmente em dois grupos de 30 dentes cada, de acordo com o tamanho da cavidade (pequena ou extensa). Os preparos próximo-oclusais pequenos foram realizados com uma broca 245, assumindo uma leve convergência para oclusal e com uma largura no istmo de $0,8 \mathrm{~mm}$. Os preparos extensos foram realizados de acordo com os preparos clássicos próximo-oclusais de Black, com a confecção de caixas proximais abrangendo 1/3 da distância entre as cúspides vestibular e lingual, sendo utilizadas as brocas 331L e 169L. Após a adaptação da matriz, em 15 dentes o adesivo foi aplicado e o amálgama (Tytin) condensado mecanicamente, enquanto nos outros 15 não foi aplicado qualquer material intermediário, sendo o amálgama condensado diretamente contra as paredes cavitárias. Os espécimes foram armazenados em água destilada a $37^{\circ} \mathrm{C}$ por 24 horas, sendo então termociclados nas temperaturas de $5^{\circ} \mathrm{C}$ e $55^{\circ} \mathrm{C}$, num total de 1000 ciclos, com 1 minuto em cada banho. Após este procedimento os mesmos foram novamente armazenados em água destilada por um período de uma a três semanas e testados em uma máquina de ensaios Instron, com uma velocidade de $5 \mathrm{~mm} / \mathrm{minuto}$ até a fratura do amálgama. As porções fraturadas foram também avaliadas em um microscópio com 10 vezes de aumento. As restaurações pequenas com adesivo apresentaram resistência à fratura significantemente maior que aquelas sem este material. Já as restaurações extensas não foram influenciadas pela presença do adesivo e não foram observadas outras diferenças entre os grupos. Quanto aos padrões de fratura observados, notou-se que as pequenas restaurações sem adesivo deslocavam-se inteiramente da cavidade, enquanto aquelas com adesivo apresentavam três padrões: pequenos fragmentos de amálgama no esmalte periférico; fratura oblíqua da massa do 
amálgama; deslocamento total da restauração. Todas as restaurações extensas fraturaram obliquamente na massa do amálgama, com parte do material aderido nas paredes axial, vestibular, lingual ou gengival do preparo.

\subsection{VARIÁVEIS QUE PODEM INFLUENCIAR NOS TESTES DE MICROINFILTRAÇÃO MARGINAL}

\section{Em 1952, NELSEN; WOLCOTT; PAFFENBARGER ${ }^{70}$ já se preocupavam} com a existência da microinfiltração marginal e realizaram uma revisão de literatura a respeito da troca de fluidos nas margens das restaurações dentárias, salientando que a diferença no coeficiente de expansão térmica entre a estrutura dentária e os diferentes materiais restauradores pode causar a percolação marginal. Os autores concluíram que as mudanças nas temperaturas do dente e das restaurações na boca causam uma movimentação de fluidos na interface dente-restauração, causada pela diferença do coeficiente de expansão térmica e pela expansão térmica do fluido que ocupa as fendas marginais. Os autores suspeitaram que a percolação marginal poderia ser a causa de cárie recorrente nas margens da restauração e afirmaram que eram necessários estudos adicionais para esclarecer o papel da percolação marginal na eficiência dos materiais restauradores.

Em 1976, KIDD ${ }^{51}$ realizou uma revisão de literatura sobre os diversos métodos de avaliação da microinfiltração marginal, tanto in vivo como in vitro, que incluíam o uso de corantes orgânicos, isótopos radioativos, ar pressurizado, bactérias, análise de ativação de nêutron, cárie artificial e microscopia eletrônica. De acordo com a autora, a utilização de corantes orgânicos é uma das técnicas mais antigas e mais utilizadas para se detectar microinfiltração em testes de laboratório. Além disso, ela salienta a importância da realização da ciclagem térmica nestes testes, já que pode haver diferença no coeficiente de expansão térmica entre a estrutura dentária e os materiais restauradores, causando uma percolação marginal.

Em 1978, LUND; MATTHEWS; MILLER ${ }^{56}$ avaliaram o número necessário de camadas de verniz cavitário necessário para selar os túbulos dentinários, através de uma análise em MEV. A superfície vestibular de molares humanos extraídos foi desgastada até que a dentina fosse exposta, formando uma superfície plana. Os dentes foram divididos em quatro grupos: grupo 1 - controle (sem verniz); grupo 2 - 
uma camada de Copalite; grupo 3 - duas camadas de Copalite; grupo 3 - três camadas de Copalite. O verniz foi aplicado com bolinhas de algodão de aproximadamente $2 \mathrm{~mm}$ de diâmetro, seguindo as instruções do fabricante: após a limpeza e secagem da superfície, o verniz foi aplicado rapidamente sobre a superfície e seco por 30 segundos. As aplicações subseqüentes foram realizadas com intervalos de 2 minutos. Os dentes foram preparados para a avaliação em MEV e as superfícies foram fotografadas com uma câmara polaróide, com vários aumentos. No menor aumento (20x), pouca diferença foi observada entre a superfície controle e a que recebeu apenas uma camada de verniz. Já no maior aumento, no grupo controle foram observadas várias irregularidades produzidas pela ponta diamantada. Com uma camada de verniz, a superfície aparenta ser mais homogênea, com menos da metade das irregularidades observadas no grupo controle, apesar de ainda ser possível identificar a embocadura dos túbulos dentinários. Com a aplicação de duas camadas já não foi mais possível a visualização dos túbulos dentinários, fibras colágenas e outras irregularidades. A aplicação de três camadas originou uma superfície mais homogênea e mais lisa. Segundos os autores, a aplicação de duas camadas é o ideal, já que há uma espessura suficiente para bloquear o acesso aos túbulos dentinários e à polpa, além de manter uma textura superficial que permite a retenção mecânica do amálgama à cavidade, o que seria dificultado com uma superfície muito lisa.

Em 1984, BAUER; HENSON ${ }^{10}$ realizaram uma revisão de literatura a respeito da microinfiltração marginal e seu uso na avaliação da integridade marginal de materiais restauradores. Como fatores que contribuem na ocorrência da microinfiltração marginal, os autores citaram a fenda marginal, propriedades físicas inadequadas do material restaurador e técnica ou procedimento restaurador impróprio. Quanto à fenda marginal, salientaram que o principal fator a ser considerado é a sua largura, já que, para que haja penetração bacteriana, é necessário que este espaço tenha de 2 a $20 \mu \mathrm{m}$, pois as bactérias patogênicas têm cerca de $2 \mu \mathrm{m}$. Para que haja reincidência de cárie, é necessário que este espaço tenha pelo menos $50 \mu \mathrm{m}$, o que já pode ser detectado através de instrumentos odontológicos. Em relação às propriedades físicas dos materiais restauradores, devem ser considerados a solubilidade e o coeficiente de expansão térmica. A solubilidade é afetada por alimentos aderentes, higiene bucal inadequada e a 
quantidade e freqüência de ingestão de carboidratos, que podem promover uma rápida desintegração do material, principalmente na região cervical. A estrutura dentária possui um determinado coeficiente de expansão térmica $\left(11 \times 10^{-6} .{ }^{\circ} \mathrm{C}^{-1}\right)$, assim como cada material restaurador. Se o valor entre eles for similar, a microinfiltração marginal será menor. Porém, os materiais disponíveis possuem coeficientes bastante diferentes (amálgama: $22-28 \times 10^{-6} .{ }^{\circ} \mathrm{C}^{-1}$; resina composta: 26 $\left.40 \times 10^{-6} \cdot{ }^{\circ} \mathrm{C}^{-1}\right)$. Portanto, para qualquer um destes materiais, o coeficiente de expansão térmica contribui em aproximadamente $90 \%$ das trocas de fluido durante a contração e expansão com a variação de temperatura. Os 10\% restantes seriam causados pela própria expansão térmica do fluido da cavidade bucal, associado à contração de polimerização, porosidade e fratura do material. Como possíveis conseqüências da microinfiltração marginal, os autores salientam o fracasso da restauração, dissolução e alteração de cor de certos materiais, podendo ainda causar sensibilidade pós-operatória, penetração de bactérias, cárie secundária e danos pulpares. Como métodos de investigação da microinfiltração marginal são citados a visualização (direta, microscopia óptica ou MEV), ar pressurizado, corantes, isótopos, bactérias e cárie artificial, associados ou não `a termociclagem. Estes procedimentos são necessários porque submetem os materiais a situações que simulam a condição clínica, provocando um estresse na interface denterestauração, pelas diferentes temperaturas empregadas (máxima: $45-60^{\circ} \mathrm{C}$ e mínima: $4-15^{\circ} \mathrm{C}$ ). Estas são as temperaturas extremas que são normais na cavidade bucal. Quanto às restaurações de amálgama, aquelas realizadas com ligas de alto conteúdo de cobre possuem menor deterioração e corrosão, possuindo uma fenda marginal inicial extensa o suficiente para permitir a microinfiltração marginal, mas que vai diminuindo com o envelhecimento pela deposição de produtos da corrosão na interface dente-restauração.

Muitos estudos in vitro que avaliam a capacidade de vedamento marginal utilizam a ciclagem térmica para promover estresse e o envelhecimento das restaurações. Com o objetivo de avaliar diferentes técnicas de termociclagem e imersão em corante, CRIM; SWARTZ; PHILLIPS ${ }^{33}$, em 1985, testaram a microinfiltração marginal em 50 pré-molares com cavidades classe $V$ nas faces livres com margens em esmalte, sendo que elas foram restauradas com resina composta (Concise). Dois sistemas de termociclagem foram testados: I- 4 segundos em $60^{\circ} \mathrm{C}$, seguido por banhos de 23 segundos em $37^{\circ} \mathrm{C}, 4$ segundos em $12^{\circ} \mathrm{C}$ e 23 segundos 
em $37^{\circ} \mathrm{C}$, num total de 1500 ciclos; II - banhos de 30 segundos em temperaturas de $60^{\circ} \mathrm{C}$ e $12^{\circ} \mathrm{C}$, também com 1500 ciclos. Quanto às variações do uso do corante, foram estabelecidos os seguintes métodos: A - termociclagem com a técnica I, com as amostras mergulhadas em fucsina básica a 0,5\%; B - termociclagem com a técnica I, em água, e posterior armazenagem em fucsina por 24 horas; C - igual ao grupo anterior, apenas utilizando a técnica II; D - termociclagem com a técnica II e armazenagem dos espécimes em solução aquosa de $\mathrm{Ca}^{45}$ durante 2 horas; $\mathrm{E}-$ sem termociclagem e armazenagem das amostras em fucsina básica por 24 horas. Quando a fucsina foi utilizada, os espécimes foram seccionados e avaliados em microscópio com um aumento de 40 vezes, enquanto os espécimes armazenados em solução de $\mathrm{Ca}^{45}$ foram preparados para avaliação por auto-radiografias. As amostras que não sofreram termociclagem apresentaram microinfiltração marginal menor do que as outras, porém sem diferença estatisticamente significante entre as diferentes técnicas. $\mathrm{O}$ uso de solução de fucsina a $0,5 \%$ e isótopo $\mathrm{Ca}^{45}$ mostraram igual penetração na interface dente-restauração. Os autores concluíram que tanto o tempo de imersão e a imersão em corante durante ou após a realização da termociclagem não influenciam na microinfiltração marginal.

Em 1991, BEN-AMAR; CARDASH ${ }^{13}$ discutiram os fatores relacionados à formação de fendas marginais em restaurações de amálgama e resina composta e comentaram sobre o conteúdo destes espaços e sua influência na longevidades dessas restaurações. A formação das fendas ocorre pela pobre adaptação do amálgama às paredes cavitárias, com uma espaço de 2 a $25 \mu \mathrm{m}$. O material contrai após cerca de 20 minutos de sua condensação na cavidade devido à absorção de mercúrio pela liga, sofrendo também expansão e contração de acordo com a temperatura. Além disso, a manipulação do material pelo profissional também influencia a qualidade do vedamento marginal, seja durante a trituração, condensação ou polimento da restauração. Quanto aos possíveis métodos para detectar a microinfiltração, os autores citam: exame visual - detecção de descoloração marginal, presença de margens abertas detectadas por sonda exploradora; quantificação da saída de íons $(\mathrm{OH})^{-}$liberados pela base de hidróxido de cálcio sob a restauração de amálgama; utilização de corantes (azul de metileno, fucsina básica, nitrato de prata); utilização de radioisótopos $\left(\mathrm{Ca}_{45}, \mathrm{Na}_{22}, \mathrm{C}_{14}, \mathrm{~S}_{35} \mathrm{e}\right.$ $\mathrm{l}_{131}$ ) e autorradiografias; exame da penetração de bactérias; técnica do ar pressurizado e técnica da liberação de flúor de restaurações de CIV. Segundo os 
autores, alguns pesquisadores acreditam que a penetração de bactérias na interface dente-restauração é a grande responsável pelos danos pulpares que podem ocorrer, enquanto a toxicidade do material restaurador causaria apenas uma inflamação bem mais discreta. Após o preparo da cavidade, bactérias podem permanecer na "smear layer", nos túbulos dentinários, no tecido mineralizado ou na junção esmalte-dentina. Em condições favoráveis, as bactérias proliferam na "smear layer" e na fenda, sendo nutridas pelo fluido pulpar ou resquícios de saliva que persistem na cavidade. Além das bactérias que permanecem após o preparo cavitário, outras podem penetrar pela fenda nas margens cavitárias com o passar do tempo. Juntamente com as bactérias, podem também penetrar proteínas e lipídios salivares, íons solúveis, além de toxinas e produtos liberados pela placa dentária. Os autores concluíram que é difícil conseguir restaurações que não permitam a microinfiltração marginal, mas, apesar disso, elas geralmente não mostram evidência clínica ou radiográfica de lesões de cárie. São necessários mais estudos para esclarecer os fatores envolvidos na inter-relação entre invasão e colonização bacteriana sob restaurações.

Os testes em laboratório sobre adesão, tais como resistência adesiva, microinfiltração marginal e verificação de fendas marginais, estão entre os primeiros passos a serem seguidos antes de uma avaliação clínica dos sistemas restauradores adesivos. Por não haver padronização para estes testes, RETIEF ${ }^{85}$, em 1991, realizou uma revisão das diferentes variáveis envolvidas e sugeriu procedimentos padrões para sua execução em laboratório. Em sua revisão literária sobre microinfiltração, ele percebeu que a maioria dos preparos realizados eram classe $V$, com términos em esmalte e dentina ou apenas esmalte. Segundo a ADA, os testes com materiais adesivos dentinários devem ser realizados com margens somente em dentina, sem a realização de qualquer forma de retenção. Quanto à termociclagem, a maioria dos estudos utilizava no mínimo 500 ciclos, com temperaturas entre $8^{\circ} \mathrm{C}$ e $50^{\circ} \mathrm{C}$. Esta diferença na temperatura tem como objetivo permitir a avaliação da disparidade entre os coeficientes de expansão térmica entre o dente e o material restaurador. Os tempos de banho variavam de 15 segundos a 2 minutos em cada banho, sendo que o autor preconizava um tempo não superior ao primeiro por ser este o máximo que uma temperatura se sustenta na cavidade bucal. Ele ainda sugeriu que os dentes fossem ciclados nos corantes, com exceção do nitrato de prata, o qual só deve ser utilizado após este procedimento. Quanto à influência do tempo de estocagem dos dentes após a extração e da duração da 
estocagem antes da realização dos testes na adesão dos materiais à estrutura dentária, o autor também relata que existem muitas diferenças. Os meios de armazenagem usados são: formalina, cloramina, etanol, solução fisiológica, timol e azido de sódio. $\mathrm{O}$ autor salienta que a armazenagem dos dentes em etanol a $70 \%$ diminui significantemente a resistência adesiva de resinas compostas à dentina, enquanto os outros meios fornecem resultados similares. O tempo de estocagem de 2 dias ou 6 meses após a realização das restaurações não influenciou nos resultados de adesão.

Em 1992, TAYLOR; LYNCH ${ }^{101}$ realizaram uma revisão de literatura sobre as técnicas in vitro e in vivo usadas na avaliação da microinfiltração marginal em restaurações dentárias. As técnicas mais utilizadas na época faziam uso de ar pressurizado, penetração de bactérias e radioisótopos, ativação de nêutrons, estudos eletroquímicos, microscopia eletrônica de varredura, corantes químicos ou orgânicos, com ou sem ciclagens térmicas e/ou mecânicas. Os autores relataram que o uso de corantes orgânicos era o método mais aplicado por permitir um bom contraste visual entre o corante, o dente e o material restaurador, sem necessidade de reações químicas posteriores. A principal desvantagem da técnica seria a subjetividade da avaliação da penetração do corante. Existe uma grande dificuldade de comparar os diversos trabalhos realizados devido à grande variação dos métodos utilizados e à falta de padronização dos mesmos, dos vários tipos e concentrações de corante e da grande variação dos tempos e temperaturas de ciclagem térmica, entre outros. Os autores concluem afirmando que todas as técnicas são válidas e possuem vantagens e desvantagens, sendo necessário estabelecer uma metodologia única nos testes de microinfiltração, a fim de permitir uma comparação entre os diferentes testes.

O efeito do processo de termociclagem na microinfiltração marginal em restaurações de resina composta foi objeto de estudo realizado em 1992, por WENDT JUNIOR; McINNES; DICKINSON ${ }^{106}$. Foram confeccionados preparos cavitários MOD, sendo que uma das margens gengivais se localizava em cemento, enquanto a outra, em esmalte. Foram utilizados 50 molares humanos extraídos que foram restaurados com o sistema adesivo Scotchbond e pela resina composta P50. Os espécimes foram divididos igualmente em 5 grupos, de acordo com o tratamento realizado: grupo A: sem termociclagem e imersão em fucsina básica a 0,5\% por 24 horas na temperatura de $37^{\circ} \mathrm{C} \pm 1^{\circ} \mathrm{C}$; grupo $A^{\prime}$ : igual ao grupo $A$, mas com tempo de 
imersão no corante de 4 horas; grupo B: termociclagem por 250 ciclos com tempo de imersão em cada banho de 15 segundos, nas temperaturas de 5 e $50^{\circ} \mathrm{C}$ e imersão em fucsina básica a 0,5\% por 24 horas; grupo B': igual ao grupo B, mas com tempo de imersão no corante de 4 horas; grupo C: termociclagem em fucsina básica a 0,5\% por 250 ciclos com tempo de 15 segundos em cada banho nas temperaturas de 5 e $50^{\circ} \mathrm{C}$, sendo que o tempo de imersão do corante foi correspondente ao tempo de ciclagem (4 horas). Os dentes foram inclusos em resina acrílica e seccionados longitudinalmente em 3 fatias, as quais foram avaliadas em um estereomicroscópio através de uma escala numérica, calculando-se as médias para cada superfície e para cada dente. Não houve diferença nos valores de microinfiltração marginal quando a ciclagem foi realizada em água ou diretamente no corante. $O$ grupo $B$, no qual os espécimes foram termociclados e mergulhados no corante por 24 horas, apresentou maior penetração do corante que os outros grupos nas margens em esmalte, mas sem diferença estatisticamente significante. Os autores concluíram que a realização da termociclagem não aumentou, de maneira significativa, a microinfiltração marginal em restaurações de resina composta.

O meio de armazenagem dos dentes para os experimentos realizados in vitro poderia interferir nos resultados de microinfiltração marginal. Para avaliar esta influência, HALLER et al. ${ }^{46}$, em 1993, analisaram o efeito de 4 diferentes soluções de armazenagem em restaurações classe $\mathrm{V}$ de resina composta (Prisma Micro-Fine Compules) realizadas nas faces vestibular e lingual ou mesial e distal de 125 molares humanos, avaliando-se a parede gengival, localizada em esmalte e dentina ou cemento. O grupo controle foi composto por dentes utilizados imediatamente após a extração, enquanto nos grupos experimentais os mesmos foram extraídos e armazenados por 3 a 4 semanas em temperatura ambiente, numa das seguintes soluções: cloramina $1 \%$, etanol $70 \%$, formalina $10 \%$ e timol $0,1 \%$. Após a restauração, os dentes foram termociclados em água por 1440 ciclos, nas temperaturas de 5 e $55^{\circ} \mathrm{C}$, em banhos de 30 segundos e imersos em fucsina básica a $0,5 \%$ por 24 horas, em temperatura de $37^{\circ} \mathrm{C}$. Os dentes foram seccionados e o grau de penetração do corante foi classificado em escores. A utlização de formalina $10 \%$ para armazenagem dos dentes originou os menores valores de penetração do corante, com diferença estatisticamente quando comparado ao grupo controle. Já o uso de cloramina, etanol e timol teve resultados semelhantes aos encontrados nos dentes usados imediatamente após a extração. Os melhores resultados obtidos pelo 
formalina podem ter ocorrido por uma ligação cruzada entre ela e o colágeno da dentina. Como esta condição não ocorre in vivo, esta solução não deve ser utilizada para armazenagem de dentes.

Em 1994, BURROW et al. ${ }^{25}$ investigaram a influência da profundidade (superficial ou profunda) e da idade (jovem ou madura) da dentina na resistência de união de 3 sistemas adesivos: Scotchbond Multi-Uso, Superbond D-Liner e Liner Bond II. Além disso, a variação da espessura e qualidade da camada híbrida em função destas variáveis foi observada. Para a realização do estudo, foram utilizados molares humanos recém-extraídos, os quais foram divididos em dois grupos: molares jovens (indivíduos com menos de 30 anos, sendo predominantes os terceiros molares) e molares velhos (indivíduos com mais de 50 anos, sendo a extração devido à doença periodontal). Através destes dentes foram obtidos discos de dentina de aproximadamente $3 \mathrm{~mm}$ de espessura, sendo uma face correspondente à dentina próxima da junção amelodentinária (dentina superficial) e a outra correspondente à dentina localizada próxima à câmara pulpar (dentina profunda). Após a realização dos procedimentos adesivos, foi aplicada uma camada da resina composta Photo Clearfil Anterior, em ambas as faces da fatia. Os espécimes foram armazenados em água deionizada a $37^{\circ} \mathrm{C}$ por 24 ou 48 horas antes da realização dos testes de tração em uma máquina de ensaios AG 500B, com uma velocidade de $2 \mathrm{~mm} /$ minuto. As superfícies fraturadas foram analisadas posteriormente em um microscópio com aumento de 20 vezes. Os espécimes utilizados para avaliação em MEV foram obtidos da mesma maneira descrita anteriormente para o teste de adesão, porém com o uso da resina de baixa viscosidade Protect Liner. Não houve diferença estatisticamente significante no teste de adesão após 24 ou 48 horas. Houve uma uniformidade dos resultados obtidos com o Scotchbond Multi-Uso e Liner Bond II, seguidos pelo Superbond D-liner, que geralmente apresentou resultados inferiores. Os resultados obtidos com a dentina profunda foram menores que os obtidos com dentina superficial para todos os adesivos testados, tanto em dentes jovens como em dentes mais velhos, mas houve diferença estatisticamente significante somente com o uso de Superbond D-liner. Quanto ao tipo de falha, houve uma variação maior, dependendo do adesivo aplicado, sendo mais freqüente a ocorrência de falhas adesivas. A espessura da camada híbrida também variou de acordo com o adesivo aplicado, variando de $0,5 \mu \mathrm{m}$ a $5 \mu \mathrm{m}$. Geralmente os maiores valores foram obtidos com a dentina jovem- 
superficial, exceto com o uso do Scotchbond Multi-Uso, que apresentou resultados mais uniformes. Os autores concluíram que a idade e profundidade da dentina não são significativos com o uso de agentes adesivos modernos, em relação à resistência de união.

Para avaliar a influência da termociclagem e do tempo de imersão em cada banho na microinfiltração marginal em restaurações adesivas, ROSSOMANDO; WENDT JUNIOR ${ }^{88}$, em 1995, realizaram um estudo com 90 terceiros molares humanos, nos quais foram confeccionadas cavidades classe $\mathrm{V}$ com uma margem em esmalte e a outra em cemento. Os grupos estudados foram: I: amálgama Tytin + adesivo dual Liner F; II: resina composta APH + adesivo Universal Bond 3; III: resina composta Heliomolar + adesivo Syntac. Os grupos foram subdivididos em três subgrupos: A: sem termociclagem e armazenagem dos dentes em solução de fucsina básica a 0,5\% por 166 horas; B: com termociclagem em banhos de $5^{\circ} \mathrm{C}$ e $55^{\circ} \mathrm{C}$ realizados com fucsina básica a $0,5 \%$ por 5000 ciclos, em banhos de 10 segundos; C: idem ao grupo B, mas com banhos de 60 segundos. Os dentes foram seccionados e apenas as margens em cemento foram analisadas, já que as margens em esmalte apresentaram pouca penetração do corante. As fatias obtidas foram analisadas em ambas as faces em estereomicroscópio. Com as restaurações de resina composta não houve diferença estatisticamente significante entre os grupos que sofreram ou não a termociclagem. Nas restaurações de amálgama houve uma profundidade de microinfiltração significantemente menor no grupo não termociclado. Numa comparação entre os métodos de termociclagem, verificou-se que não houve diferença entre os grupos.

Numa revisão de literatura realizada por BEN-AMAR; CARDASH; JUDES $^{14}$, em 1995, foi relatado que quanto menor a fenda entre o dente e a restauração, maiores são as chances e mais rápido será o vedamento pelos produtos da corrosão do amálgama. A adaptação do material às paredes cavitárias é afetada pela proporção liga-mercúrio, plasticidade da mistura, tempo de trituração e alterações dimensionais do material, além da realização de uma boa condensação, brunidura e um bom polimento da restauração. O tipo de liga também altera o tempo necessário para o vedamento da interface dente-restauração, já que as ligas convencionais levam alguns meses, enquanto as ligas com alto conteúdo de cobre sofrem este processo em um tempo duas vezes maior. A realização de retenções agudas na cavidade limita o acesso dos condensadores, resultando em área em que 
o material se encontra mais poroso e mal adaptado. Uma condensação mais forte promoveria melhor adaptação, especialmente quando forem inseridos pequenos incrementos, até que toda a cavidade seja preenchida com excessos. As restaurações de amálgama são rodeadas por uma fenda marginal de aproximadamente $10-15 \mu \mathrm{m}$, a qual é rapidamente preenchida por fluidos bucais e bactérias. Estas bactérias, por sua vez, colonizam esta interface, criando um ambiente ácido capaz de dissolver a smear layer. Sendo assim, a remoção da smear layer com soluções de limpeza pode permitir melhor adaptação do amálgama às paredes cavitárias.

Em 1995, PASHLEY et al. ${ }^{78}$ realizaram uma revisão de literatura sobre os testes de adesão à dentina com a utilização de adesivos dentinários. Quanto ao substrato dentinário, os autores salientam que a dentina da face oclusal tende a fornecer valores de resistência adesiva menores que aquela obtida com a dentina das faces proximais ou das superfícies lisas, devido a maior variabilidade da estrutura dentinária. Além disso, a dentina pode variar de acordo com a idade do dente, a presença ou não de cárie, restauração ou lesões de abrasão. O próprio preparo dos espécimes pode influenciar nos resultados de adesão, já que alguns estudos utilizam lixas abrasivas, enquanto outros utilizam brocas carbide ou pontas diamantadas, as quais produzem superfícies diferentes e podem ter profundidades cavitárias diferentes. Um outro aspecto discutido é a presença ou não de fluido pulpar, o que diferencia testes in vivo de testes in vitro. Os testes in vitro que tentam simular uma condição in vivo lançam mão de técnicas que utilizam solução fisiológica ou plasma associado à solução fisiológica com pressão hidrostática zero ou positiva no interior da câmara pulpar. Quantos aos testes disponíveis para avaliar a resistência adesiva, ressaltam a importância e a necessidade de padronizá-los, dando maior ênfase ao aperfeiçoamento de técnicas e materiais a serem aplicados em dentina cervical esclerosada e dentina afetada por cárie, já que estes são substratos clinicamente relevantes.

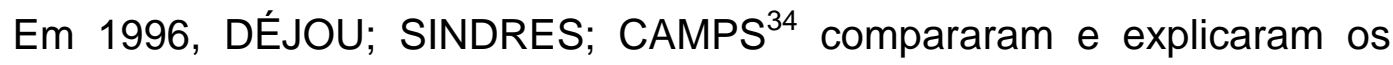
métodos estatísticos empregados para avaliação da microinfiltração marginal de sistemas restauradores em estudos in vitro. Foram utilizados 206 pré-molares humanos hígidos, os quais foram divididos em 13 grupos, de acordo com o sistema restaurador utilizado: Scotchbond/Silux; Scotchbond 2/Silux Plus; Syntac/Helioprogress; Scotchbond Multi Uso (dentina seca)/Z-100; Scotchbond Multi 
Uso (dentina úmida)/Z-100; Gluma Bond/Pekafill; Gluma 2000/Pekalux; All Bond 2 (dentina seca)/Bis Fil; All Bond 2 (dentina úmida)/Bis Fil; All Bond 2 (ataque ácido e dentina seca)/Bis Fil; All Bond 2 (ataque ácido e dentina úmida)/Bis Fil; Prisma Universal Bond 2/Prisma Fil; Prisma Universal Bond 3/Prisma Fill. Foram preparadas cavidades classe $\mathrm{V}$ na face vestibular dos dentes, com a parede gengival se estendendo até a J.C.E. Após a aplicação do sistema adesivo, a resina composta foi aplicada em dois incrementos e fotopolimerizada. Os dentes posteriormente foram armazenados em solução salina tamponada associada à penicilina-estreptomicina a $1 \%$, em temperatura de $4^{\circ} \mathrm{C}$ por 24 horas. Após este período, os dentes foram termociclados em água por 100 ciclos nas temperaturas de $5^{\circ} \mathrm{C}$ e $55^{\circ} \mathrm{C}$, com banhos de 30 segundos e armazenados em solução de fucsina básica a 0,5\% por 24 horas, em temperatura de $37^{\circ} \mathrm{C}$. Os dentes foram então seccionados para obtenção de fatias, totalizando 6 faces, as quais foram avaliadas em um microscópio óptico com aumento de 100 vezes. Foram utilizados cinco critérios de avaliação: média da penetração de corante nas 6 faces; mediana das 6 faces; moda das 6 faces; máxima penetração do corante para cada dente e porcentagem de dentes em cada grupo sem qualquer penetração do corante. Após a análise estatística dos resultados, observou-se que o número de grupos sem diferença estatisticamente significante foi maior quando o critério selecionado foi a máxima penetração do corante (6 grupos), seguido pela porcentagem de dentes sem qualquer penetração (5 grupos), moda ou média (4 grupos) e mediana (3 grupos). Dependendo do método de avaliação havia um posicionamento diferente dos 13 sistemas restauradores utilizados. Os autores concluíram que a máxima penetração do corante em cada dente parece ser o melhor método de avaliação.

Em 1996, MAHLER ${ }^{57}$ discutiu os aspectos que influenciam na interface dente-amálgama. O tipo de liga empregado é um desses fatores, já que as esféricas permitem uma microinfiltração marginal de aproximadamente 3 a 4 vezes maior que a observada com as ligas mistas. Além disso, quanto maior a plasticidade da mistura, a força de condensação, a direção da condensação contra as paredes cavitárias e a brunidura, menor será a microinfiltração marginal encontrada. A existência de fendas marginais pode originar dor pós-operatória, cárie secundária e patologia pulpar, o que pode ser minimizado com a utilização de adesivos dentinários sob a restauração. Quando duas superfícies são unidas com um agente adesivo, falhas podem ocorrer na interface entre o adesivo e os dois substratos, 
dentro dos dois substratos ou dentro do próprio adesivo. Nas restaurações de amálgama associada a adesivos, as falhas ocorrem na interface amálgama-adesivo, mas o adesivo permanece aderido ao dente, selando os túbulos dentinários. Com o tempo, os produtos da corrosão preenchem a interface entre o amálgama e o adesivo. Se o adesivo permanecer unido ao amálgama, ocorrerá uma falha na interface dente-adesivo, o que pode originar uma série de problemas: sensibilidade pós-operatória devido à falta de selamento dos túbulos dentinários, perda de resistência do dente preparado, penetração de bactérias na interface dente-adesivo e ausência de vedamento marginal pelos produtos da corrosão do amálgama neste interface. Quando o amálgama é condensado na cavidade sobre o agente adesivo parcialmente polimerizado, algumas áreas da cavidade podem ficar sem a proteção desse material. Este fato está na dependência de fatores como as características do agente adesivo, as características da reação de polimerização e a integridade da união dente-adesivo no momento da condensação do amálgama. Quanto aos estudos realizados in vivo, o autor salienta que não existem evidências dos benefícios desta técnica em restaurações classe I e II, havendo a necessidade de estudos cientificamente controlados. Além disso, há dificuldades durante a realização da técnica, já que ocorre uma adesão do adesivo no condensador e o mesmo pode se aderir às superfícies oclusal e proximal, aumentando a retenção de placa. A incorporação de adesivo na massa do amálgama pode enfraquecer a restauração, principalmente nas áreas que sofrem maior estresse, como o istmo de restaurações classe II, áreas marginais e cristas marginais. $\mathrm{O}$ autor salienta ainda 0 aumento do custo da restauração pelo próprio adesivo e pelo aumento do tempo de trabalho.

Em 1999, GALE; DARVEL ${ }^{43}$ realizaram uma revisão de literatura sobre os procedimentos de termociclagem para os testes laboratoriais de restaurações dentárias. Os autores salientam que o estresse térmico é realizado para simular um dos muitos fatores que ocorrem na cavidade bucal, sendo muito utilizado em estudos de penetração de corante, de fenda marginal e de resistência adesiva. Porém, os métodos empregados variam consideravelmente e, raramente, são realizados de acordo com observações das condições in vivo. Quanto às temperaturas verificadas na cavidade bucal, os autores afirmam que existe uma grande variação dependendo da ocasião, da pessoa e do local da cavidade bucal, além da influência da temperatura do ar, da umidade e da velocidade da respiração. Entretanto, tem-se 
observado uma temperatura de aproximadamente $35^{\circ} \mathrm{C}$ na boca. Quando alimentos ou bebidas são ingeridas, também há uma grande variação da temperatura dependendo do dente avaliado. Entre as superfícies palatinas de um incisivo e de um molar, por exemplo, há uma diferença de $4,5^{\circ} \mathrm{C}$. Quando um líquido com $60^{\circ} \mathrm{C}$ é ingerido, a superfície vestibular de um incisivo chega a $45^{\circ} \mathrm{C}$, enquanto a superfície palatina de um molar chega a $48^{\circ} \mathrm{C}$. Quando a temperatura do líquido é de $0^{\circ} \mathrm{C}$, na face vestibular do incisivo é observado um valor de $15^{\circ} \mathrm{C}$ e na superfície palatina do molar, $21^{\circ} \mathrm{C}$. Na cavidade bucal, uma temperatura de $10^{\circ} \mathrm{C}$ é tolerável, mas desconfortável. Já uma temperatura de $15^{\circ} \mathrm{C}$ não causa desconforto. Quanto às temperatura mais altas, pode-se ingerir líquidos com 60 a $68^{\circ} \mathrm{C}$, mas com desconforto. Somente com 50 a $55^{\circ} \mathrm{C}$ é possível ingerir um líquido, em grande quantidade, sem qualquer desconforto. Um líquido com temperatura de $55^{\circ} \mathrm{C}$ causa, no dente, uma temperatura de $47^{\circ} \mathrm{C}$, que é confortável desde que não permaneça na boca por mais que 15 segundos. Na revisão da literatura feita pelos autores, foram levantados 130 experimentos com termociclagem, sendo a médias de temperatura encontradas de $6,6^{\circ} \mathrm{C}$ e $55,5^{\circ} \mathrm{C}$. Destes 130 trabalhos, apenas 27 utilizaram uma temperatura intermediária de $37^{\circ} \mathrm{C}$. O número de ciclos variou de 1 a 1000000 , com uma média de 10000 e uma mediana de 500 ciclos. A duração dos banhos variou de 4 segundos a 20 minutos, com uma média de 53 segundos e mediana de 30 segundos. A efetividade deste procedimento é controversa, já que alguns trabalhos encontram diferenças entre grupos termociclados e não termociclados, enquanto outros não. Os autores recomendam que a termociclagem deve ser padronizada nos estudos e sugerem a seguinte seqüência: temperaturas de $35^{\circ} \mathrm{C}, 15^{\circ} \mathrm{C}, 35^{\circ} \mathrm{C}$ e $45^{\circ} \mathrm{C}$, com banhos de 28, 2, 28 e 2 segundos, respectivamente. Quanto ao número de ciclos, acreditam que ocorrem cerca de 20 a 50 ciclos por dia, totalizando aproximadamente 10000 ciclos por ano, o que é o recomendado pelos autores.

Com o propósito de investigar a influência da termociclagem na resistência de união de vários adesivos dentinários ao esmalte, MIYAZAKI; SATO; ONOSE $^{65}$, em 2000, realizaram um estudo in vitro. Os sistemas adesivos testados foram divididos em dois grandes grupos: sistemas de "primers self-etching" (Imperva Fluoro Bond, Clearfil Liner Bond 2, Mac Bond 2) e sistemas adesivos "self-priming" (One Step, Optibond Solo, Prime Bond 2.0 e Single Bond). Os primeiros são os sistemas que possuem um frasco com o agente para condicionamento ácido associado ao "primer" e um segundo frasco com o agente adesivo. Já os sistemas 
"self-priming" são aqueles que necessitam de um condicionamento ácido, seguido da aplicação do "primer" e adesivo em um frasco único. Foram utilizados incisivos inferiores bovinos que foram montados em resina autopolimerizante, sendo que a face vestibular foi desgastada com lixa 600. Esta superfície recebeu o adesivo de acordo com as instruções do fabricante e sobre ela foi aplicada a resina composta do mesmo fabricante do adesivo, com auxílio de um molde de teflon, seguido de fotopolimerização. Os espécimes foram divididos em 4 grupos de 10 espécimes cada: grupo 1 - estocagem em água a $37^{\circ} \mathrm{C}$ por 24 horas, sem termociclagem; grupo 2 - estocagem como no grupo 1, seguido de termociclagem nas temperaturas de $5^{\circ} \mathrm{C}$ e $60^{\circ} \mathrm{C}$ por 3000 ciclos; grupo 3 - idem ao grupo 2, mas com 10000 ciclos; grupo 4 - idem ao grupo 2, mas com termociclagem por 30000 ciclos. O tempo dos banhos da termociclagem foi de 30 segundos, com um tempo de transferência de 5 segundos. Os espécimes foram testados quanto à resistência de união ao cizalhamento em uma máquina de ensaios Instron, com uma velocidade de $1 \mathrm{~mm} /$ minuto. Após o teste, os espécimes foram examinados através de microscópio óptico com aumento de 10 vezes para definir a localização da fratura, classificando-a como falha adesiva, falha coesiva da resina composta, falha coesiva do agente de união e falha coesiva do esmalte. Também foram preparados espécimes para análise ultraestrutural da interface resina/esmalte em MEV, com um aumento de 3500 vezes. Não foi observada diferença estatisticamente significante entre os dois grupos de sistemas adesivos testados. A média de resistência de união de todos os sistemas diminuiu com o número de ciclagens, mas diferenças estatisticamente significantes foram detectadas somente com os sistemas "self-etching". O tipo de fratura predominante foi a mista, com falhas coesivas da resina e falhas adesivas nos grupos dos sistemas "self-priming" que sofreram termociclagem. Para o grupo de sistemas "self-etching", há um aumento das falhas adesivas e uma diminuição das falhas coesivas, o que tende a aumentar com o número de ciclos. Quanto à avaliação em MEV, foi observada a formação de tags de resina no esmalte rugoso pelo condicionamento ácido, no grupo dos sistemas "self-priming". Nos grupos termociclados por 30000 ciclos, pequenas falhas foram observadas na interface resina-esmalte para os sistemas "self-etching", o que não foi notado nos sistemas "self-priming". 
3 Proposição 


\section{PROPOSIÇÃO}

Neste trabalho, foram realizadas, in vitro, restaurações de amálgama (DISPERSALLOY) em cavidades classe II de pré-molares, associadas a um sistema adesivo dentinário de componente único (OPTIBOND SOLO), a um CIV modificado por resina (VITREMER) e, ainda, a um verniz cavitário convencional (COPALITE), com os seguintes objetivos:

$>$ avaliar a microinfiltração marginal ocorrida em cada um dos sistemas restauradores após ciclagem térmica, através de três diferentes métodos de avaliação de medidas lineares e,

> comparar os resultados obtidos entre si. 
4 Material e Métodos 


\section{MATERIAL E MÉTODOS}

\subsection{SELEÇÃO DOS DENTES}

Foram utilizados 45 pré-molares superiores ou inferiores extraídos por indicação ortodôntica, livres de cárie e de outros defeitos de esmalte. Após a exodontia, os restos de ligamento periodontal foram removidos delicadamente com curetas $^{a}$ afiadas e todos os dentes foram limpos com uma pasta de pedra-pomes ${ }^{b} \mathrm{e}$ água, usando escovas tipo Robinson ${ }^{c}$ montadas em contra-ângulo ${ }^{d}$ e micromotor ${ }^{d}$ para a remoção de detritos remanescentes. Uma lupa ${ }^{e}$ com ampliação de 4 vezes foi utilizada para verificar a ausência de trincas e de outros defeitos do esmalte que não seriam englobados no preparo cavitário. Os dentes que possuíam essas alterações foram excluídos do experimento e os selecionados foram armazenados em uma solução de cloreto de sódio a $0,9 \%$ e timol a $0,1 \%$ para inibir o crescimento bacteriano, sob refrigeração de aproximadamente $4^{\circ} \mathrm{C}$, até o momento da realização dos preparos cavitários.

\subsection{REALIZAÇÃO DOS PREPAROS CAVITÁRIOS}

Com o intuito de evitar a posterior penetração do corante pelo forame apical dos dentes, realizou-se o selamento do mesmo. Inicialmente, foi cortada a porção mais apical da raiz com disco de lixa de aço monoface picotado ${ }^{f}$ para possibilitar a realização de uma cavidade na superfície formada, a qual foi realizada com a broca carbide cone invertido número $329^{c}$. Posteriormente, foram aplicadas duas camadas de verniz cavitário Copalite ${ }^{g}$ e, em seguida, a cavidade foi restaurada com o amálgama Velvalloy ${ }^{b}$.

Cada dente recebeu duas cavidades classe II independentes, uma mesial

\footnotetext{
${ }^{a}$ Duflex

${ }^{b}$ S. S. White

${ }^{c}$ K.G. Sorensen

${ }^{d}$ Kavo do Brasil Ltda

${ }^{e}$ Magnifier Classic, modelo 8750G

${ }^{f}$ Adaco

${ }^{g}$ Cooley \& Cooley Ltda
} 
e outra distal, envolvendo as cristas marginais, totalizando 90 cavidades. Elas foram realizadas com broca carbide cone invertida de extremo arredondado número $245^{\mathrm{h}}$ em turbina de alta rotação' e sob refrigeração de um "spray" de ar e água. O acabamento foi realizado com a mesma broca em baixa rotação, montada em contra-ângulo e micromotor, a qual foi substituída a cada 5 preparos por uma outra sem uso, seguida pela utilização de machado para esmalte número 14-15j.

A dimensão das cavidades foi padronizada, com uma extensão de $4 \mathrm{~mm} \pm$ 0,2 no sentido vestíbulo-lingual (figura 1), dependendo do tamanho do dente, e uma profundidade de $1,5 \mathrm{~mm}$ na região da parede cervical (figura 2), no sentido axial. A extensão foi determinada com auxílio de um paquímetrok ${ }^{k}$ e a profundidade com auxílio de uma sonda periodontal. A parede cervical, plana e perpendicular ao longo eixo do dente, foi estendida $1 \mathrm{~mm}$ apicalmente, além da junção cemento-esmalte (figura 3). As paredes vestibular e lingual foram preparadas de tal forma que ficassem paralelas entre si no sentido cérvico-oclusal. Todos os ângulos internos da cavidade ficaram arredondados conforme o extremo da broca usada e não foram realizadas retenções adicionais.

\footnotetext{
${ }^{n}$ K.G. Sorensen

${ }^{i}$ Roll Air 3, Kavo do Brasil Ltda

${ }^{j}$ Duflex

${ }^{k}$ Vernier Caliper - Starfer
} 


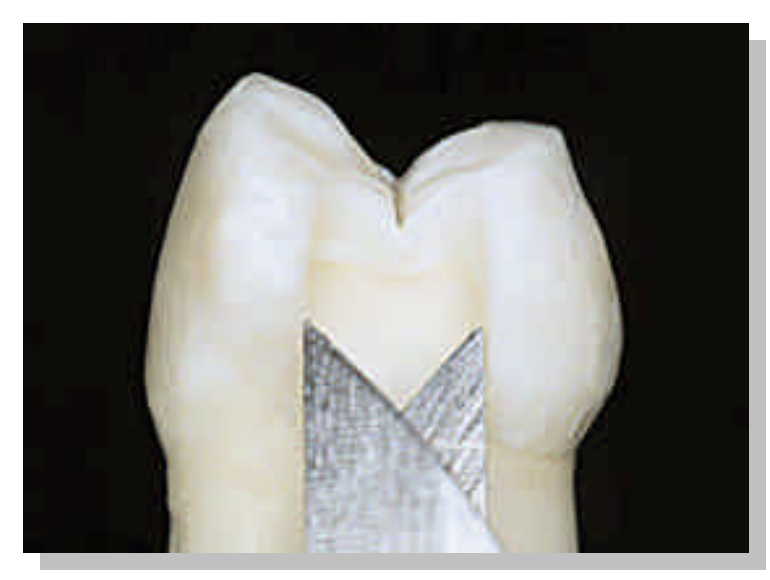

Figura 1- Extensão vestíbulo-lingual do preparo cavitário

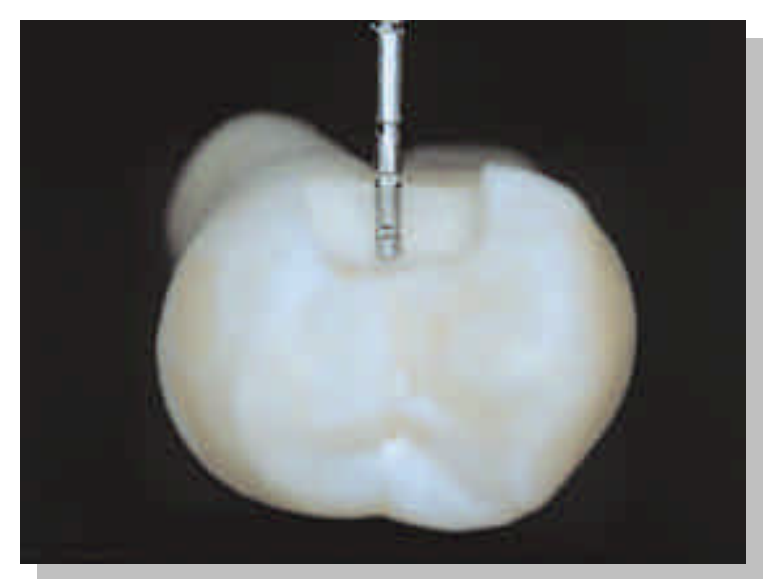

Figura 2- Profundidade do preparo cavitário

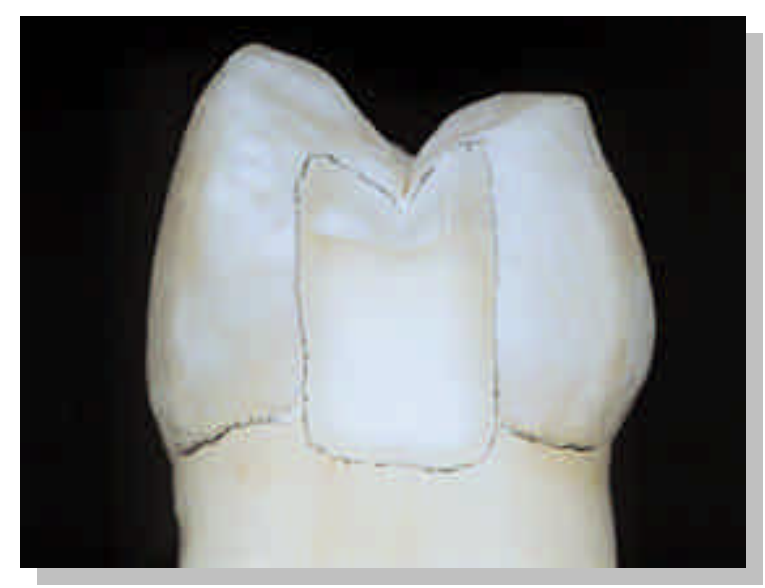

Figura 3- Limites do preparo cavitário 


\subsection{MATERIAL USADO E GRUPOS DE ESTUDO}

A escolha do material foi feita em função de alguns fatores: facilidade de obtenção; praticidade de uso, sobretudo do adesivo de componente único; possível efeito cariostático em função da presença de flúor em dois deles, e talvez ampliar a aplicabilidade do CIV VITREMER.

Previamente à aplicação dos materiais forradores, as cavidades preparadas foram limpas, friccionando-se bolinhas de algodão embebidas em água destilada, secas e novamente examinadas com a mesma lupa para verificar se existiam trincas que pudessem interferir no experimento.

Como material forrador testou-se o adesivo dentinário OPTIBOND SOLO e o CIV VITREMER. Como controle, foi usado o verniz cavitário COPALITE (figura 4).

\begin{tabular}{|c|c|c|c|}
\hline MATERIAL & FABRICANTE & LOTE & VALIDADE \\
\hline COPALITE & Cooley \& Cooley Ltda & D34F & abril - 2000 \\
\hline OPTIBOND SOLO & Kerr Corporation & 707225 & julho - 1999 \\
\hline VITREMER & 3M Dental Products & 19980930 & junho - 2000 \\
\hline DISPERSALLOY & Dentsply Ind. e Com. Ltda. & 42685 & outubro - 2003 \\
\hline K-DENT & $\begin{array}{c}\text { Quimidrol Com. Ind. Import. } \\
\text { Ltda. }\end{array}$ & 313 & julho - 2003 \\
\hline $\begin{array}{c}\text { CONDICIONADOR } \\
\text { DENTAL GEL }\end{array}$ & Dentsply Ind. e Com. Ltda. & 40661 & outubro - 2000 \\
\hline
\end{tabular}

Figura 4- Material utilizado e os respectivos dados de fabricação

Os dentes foram divididos aleatoriamente em 3 grupos de 15 pré-molares cada, diferindo apenas no forramento utilizado. As cavidades mesial e distal de um mesmo dente pertenceram a grupos diferentes para que a variável dente fosse excluída.

Os dentes a serem restaurados foram montados no centro de um bloco de gesso, sendo fixados com cera rosa $7^{\prime}$. De cada lado foi fixado um dente para simular contatos proximais. Antes do início da condensação do amálgama na cavidade, matrizes metálicas de aço inox de $7 \mathrm{~mm}^{m}$ foram previamente adaptadas e 
estabilizadas por cunhas de madeiran ${ }^{n}$. Foram utilizadas matrizes individuais compostas por uma matriz metálica perfurada em suas extremidades através de uma broca, por onde passa um fio dental ${ }^{\circ}$, o qual é amarrado promovendo a fixação da matriz ao dente (figura 5).

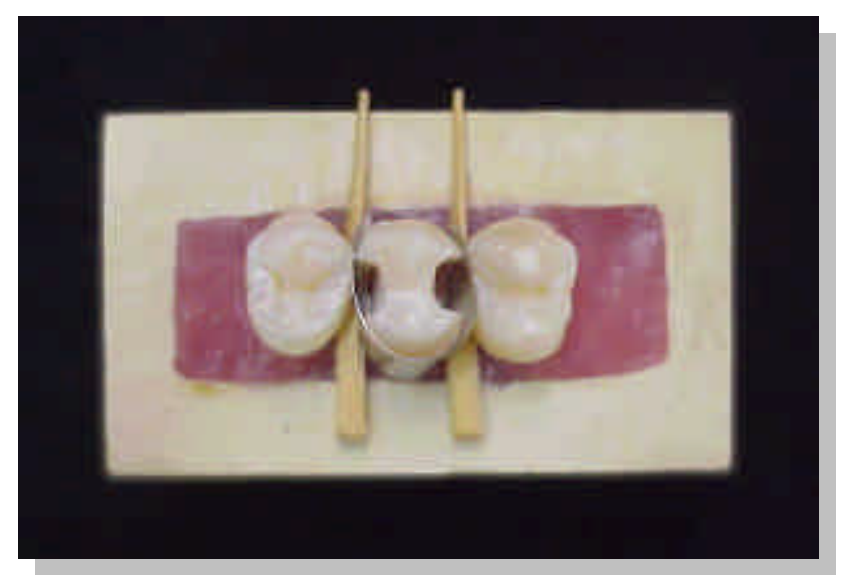

Figura 5- Dente a ser restaurado montado no bloco de gesso

Todas as cavidades foram restauradas com a liga de amálgama de fase dispersa e enriquecida por cobre DISPERSALLOY, associada ao mercúrio K-DENT (figura 6), numa proporção de 1:1. Estes materiais foram previamente pesados em uma balança de precisão ${ }^{p}$, com porções de 0,40g de cada um, o que proporcionou uma quantidade suficiente de amálgama para uma cavidade, sem muitos excessos.

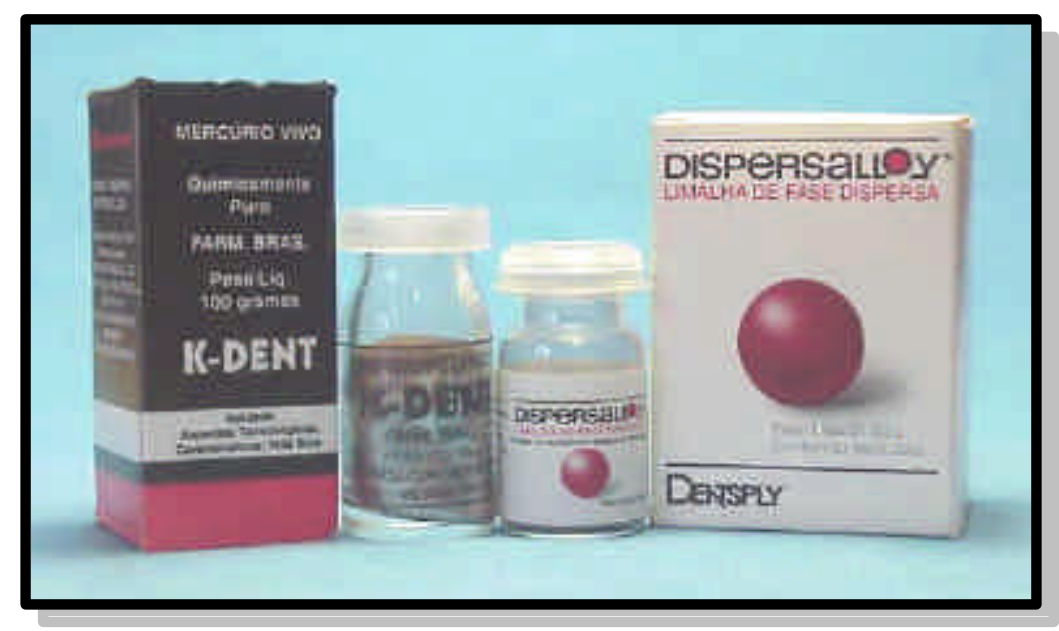

Figura 6- Liga de amálgama e mercúrio

\footnotetext{
${ }^{n}$ TDV Dental Ltda

${ }^{\circ}$ Sanifil - Facilit Odontológica e Perf. Ltda

${ }^{p}$ Micronal - 1600
} 


\section{GRUPO I - Aplicação do verniz cavitário COPALITE (GI - CP)}

O verniz cavitário COPALITE (figura 7), composto por uma resina copal dissolvida em éter e clorofórmio, foi passado com um aplicador descartável BENDA BRUSH MICRO ${ }^{q}$ em duas camadas, sendo cada uma seca através de um leve jato de ar por 30 segundos, que tem a finalidade de espalhar o verniz e evaporar o solvente. Logo após, a matriz foi adaptada e estabilizada por cunhas, sendo o amálgama condensado em seguida.

\section{GRUPO II - Aplicação do sistema adesivo OPTIBOND SOLO (GII - OS)}

Este material (figura 8) é composto basicamente por BIS-GMA, HEMA e sílica. É um adesivo de componente único designado para ser usado com resinas, metais, amálgamas e cerâmicas. Segundo o fabricante, este é um agente de união liberador de flúor, composto aproximadamente por $25 \%$ de carga, com uma combinação de sílica vaporizada e vidro de bário. No mercado, está disponível em dois conjuntos diferentes: sistema de aplicação tradicional, com 2 frascos de $5 \mathrm{ml}$, e o sistema unidose, que possui 100 unidades com $0,1 \mathrm{ml}$ cada. Neste experimento foi utilizado o sistema de aplicação tradicional, com a utilização do frasco.

As superfícies de esmalte e dentina foram condicionadas por 15 segundos com ácido fosfórico a $37 \%{ }^{r}$, lavadas vigorosamente pelo mesmo tempo e secas levemente, sem ressecar, por aproximadamente 2 segundos. Uma fina camada de adesivo foi passada através de um aplicador próprio do material, esfregando-o levemente por 15 segundos. Este procedimento elimina a necessidade de secagem com ar, segundo o fabricante. $O$ material foi fotopolimerizado por 20 segundos e logo após a matriz foi adaptada e estabilizada por cunhas para que o amálgama fosse condensado. Em todos os procedimentos em que foi necessário, utilizou-se o fotopolimerizador ULTRALUX ELETRONICs, que conferiu uma intensidade de luz de $550 \mathrm{~mW} / \mathrm{cm}^{2}$, verificada através de um radiômetrot.

\footnotetext{
${ }^{q}$ Centrix Incorporated

${ }^{r}$ Dentsply Ind. Com. Ltda.

${ }^{s}$ Dabi Atlante

${ }^{t}$ Curing Radiometer - Demetron / Kerr
} 


\section{GRUPO III - Aplicação do CIV VITREMER (GIII - VT)}

O VITREMER (figura 9) é um CIV modificado por resina, constituído por um pó, um líquido, um "primer" e um "finishing gloss”. O pó é constituído por cristais radiopacos de flúor-alumino-silicato e o líquido é uma solução aquosa de ácido polialcenóico modificado, sensível à luz. Já o "primer", também sensível à luz, possui HEMA e o "finishing gloos", BIS-GMA e TEGDMA.

Este material foi aplicado numa proporção pó : líquido de 0,25:1, ou seja, foi utilizada $1 / 4$ da medida do pó para 1 gota do líquido ${ }^{49}$, o que permitiu a obtenção de uma consistência satisfatória, possibilitando a sua aplicação como material forrador. Para facilitar e padronizar a dosagem do pó, foi confeccionado um dispositivo através de um tubete de anestésico, cujo êmbolo foi posicionado para que a quantidade correspondente a $1 / 4$ fosse obtida. Foi aplicado, então, um adesivo entre o êmbolo e a superfície do tubete, na porção posterior, para evitar que o primeiro se movimentasse com o uso.

Inicialmente, adaptou-se a matriz individual juntamente com as cunhas para que a inserção do amálgama fosse imediata à aplicação do CIV na cavidade. Aplicou-se o "primer" que acompanha o produto por 30 segundos com aplicador descartável BENDA BRUSH MICRO em todas as paredes de esmalte e dentina, seguido por uma secagem por 15 segundos e uma fotopolimerização por 20 segundos.

Antes de dispensar o pó para a mistura, o seu frasco foi agitado para descompactar as partículas. Em seguida, coletou-se o pó com o dispositivo confeccionado para este fim, seus excessos foram removidos com auxílio de uma espátula de nylon flexível $n^{\circ} 142^{u}$ e a quantidade obtida foi depositada sobre um bloco de papel que acompanha o produto. Para dispensar o líquido, o frasco foi posicionado verticalmente, com a ponta voltada para baixo, a uma distância de aproximadamente $3 \mathrm{~cm}$, já que o contato com a superfície do papel poderia interferir no tamanho da gota. Se ela possuísse bolhas, era dispensada uma nova gota e a anterior era desprezada.

A mistura foi realizada com a mesma espátula de nylon, através da incorporação do pó ao líquido, num processo chamado de aglutinação, não

\footnotetext{
" JON - Comércio de produtos odontológicos Ltda.
} 


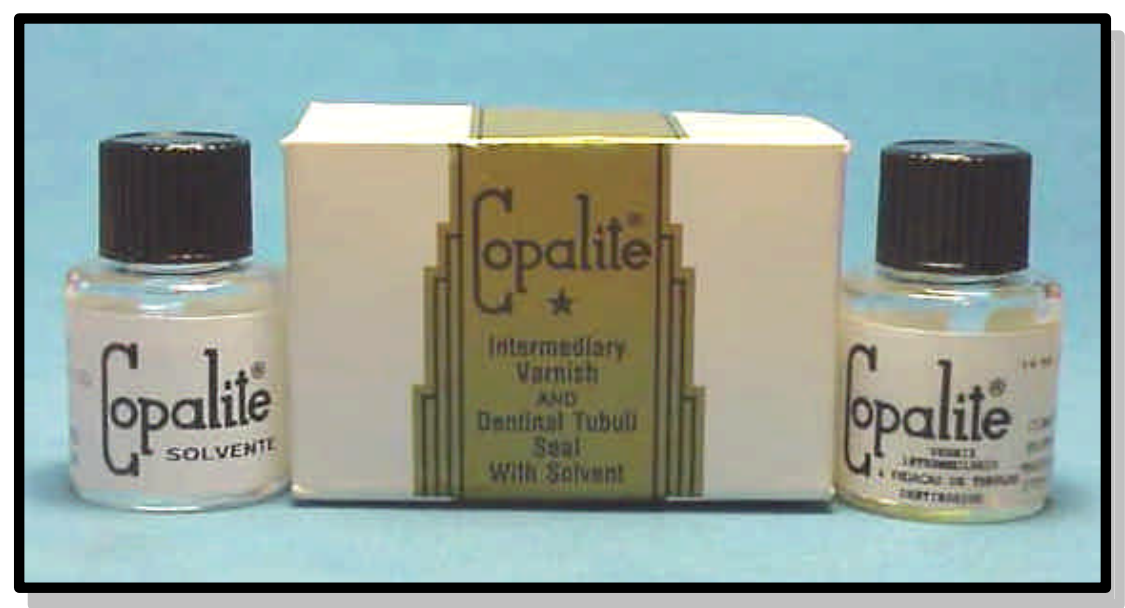

Figura 7- Verniz cavitário COPALITE

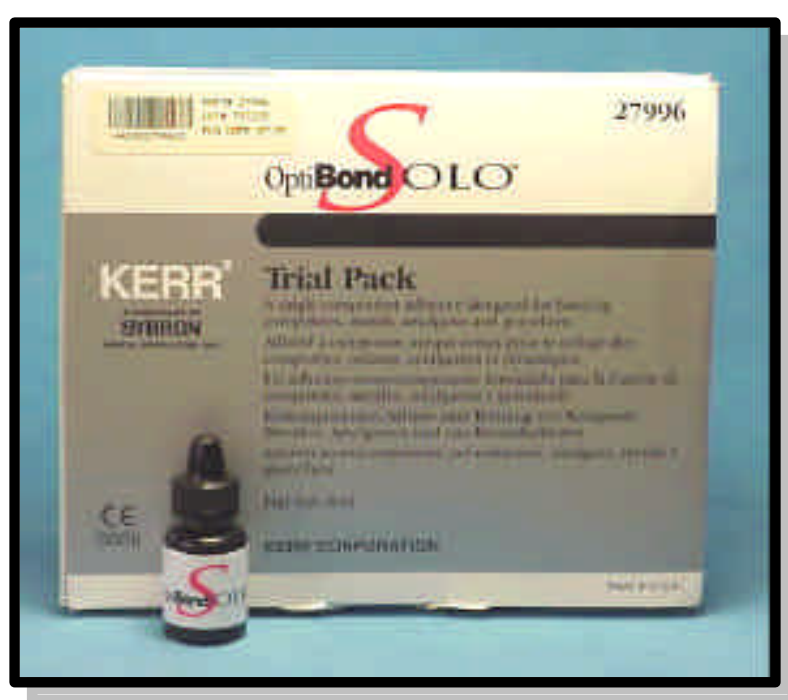

Figura 8- Sistema adesivo OPTIBOND SOLO

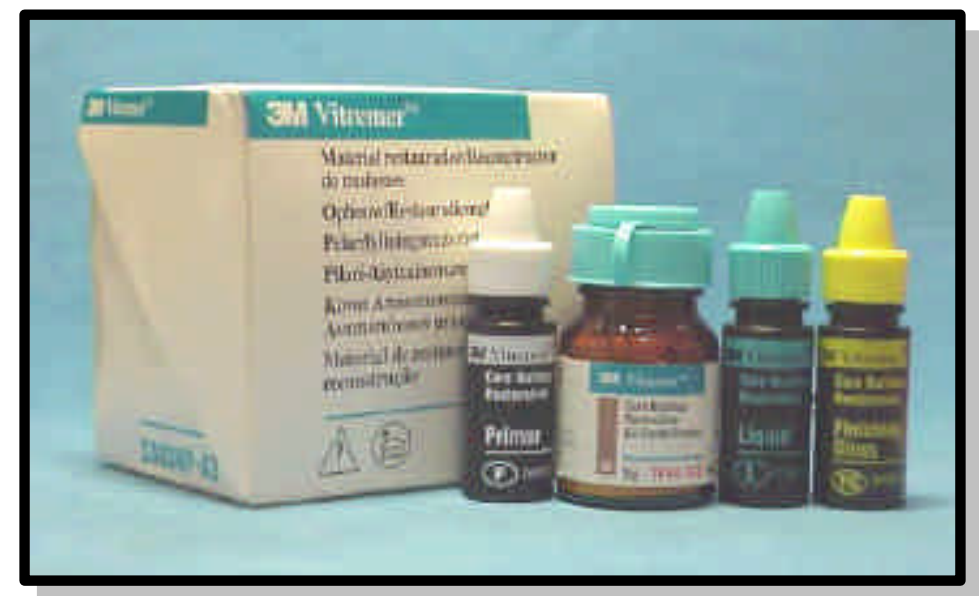

Figura 9- CIV modificado por resina VITREMER 
ultrapassando um tempo de 45 segundos. Simultaneamente, a trituração do amálgama foi realizada. Após a obtenção de uma massa homogênea, passou-se uma fina camada do material em todas as paredes de esmalte e dentina com auxílio de um aplicador descartável BENDA BRUSH MICRO, sendo o amálgama condensado imediatamente, com o CIV ainda em fase plástica. Os excessos de cimento que por ventura surgissem na margens da cavidade durante este procedimento foram removidos ainda durante a condensação.

\subsection{REALIZAÇÃO DAS RESTAURAÇÕES}

Para todos os grupos a trituração do amálgama foi mecânica, com o uso de um amalgamador calibrado do tipo cápsula CAPMASTER ${ }^{v}$, durante 10 segundos. Uma trituração complementar de 3 segundos foi realizada sem o pistilo, com o propósito de se conseguir uma massa única e mais homogênea.

Após a trituração, o amálgama foi colocado em um lençol de camurça e inserido na cavidade com um porta-amálgamaw ${ }^{w}$, em pequenas porções. A condensação foi realizada manualmente por um único operador, com um condensador $\mathrm{n}^{0} 1$ de Ward $^{x}$, preenchendo a cavidade com excesso. Em seguida, foi realizada uma brunidura com um brunidor $\mathrm{n}^{\circ} 33$ de Bennett ${ }^{x}$, com movimentos da restauração para o dente e a escultura oclusal foi feita com um instrumento manual de Hollemback $3 S^{x}$. A matriz foi removida por vestibular, através do corte do fio dental, e foram removidos os excessos da superfície proximal. Após 5 minutos foi realizado o alisamento final da restauração com uma bolinha de algodão. No GIII VT, realizou-se a fotopolimerização por 40 segundos na superfície oclusal e por mais 40 segundos na superfície proximal.

Após a realização da restauração, o dente foi removido do bloco de gesso (figura 10) e identificou-se cada face proximal de acordo com o material forrador aplicado, através de uma pincelada de esmalte para unhas ${ }^{y}$ na superfície radicular. A cor vermelha foi usada para identificar o GI - CP, a cor cinza para o Gll - OS e a cor azul para o GIII - VT.

Após a secagem do esmalte em temperatura ambiente, os espécimes

\footnotetext{
${ }^{v}$ S.S.White

${ }^{w}$ JON - Comércio de produtos odontológicos Ltda.

${ }^{x}$ Duflex

${ }^{y}$ Maybeline
} 
foram imersos em água deionizada e armazenados em uma estufa ${ }^{z}$ a $37^{\circ} \mathrm{C}$ durante 24 horas.

\subsection{TERMOCICLAGEM E PENETRAÇÃO DO CORANTE}

Antes da termociclagem, aplicou-se sobre os ápices radiculares uma camada de adesivo instantâneo universal SUPER BONDER ${ }^{a^{\prime}}$ para impedir qualquer penetração de corante pelo canal radicular. O restante da superfície dentária foi isolada com duas camadas de esmalte para unhas ${ }^{b^{\prime}}$ até $1 \mathrm{~mm}$ aquém de toda a restauração, sendo que a segunda camada foi aplicada após a secagem da primeira (figura 11). Para isso, utilizou-se a mesma cor usada para a identificação do material forrador, de tal maneira que cada metade do dente ficasse coberta por uma cor diferente de esmalte.

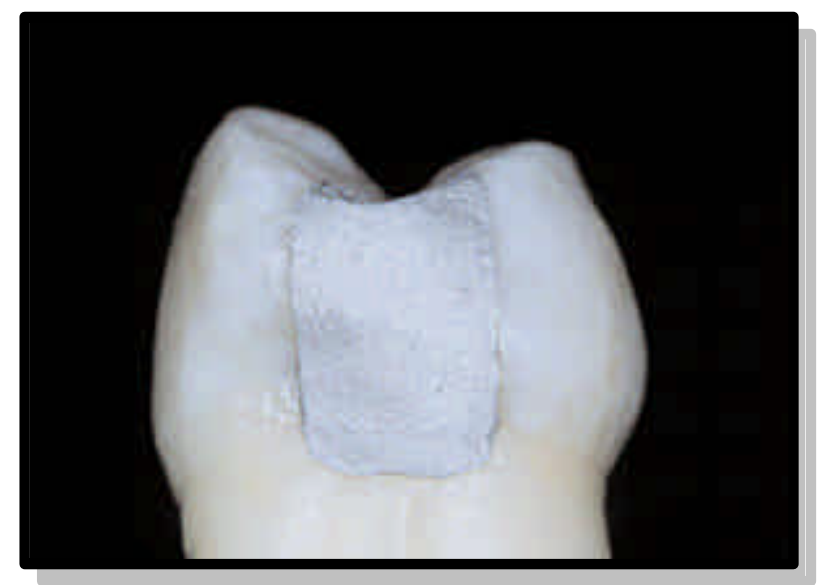

Figura 10- Restauração finalizada

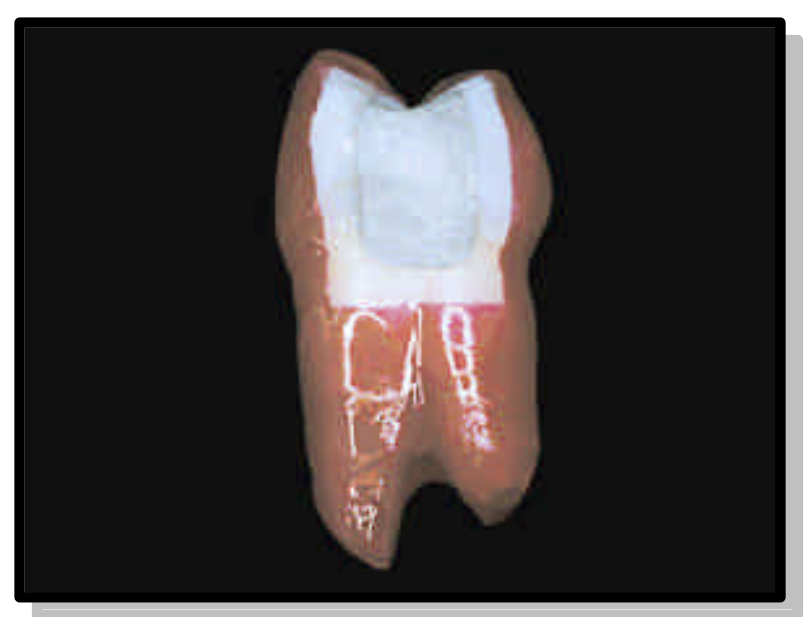

Figura 11- Espécime após a aplicação de esmalte de unhas

\footnotetext{
${ }^{z}$ Estufa de Cultura - Modelo 002 CB - Fanem Ltda.

$a^{\prime}$ Loctite Brasil Ltda

$b^{\prime}$ Maybeline
} 
Após a secagem do esmalte, os dentes foram submetidos à termociclagem em água deionizada nas temperaturas de $5^{\circ} \mathrm{C} \pm 4$ e $55^{\circ} \mathrm{C} \pm 4$, num total de 500 ciclos. Para a realização deste procedimento foram utilizadas duas cubas ${ }^{c^{\prime}}$, sendo que em uma delas seu termostato foi ligado para manter a temperatura da água em $55^{\circ} \mathrm{C}$ e na outra a temperatura de $5^{\circ} \mathrm{C}$ foi obtida e regulada através do uso de gelo.

Os dentes foram colocados em um recipiente metálico em forma de cesta, mergulhados por um tempo de 15 segundos em uma cuba e por mais 15 segundos na outra cuba, com um intervalo entre eles de aproximadamente 5 segundos para que o excesso de água escorresse do recipiente, evitando alterações da temperatura da água. Este procedimento correspondeu a 1 ciclo e foram realizados continuamente até a execução de 500 ciclos. O tempo em cada banho foi determinado através de um cronômetro e as temperaturas foram aferidas em intervalos de 10 minutos, através de um termômetro, para evitar oscilações.

Após a termociclagem, os dentes foram examinados para observar se havia alguma falha na camada de esmalte, o qual foi reaplicado, se necessário. Em seguida, os dentes foram armazenados em solução aquosa de fucsina básica a $0,5 \%$, durante 24 horas, em estufa a $37^{\circ} \mathrm{C}$.

Decorrido o tempo de imersão, os dentes foram lavados em água corrente durante 24 horas para a remoção do excesso superficial do corante.

\subsection{REALIZAÇÃO DOS SECCIONAMENTOS}

Após a lavagem dos dentes, o esmalte superficial foi removido com instrumento manual de Hollemback 3S, já que sua coloração encontrava-se alterada devido ao corante. Uma nova camada de esmalte foi aplicada, utilizando-se as cores padronizadas para cada material forrador, para que fosse possível identificar, na avaliação, a que grupo o espécime pertencia.

Para a realização dos seccionamentos, os dentes foram incluídos em resina ortoftálica. Os dentes inicialmente foram fixados em lâminas de cera utilidade $^{d^{\prime}}$, com a superfície vestibular voltada para a cera, para que os cortes

\footnotetext{
$c^{\prime}$ Modelo 102/n.2 - Fanem

$d^{\prime \prime}$ Horus
} 
fossem realizados no sentido mesio-distal, através das restaurações. Em seguida, canos de $\mathrm{PVC}^{e^{\prime}}$ foram também fixados na cera, envolvendo os dentes. Estes canos possuíam um diâmetro de $3 / 4$ de polegada e foram cortados com $3 \mathrm{~cm}$ de comprimento, sendo previamente vaselinados internamente para facilitar a remoção da resina após seu endurecimento. Esta foi obtida através da mistura de $170 \mathrm{ml}$ de Resapol T208 $^{f^{\prime}}$ com $20 \mathrm{ml}$ de monômero de estireno ${ }^{g^{\prime}}$. Posteriormente, foram acrescentadas e misturadas 3 medidas (tampa do frasco) de pó de resina acrílica termopolimerizável incolor até a obtenção de uma massa homogênea. Em seguida, 2 gotas de acelerador de cobalto ${ }^{f}$ foram misturadas por 1 minuto e, por fim, 30 gotas de Luperox $\mathrm{DDM}^{f^{\prime}}$ também foram misturadas por 1 minuto. Depois de 30 segundos, a resina foi vertida nos canos, incluindo os dentes.

Após 24 horas, os canos de PVC foram removidos e os dentes incluídos na resina foram seccionados no sentido mésio-distal por um disco de diamante de 0,30mm de diâmetro, em uma máquina de corte de precisão $\mathrm{EXCET}^{h^{\prime}}$ (figura 12), sob refrigeração de água e numa rotação de aproximadamente 320 RPM.

\subsection{AVALIAÇÃO DA MICROINFILTRAÇÃO MARGINAL}

Foram obtidas, em média, 4 fatias de $1 \mathrm{~mm}$ de espessura de cada dente (figura 13). Cada fatia foi avaliada em ambas as faces, originando aproximadamente 8 faces ou 16 interfaces dente-restauração a serem avaliadas por dente.

A microinfiltração marginal foi avaliada através de 3 métodos diferentes de obtenção de medidas lineares, sendo que em cada um foram realizadas 3 leituras de cada espécime, em momentos diferentes, por um examinador calibrado previamente.

Ao final, foi calculada a média aritmética dos valores obtidos em cada uma das 3 leituras, separadamente para cada método de avaliação, sendo os dados tabulados posteriormente.

\footnotetext{
$e^{\prime}$ Tigre

${ }^{f}$ Redefibra Com. de produtos para Fiberglass Ltda.

${ }^{\prime}$ Reforplás Ind. e Com. Ltda.

$h^{\prime}$ Modelo 1010 - Excel Technologies
} 


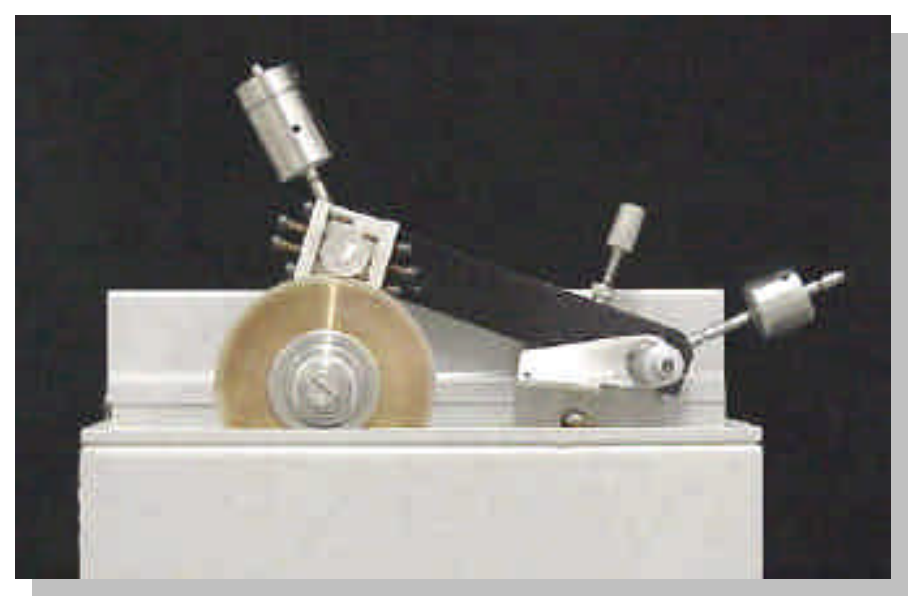

Figura 12- Espécime montado para a realização dos seccionamentos

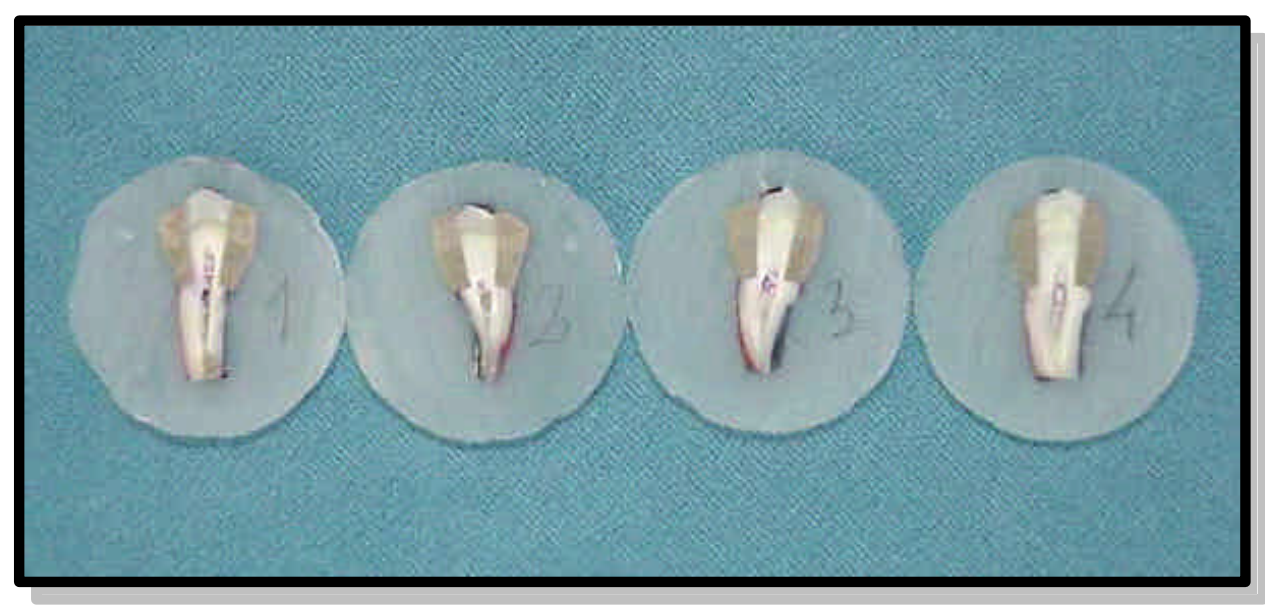

Figura 13- Conjunto de fatias obtidas através do seccionamento de um dente

\subsubsection{Avaliação pelo microscópio}

Foi realizada através de um microscópio óptico ${ }^{i}$ que fornece medidas em milímetros, com um aumento de 150 vezes.

Em seu visor há dois retículos perpendiculares entre si, sendo um vertical e o outro horizontal, para orientação na tomada das medidas. O retículo vertical foi posicionado paralelamente à face externa da restauração e o horizontal o mais próximo possível e paralelo à parede cervical da cavidade. Nesta posição, o valor obtido no microscópio foi considerado zero e, em seguida, o retículo vertical foi posicionado até atingir o ponto máximo de penetração do corante na parede 
cervical, obtendo-se o valor da extensão de penetração do corante (figura 14). Quando houve penetração do corante nos túbulos dentinários da parede axial, a leitura foi realizada até a intersecção entre o retículo vertical e o limite da área infiltrada, mantendo o retículo horizontal em sua posição padrão.

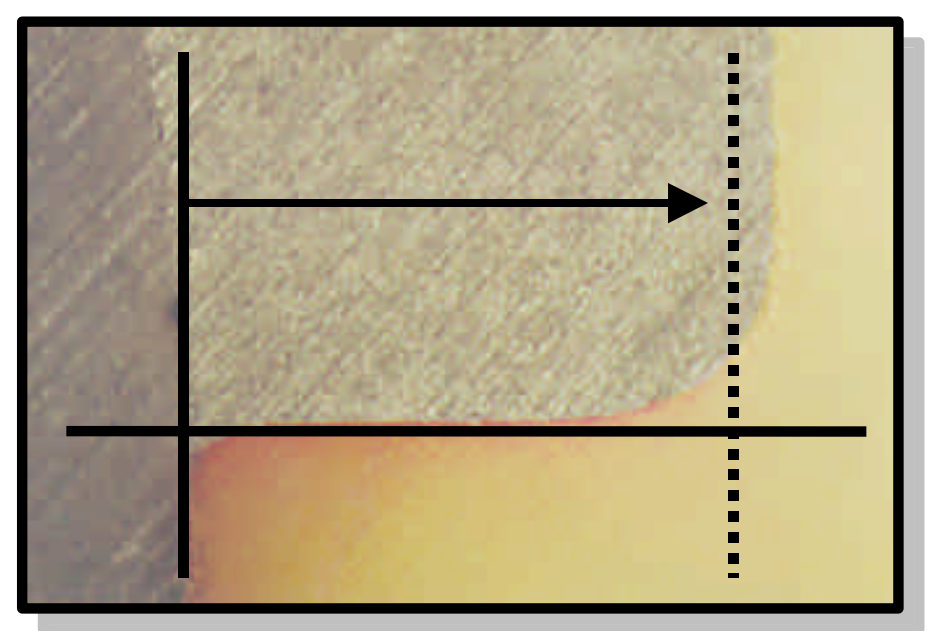

Figura 14- Medida da microinfiltração marginal pelo microscópio

\subsubsection{Avaliação pelo software - medidas em linha reta única (Sigma única)}

Inicialmente, a imagem de cada face das fatias obtidas de um dente e a imagem de uma escala milimetrada foram captadas em um "scanner" de mesa $\mathrm{j}^{\text {", }}$ localizado nas dependências da biblioteca da FOB-USP. Para tal foi utilizado o software Adobe Photoshop, captando a imagem através do caminho TWAIN 32. Foi utilizada uma resolução de $600 \mathrm{dpi}$, com um brilho de 115 e um contraste de 145 , sendo que as imagens foram salvas como arquivos do tipo JEPG, com qualidade máxima, no nível 10 e armazenadas em disquetes de $3,5^{\prime \prime}{ }^{\prime}$. Em cada disquete foi possível salvar 2 imagens, sendo que cada uma correspondia a um lado de uma mesma fatia.

Posteriormente, foi utilizado um computador' para medir a profundidade de penetração do corante, através de um software ${ }^{m}{ }^{\prime}$, que possibilita a mensuração de distâncias ou áreas, entre outras. As imagens foram abertas do disquete para a tela do monitor e o software foi padronizado para a avaliação. No ícone measure foi escolhido o caminho trace measure options, que fornece todos os tipos de medida

\footnotetext{
'ScanJet 4C - Hewlett Packard

$k^{\prime}$ Sony - Sony Eletronics

${ }^{\prime}$ Pentium $200 \mathrm{MHZ}$ - Intel, monitor SyncMaster 500b - Sansung

$m^{\prime}$ Sigma Scan, versão 2.0 - Jandel Corporation
} 
que podem ser realizadas pelo programa. No caso deste trabalho, foi utilizada a opção distância. No mesmo ícone measure, no caminho calibrate distance and area, foi realizada a transformação das distâncias obtidas em pixels para milímetros, utilizando a opção 2 point-rescaling. Na imagem já aberta, o primeiro ponto correspondeu ao traço referente a $0 \mathrm{~cm}$ e o segundo ao traço de $1 \mathrm{~cm}$ da escala milimetrada. O valor referente ao old distance foi de 238,000 "pixels", o que corresponde, então, a $10 \mathrm{~mm}$ no new distance. No quadro $X Y$ and distance units foi digitada a unidade milímetros.

Para realizar a medida da microinfiltração marginal, foi utilizada a função régua + lápis no ícone régua. A imagem das faces foi aumentada em 4 vezes, através das teclas $\mathrm{Ctrl}+1$, para melhor visualização da interface dente-restauração. Um aumento muito maior dificultava a avaliação, pois os "pixels" tornavam-se muito visíveis, o que alterava toda a imagem. Nesse aumento, o cursor foi localizado no ângulo cavosuperficial da cavidade, na parede cervical, indicando o ponto inicial da tomada da distância percorrida pela microinfiltração marginal do corante. A partir dele, a imagem foi percorrida em linha reta na interface dente-restauração da parede cervical ou além da parede axial, conforme descrito anteriormente, até o ponto máximo de penetração do corante (figura 15). Através do ícone tabela, as medidas obtidas em milímetros foram anotadas.

\subsubsection{Avaliação pelo software - medidas em linhas segmentadas (Sigma segm.)}

Para a realização desta análise, foi utilizada a mesma metodologia descrita anteriormente, diferindo apenas na tomada da extensão da microinfiltração marginal. O cursor foi inicialmente localizado na interface dente-restauração e foram definidas linhas segmentadas percorrendo toda a extensão da penetração do corante, acompanhando possíveis irregularidades das paredes cervical e também da axial (figura 16). 


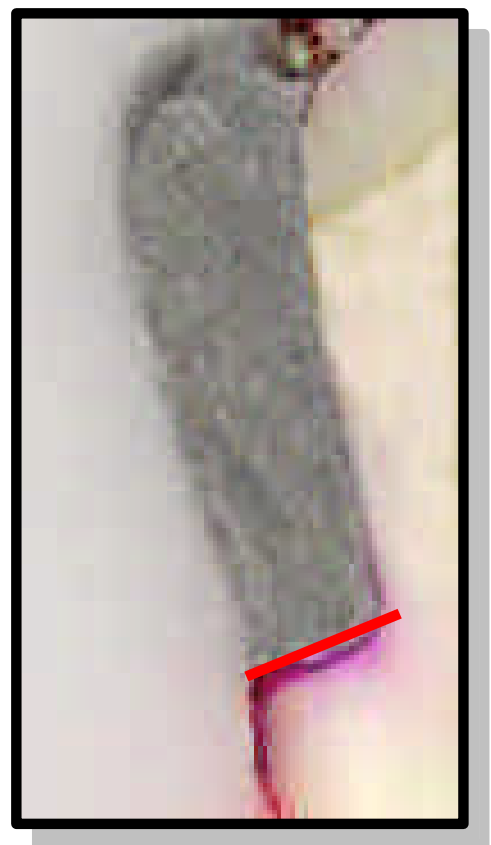

Figura 15- Medida da microinfiltração marginal pelo método Sigma única

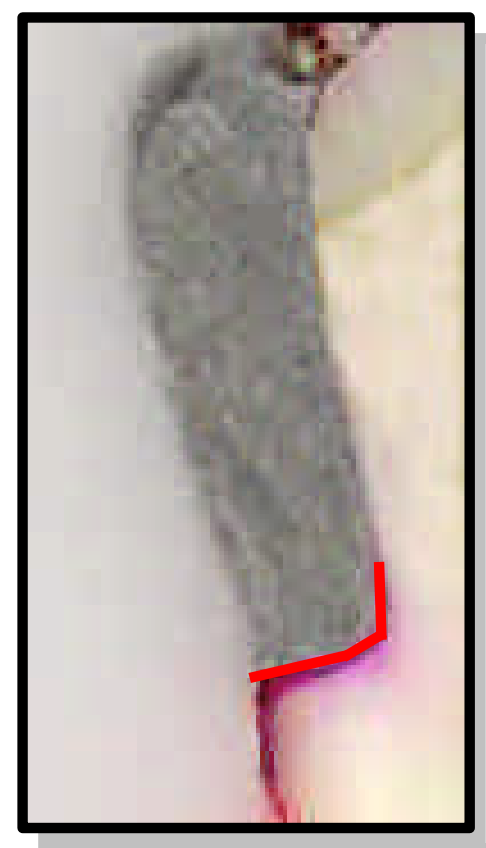

Figura 16- Medida da microinfiltração marginal pelo método Sigma segm. 
5 Resultados 


\section{RESULTADOS}

Ao se considerar na análise dos resultados ambas as faces de cada fatia da restauração, foram obtidos 184 espécimes no Gl - CP, 202 no Gll - OS e 196 no GIII - VT. Durante a realização dos seccionamentos, três espécimes do GI - CP e um do Gll - OS foram perdidos porque a restauração deslocou-se da cavidade.

Para cada um dos métodos de avaliação realizou-se três leituras da microinfiltração marginal por face, de cada fatia, obtendo-se então uma média aritmética da face. De posse desses dados, calculou-se, em seguida, a média aritmética da microinfiltração marginal para cada restauração. Os resultados obtidos em cada grupo, de acordo com cada método de avaliação, são apresentados na tabela 1 e nas figuras 17 e 18. 
Tabela 1 - Valores da microinfiltração marginal $(\mathrm{mm})$ observada nos grupos de estudo, obtidos através dos três métodos de avaliação

\begin{tabular}{|c|c|c|c|c|c|c|c|c|c|c|c|c|}
\hline \multirow[b]{3}{*}{ GRUPO } & \multicolumn{12}{|c|}{ MÉTODO DE AVALIAÇÃO } \\
\hline & \multicolumn{4}{|c|}{ MICROSCÓPIO } & \multicolumn{4}{|c|}{ SIGMA ÚNICA } & \multicolumn{4}{|c|}{ SIGMA SEGM. } \\
\hline & MÉDIA & d.p. & MíN. & MÁX. & MÉDIA & d.p. & MíN. & MÁX. & MÉDIA & d.p. & MíN. & MÁX. \\
\hline $\mathbf{G I}-\mathbf{C P}$ & 1,101 & 0,379 & 0,392 & 1,920 & 0,763 & 0,371 & 0,316 & 1,717 & 1,183 & 0,944 & 0,373 & 4,877 \\
\hline GII - OS & 0,585 & 0,355 & 0,332 & 1,775 & 0,470 & 0,313 & 0,234 & 1,497 & 0,592 & 0,559 & 0,224 & 2,815 \\
\hline GIII - VT & 0,409 & 0,198 & 0,131 & 1,061 & 0,275 & 0,108 & 0,090 & 0,487 & 0,293 & 0,110 & 0,109 & 0,497 \\
\hline
\end{tabular}

d.p.: desvio padrão MíN.: valores mínimos MÁX.: valores máximos 
As figuras 17 e 18 apresentam os valores médios de microinfiltração marginal dos grupos de estudo, considerando os três métodos de avaliação.

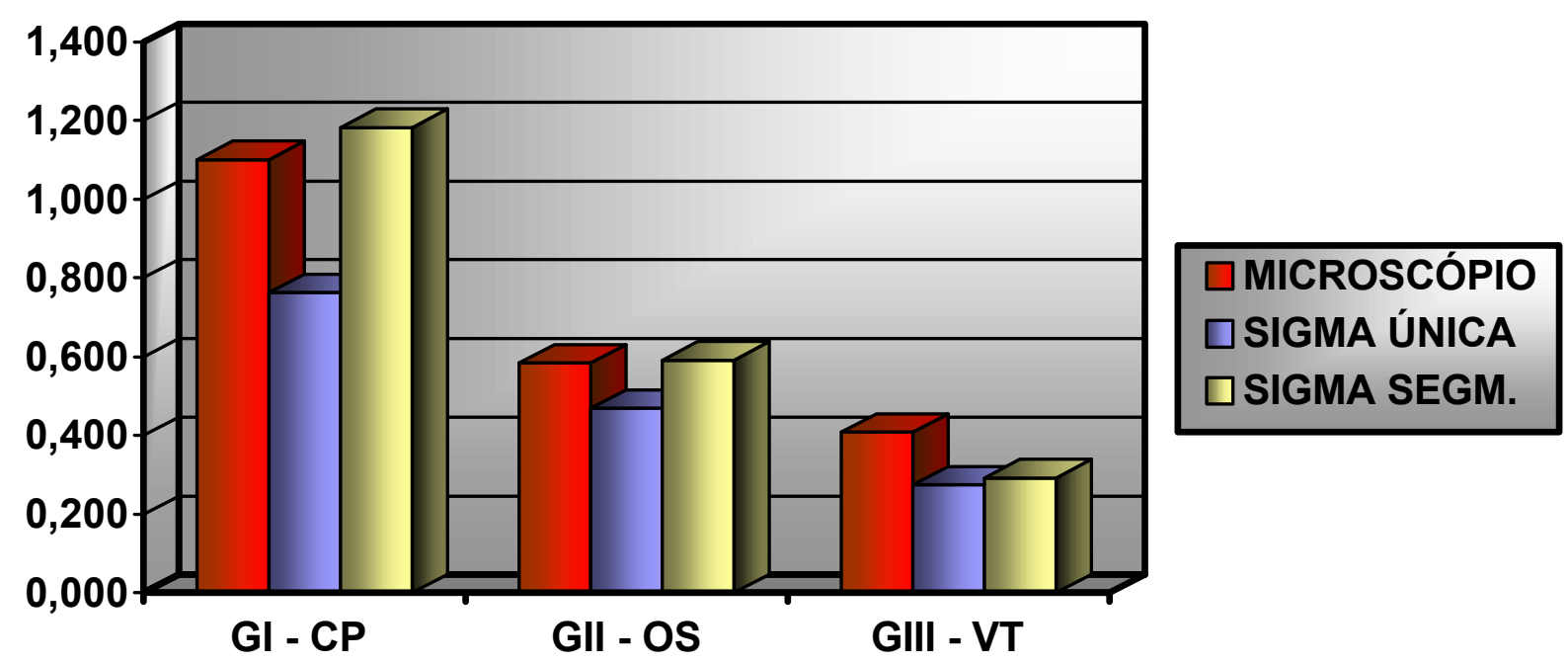

Figura 17- Valores médios da microinfiltração marginal $(\mathrm{mm})$ observada nos grupos de estudo, obtidos através dos três métodos de avaliação
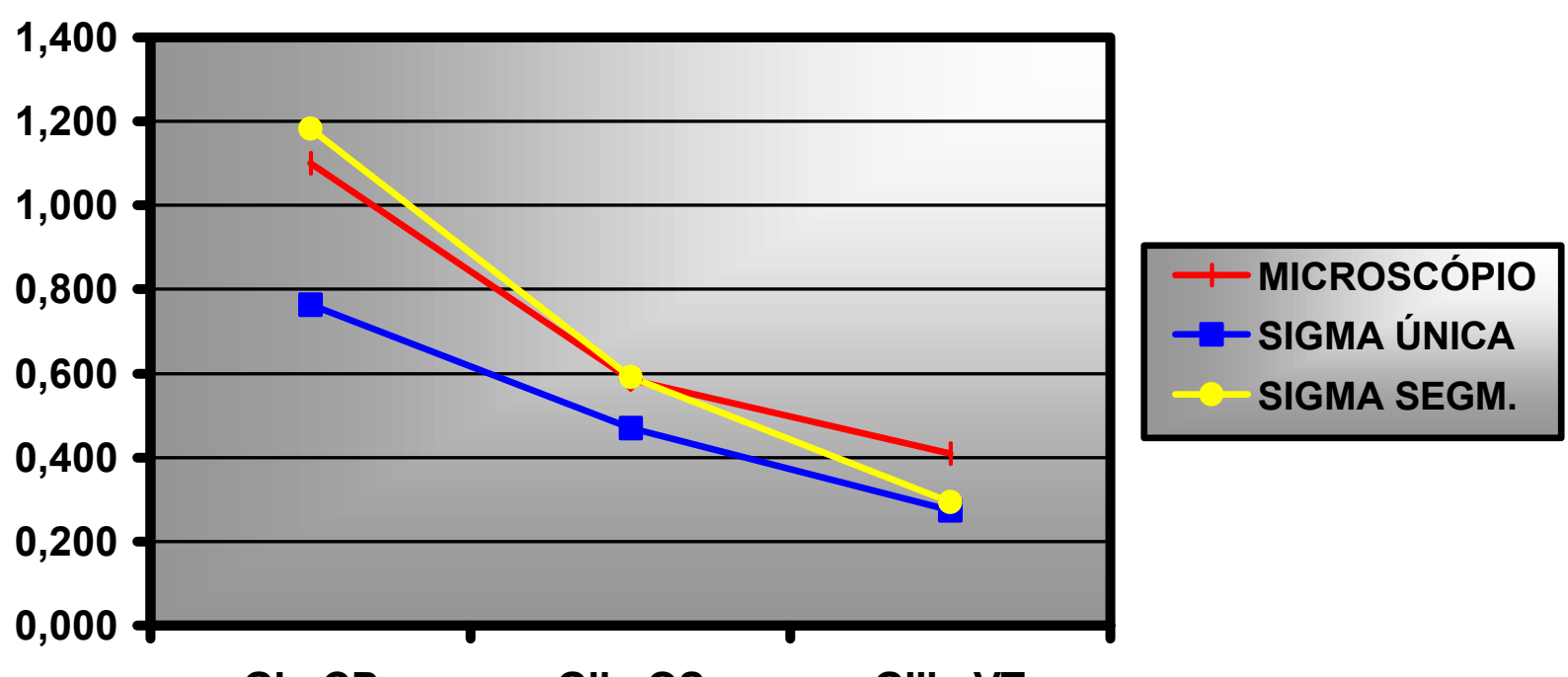

Figura 18- Valores médios da microinfiltração marginal $(\mathrm{mm})$ observada nos grupos de estudo, obtidos através dos três métodos de avaliação

Pode-se notar que os valores médio, mínimo e máximo de microinfiltração marginal obtidos através do método Sigma única (tabela 1) sempre foram menores que os observados pelo microscópio, o que não ocorreu com o Sigma segm., pois o 
mesmo apresentou uma variação maior nos resultados. No entanto, verifica-se que eles mantiveram o mesmo gradiente decrescente nos três métodos de avaliação, na seguinte ordem: GI - CP, GII - OS e GIII - VT (tabela 1 e figuras 17 e 18).

Ao se analisar o desvio padrão obtido, percebe-se que valores muito altos ocorreram ao se avaliar a microinfiltração marginal pelo método Sigma segm., embora para todos os métodos e grupos verificou-se valores consideravelmente elevados. Aquele mesmo método também foi responsável pelas maiores diferenças entre os valores mínimo e máximo da microinfiltração marginal, especialmente nos GI - CP e GII - OS. Com relação a estes dados, percebe-se que o GIII - VT destacase dos demais pelas menores diferenças encontradas nos três métodos de avaliação, tendo, assim, os menores valores máximos de microinfiltração marginal. Observa-se, portanto, que os valores médios foram dependentes tanto do material utilizado como da metodologia de avaliação.

Para verificar se haveria igualdade entre as médias de microinfiltração marginal dos diferentes grupos de estudo ou se pelo menos uma delas era diferente, aplicou-se a ANÁLISE DE VARIÂNCIA (ANOVA), considerando-se, isoladamente, os três métodos de avaliação empregados. Os dados obtidos são apresentados na tabela 2.

Tabela 2 - Parâmetros da ANOVA para os grupos de estudo nos três métodos de avaliação empregados

\begin{tabular}{|c|c|c|c|c|c|}
\hline $\begin{array}{l}\text { MÉTODO DE } \\
\text { AVALIAÇÃO }\end{array}$ & $\begin{array}{l}\text { Fonte de } \\
\text { variação }\end{array}$ & $\begin{array}{l}\text { Graus de } \\
\text { liberdade }\end{array}$ & $\begin{array}{l}\text { Quadrado } \\
\text { médio }\end{array}$ & $\mathbf{F}$ & $\mathbf{p}$ \\
\hline \multirow[t]{2}{*}{ MICROSCÓPIO } & $\begin{array}{l}\text { Efeito entre } \\
\text { tratamentos }\end{array}$ & 2 & 3,875740 & 37,59163 & $0,000000^{*}$ \\
\hline & Residual & 87 & 0,103101 & & \\
\hline \multirow[t]{2}{*}{ SIGMA ÚNICA } & $\begin{array}{l}\text { Efeito entre } \\
\text { tratamentos }\end{array}$ & 2 & 1,814420 & 22,01060 & $0,000000^{*}$ \\
\hline & Residual & 87 & 0,082434 & & \\
\hline \multirow[t]{2}{*}{ SIGMA SEGM. } & $\begin{array}{l}\text { Efeito entre } \\
\text { tratamentos }\end{array}$ & 2 & 6,148085 & 15,15139 & $0,000002^{*}$ \\
\hline & Residual & 87 & 0,405777 & & \\
\hline
\end{tabular}


Pelos valores de $\mathrm{p}$ obtidos, pode-se concluir que houve diferença estatística significante entre as médias de microinfiltração marginal dos três grupos de estudo em todos os métodos de avaliação. Para verificar entre quais grupos havia diferença significativa, foi aplicado o teste de comparações múltiplas de TUKEY (tabela 3).

Tabela 3 - Teste de TUKEY para comparações entre os grupos de estudo para cada método de avaliação empregado

\begin{tabular}{lccc}
\hline \multirow{2}{*}{ COMPARAÇÕES } & \multicolumn{3}{c}{ MÉTODOS DE AVALIAÇÃO } \\
\cline { 2 - 4 } MICROSCÓPIO & SIGMA ÚNICA & SIGMA SEGM. \\
\hline GI - CP X GII - OS & $0,000106^{*}$ & $0,000537^{*}$ & $0,001656^{*}$ \\
GI - CP X GIII - VT & $0,000106^{*}$ & $0,000106^{*}$ & $0,000107^{*}$ \\
GII - OS X GIII - VT & 0,089834 & $0,026983^{*}$ & 0,169904 \\
\hline \hline
\end{tabular}

* diferença estatisticamente significante $(p<0,05)$

Pelas tabelas 2 e 3 verifica-se que os valores da microinfiltração marginal foram maiores para o GI - CP e estatisticamente significantes aos obtidos nos Gll OS e GIII - VT com os três métodos de avaliação. Apesar do Gll - OS ter apresentado uma microinfiltração marginal maior que o GIII - VT, ela só foi considerada estatisticamente significante quando avaliada pelo método Sigma única.

Com o objetivo de verificar se haveria igualdade entre as médias de microinfiltração marginal obtidas através dos 3 métodos de avaliação ou se pelo menos uma delas era diferente, aplicou-se a Análise de Variância (ANOVA), considerando-se, isoladamente, os três grupos de estudo. Os dados obtidos são apresentados na tabela 4 . 
Tabela 4 - Parâmetros da ANOVA para os métodos de avaliação empregados nos três grupos de estudo

\begin{tabular}{cccccc}
\hline \hline \multirow{2}{*}{ GRUPO } & $\begin{array}{c}\text { Fonte de } \\
\text { variação }\end{array}$ & $\begin{array}{c}\text { Graus de } \\
\text { liberdade }\end{array}$ & $\begin{array}{c}\text { Quadrado } \\
\text { médio }\end{array}$ & $\mathbf{F}$ & $\mathbf{p}$ \\
\hline GI - CP & $\begin{array}{c}\text { Efeito entre } \\
\text { tratamentos } \\
\text { Residual }\end{array}$ & 2 & 1,483883 & 9,926951 & $0,000196^{*}$ \\
& 58 & 0,149480 & & \\
GII - OS & $\begin{array}{c}\text { Efeito entre } \\
\text { tratamentos } \\
\text { Residual }\end{array}$ & 2 & 0,142252 & 4,426481 & $0,016252^{*}$ \\
& 58 & 0,032137 & & \\
\hline & $\begin{array}{c}\text { Efeito entre } \\
\text { tratamentos } \\
\text { Residual }\end{array}$ & 2 & 0,158382 & 21,02779 & $0,000000^{*}$ \\
& R & 58 & 0,007532 & & \\
\hline \hline
\end{tabular}

${ }^{\text {* }}$ diferença estatisticamente significante $(p<0,05)$

Através dos valores de p obtidos, pode-se concluir que houve diferença estatística significante entre as médias de microinfiltração marginal dos três métodos de avaliação empregados em todos os grupos de estudo. Para verificar entre quais métodos havia diferença significativa, foi aplicado o teste de comparações múltiplas de TUKEY (tabela 5).

Tabela 5 - Teste de TUKEY para comparações entre os métodos de avaliação para grupos estudado

\begin{tabular}{llll}
\hline \hline \multirow{2}{*}{ COMPARAÇÕES } & \multicolumn{3}{c}{ GRUPOS } \\
\cline { 2 - 4 } & \multicolumn{1}{c}{ GI - CP } & GII - OS & GIII - VT \\
\hline MICROSCÓPIO X SIGMA ÚNICA & $0,003783^{*}$ & $0,040174^{*}$ & $0,000119^{*}$ \\
MICROSCÓPIO X SIGMA SEGM. & 0,689161 & 0,987681 & $0,000126^{*}$ \\
SIGMA ÚNICA X SIGMA SEGM. & $0,000371^{*}$ & $0,027750^{*}$ & 0,682427 \\
\hline \hline
\end{tabular}

${ }^{*}$ diferença estatisticamente significante $(p<0,05)$

Pelas tabelas 4 e 5 verifica-se que o microscópio apresentou valores de microinfiltração marginal estatisticamente superiores quando comparado ao método Sigma única, nos três grupos de estudo. Houve um comportamento semelhante entre os métodos Sigma segm. e Sigma única, com o primeiro apresentando maiores valores de microinfiltração marginal, porém com significância estatística 
somente para os GI - CP e Gll - OS. O contrário foi verificado entre os métodos de avaliação pelo microscópio e Sigma segm., que forneceram valores de microinfiltração marginal maiores e semelhantes entre si, com diferença estatística somente para o GIII - VT, sendo os resultados superiores para o método que empregou o microscópio.

A tabela 6 apresenta os resultados da correlação entre os três métodos de avaliação, considerando-se todas as restaurações realizadas. Observa-se que apesar das diferenças existentes na forma de análise dos métodos empregados, todos apresentaram o mesmo padrão de resultados nos diferentes grupos experimentais, evidenciado pela forte correlação positiva encontrada entre eles.

Tabela 6 - Parâmetros da Correlação de Pearson entre os métodos de avaliação empregados

\begin{tabular}{cccccc}
\hline \hline \multicolumn{1}{c}{ COMPARAÇÕES } & $\mathbf{R}$ & $\mathbf{r}^{\mathbf{2}}$ & $\mathbf{t}$ & $\mathbf{P}$ & $\mathbf{n}$ \\
\hline MICROSCÓPIO X SIGMA ÚNICA & $0,909^{*}$ & 0,827 & 20,485 & 0,000 & 90 \\
MICROSCÓPIO X SIGMA SEGM. & $0,838^{*}$ & 0,702 & 14,404 & 0,000 & 90 \\
SIGMA ÚNICA X SIGMA SEGM. & $0,915^{*}$ & 0,838 & 21,311 & 0,000 & 90 \\
\hline \hline
\end{tabular}

${ }^{*}$ forte correlação positiva $(\mathrm{R}>0,75)$

As figuras 19, 20 e 21 apresentam os aspectos característicos da microinfiltração marginal observada nos três grupos de estudo. 


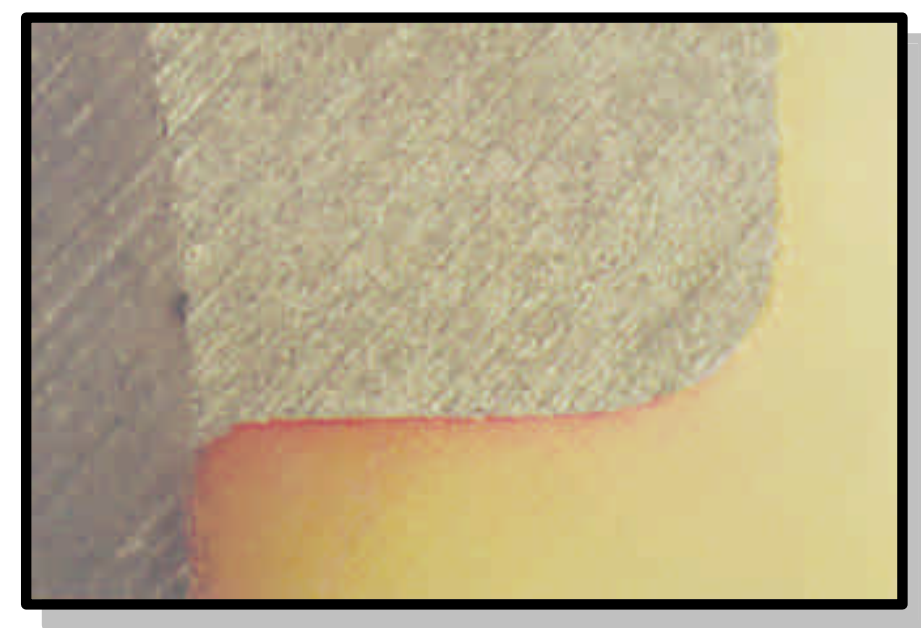

Figura 19- Aspecto característico da microinfiltração marginal no GI - CP

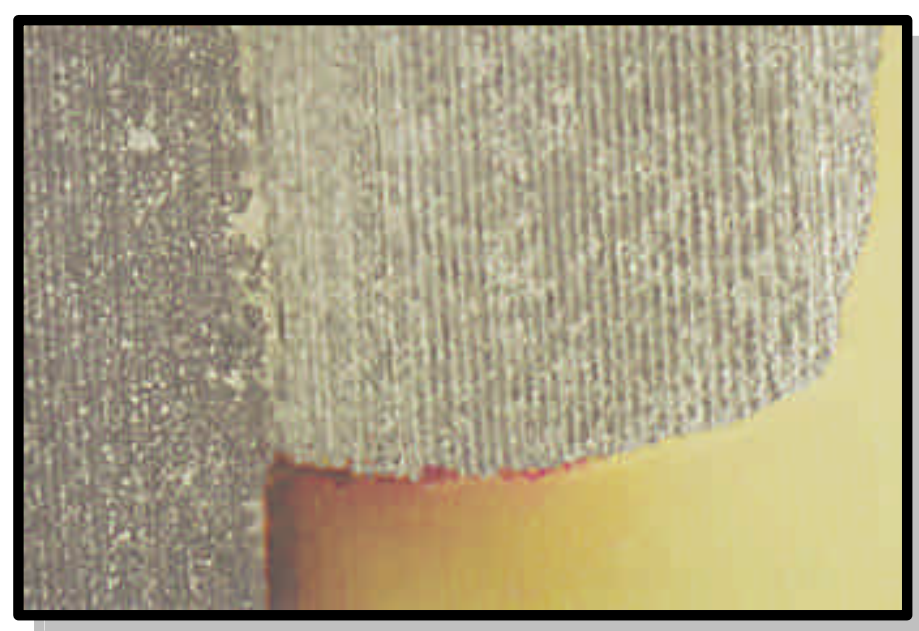

Figura 20- Aspecto característico da microinfiltração marginal no Gll - OS

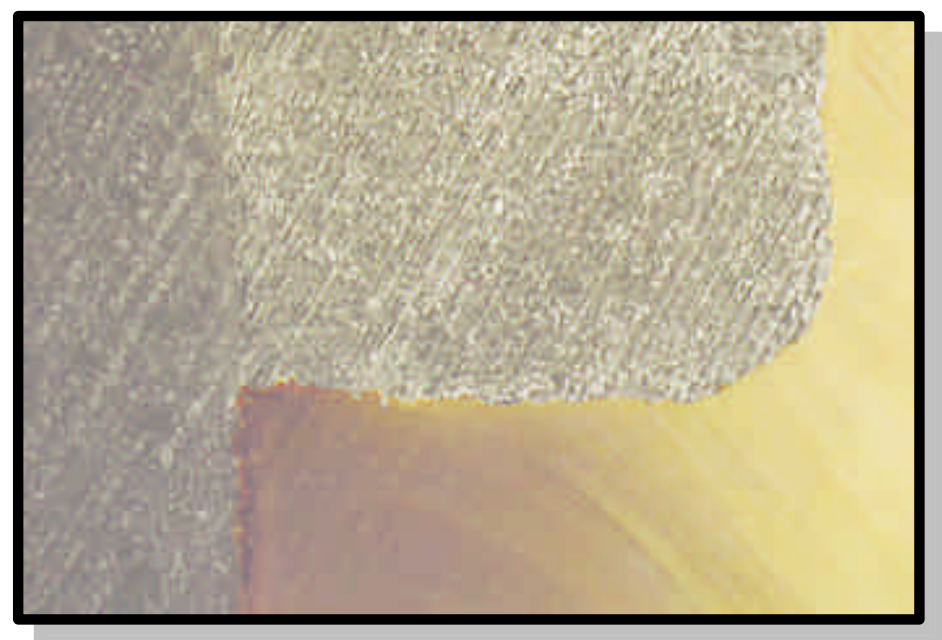

Figura 21- Aspecto característico da microinfiltração marginal no GIII - VT 
6 Discussão 


\section{DISCUSSÃO}

O amálgama dentário ainda é um material muito utilizado, principalmente por ter algumas vantagens que the são peculiares, tais como baixa sensibilidade técnica, menor necessidade de treinamento e habilidade do operador, baixo custo, autovedamento marginal, além do reduzido tempo clínico devido à fácil manipulação $2,29,30,45,55,60,64$.

Entretanto, algumas desvantagens como cor, perda de brilho, corrosão, corrente galvânica, falta de adesão à estrutura dentária, microinfiltração marginal, necessidade de uma cavidade com retenções mecânicas, bem como a preocupação referente à toxicidade do mercúrio, vêm restringindo o seu uso ou limitando o seu sucesso clínico $2,29,30,45,53,60,89,100$.

$\mathrm{Na}$ condições clínicas em que a cavidade não fornece retenção ao amálgama, o clínico é obrigado a realizar retenções adicionais como pins, pinos ou sulcos, levando a um maior desgaste de estrutura dentária sadia ${ }^{3,30,60}$. A busca de um método efetivo e seguro de promover a retenção dessas restaurações, se possível através de uma união entre o amálgama e as paredes cavitárias, poderia originar preparos cavitários mais conservadores e fortalecer a estrutura dentária remanescente $e^{3,30}$.

Devido a estas desvantagens, foram sugeridas algumas alternativas ao amálgama, tais como restaurações diretas de resina composta e "inlays" de materiais cerâmicos, cerômeros ou resina composta. No entanto, estes materiais alternativos estéticos requerem procedimentos mais complexos e um maior tempo clínico. Se a relação custo - benefício for considerada, o amálgama é ainda o material restaurador mais conveniente para dentes posteriores ${ }^{89}$.

Porém, a principal desvantagem deste material é a falta de adesão à estrutura dentária ${ }^{55,60,62,67,73,94}$, associada também à microinfiltração marginal ${ }^{60,62,67,73,94}$. Devido a isso, apesar da constante busca pela estética, muitos trabalhos ainda são realizados com o intuito de testar novos materiais que possam diminuir a microinfiltração marginal em restaurações de amálgama, como o presente estudo. 
A microinfiltração marginal é um problema antigo das restaurações de amálgama, citado já em 1952 por NELSEN; WOLCOTT; PAFFENBARGER ${ }^{70}$ e que depende da integridade da interface dente-restauração, relacionada a vários fatores, tais como propriedades físicas do material restaurador e da estrutura dentária, interação entre os diferentes materiais utilizados, além da interação entre a restauração e o meio bucal ${ }^{88}$. Esse processo consiste na penetração de fluidos bucais e bactérias na interface dente-restauração, podendo resultar em falhas marginais, cárie secundária, descoloração dentária, irritação pulpar e $\operatorname{dor}^{2}, 7,8,10,18,19,53,60,62,67,90,92,94,100,103,104,109$.

Após a condensação do amálgama na cavidade, há a formação de espaços vazios ou uma adaptação incompleta do material às paredes cavitárias pela falta de adesão à estrutura dentária, contração de cristalização, diferença entre os coeficientes de expansão térmica linear entre o material e a estrutura dentária, condensação inadequada e trituração deficiente ${ }^{62,92,104}$. Com isso, pode-se formar uma fenda marginal de $41 \mu \mathrm{m}$ de profundidade ${ }^{63}$ e 10 a $15 \mu \mathrm{m}$ de largura ${ }^{14}$ que é rapidamente preenchida por fluidos bucais e bactérias. O principal fator a ser considerado é a largura desta fenda, pois é necessário que ela tenha de 2 a $20 \mu \mathrm{m}$ para que haja penetração bacteriana, já que as bactérias patogênicas têm um tamanho de $2 \mu \mathrm{m}^{10}$. No entanto, para haver reincidência de cárie é necessário que este espaço tenha pelo menos $50 \mu \mathrm{m}$, o qual já pode ser detectado através de instrumentos odontológicos ${ }^{10}$.

Neste estudo foram utilizados pré-molares humanos, sendo os preparos estendidos $1 \mathrm{~mm}$ além da junção cemento-esmalte, em cavidades classe II distintas, já que vários trabalhos verificaram maior microinfiltração marginal em paredes localizadas em cemento/dentina do que em esmalte en, $27,33,39,53,54,60,62,67$. Os dentes utilizados foram extraídos por indicação ortodôntica e armazenados em solução de timol a $0,1 \%$, a uma temperatura de aproximadamente $4^{\circ} \mathrm{C}$. Esta é capaz de prevenir o crescimento bacteriano e o possível contágio durante a manipulação dos dentes, além de não alterar os tecidos dentários ${ }^{46}$. 0 meio de armazenagem dos dentes podem interferir nos resultados dos experimentos realizados in vitro. Existem várias soluções, entre as quais podem ser citadas a formalina a $10 \%$, cloramina a $1 \%$, etanol a $70 \%$, solução fisiológica, timol a $0,1 \%$ e azida sódica. Dentre estas, a única que parece interferir nos resultados é a formalina ${ }^{46}$, causando uma diminuição da 
microinfiltração marginal, provavelmente devido a uma ligação cruzada entre as proteínas das fibras colágenas promovida pela ação fixadora do formaldeído ${ }^{92,104}$.

Apesar da grande maioria dos estudos utilizarem cavidades classe $\mathrm{V}^{4,5,6,8,15,16,17,27,29,31,38,39,50,53,59,61,62,67,68,72,73,82,90,92,94,97,98,99}$, cavidades classe II são mais freqüentes na clínica odontopediátrica, pois os dentes decíduos possuem uma coroa curta no sentido cérvico-oclusal e uma superfície de contato proximal plana e deslocada para cervical, o que leva à progressão mais rápida da lesão cariosa nos sentidos vestíbulo-lingual e cervical. Este tipo de cavidade também foi empregada em outros estudos ${ }^{7,19,37,48,60,75,79,100}$. Idealmente, deveriam ser utilizados dentes decíduos para a realização deste experimento, como realizado por ROYSE; OTT; MATHIEU ${ }^{90}$, porém a coleta de um número suficiente é extremamente difícil. Além disso, os pré-molares também podem necessitar de um tratamento realizado pelo odontopediatra, o que justifica seu uso neste estudo.

A forma da partícula e o tipo de liga também podem influenciar na severidade da microinfiltração marginal. No presente trabalho foi empregado o DISPERSALLOY, que é uma liga de fase dispersa, composta por partículas esféricas de prata-cobre e limalha de prata-estanho, com alto conteúdo de cobre e muito empregada em estudos de amálgama, devido às suas excelentes propriedades físicas. Alguns autores têm demonstrado que a liga esférica possui maior tendência à microinfiltração marginal que a mista ${ }^{48,57,62,90,92}$, provavelmente devido à melhor adaptação desta última às paredes cavitárias, pois, com ela, é possível aplicar uma força de condensação maior ${ }^{74,92}$. As restaurações realizadas com ligas esféricas formam produtos de corrosão mais lentamente por serem compostas por uma fase simples ${ }^{62}$ e possuem uma superfície interfacial mais rugosa, podendo originar fendas através das quais a microinfiltração marginal pode ocorrer $^{57}$. Por outro lado, alguns estudos não encontraram diferença estatisticamente significante entre ligas esféricas e mistas ${ }^{53,100,104}$. Para ambas as ligas, o aumento da plasticidade do material, da força de condensação, com forças dirigidas contra as paredes cavitárias e a brunidura pré-escultura diminuem a microinfiltração marginal ${ }^{57}$.

Quando exposto ao meio bucal, as restaurações novas são sujeitas à corrosão, liberando produtos na fenda marginal. Esta reação ocorre principalmente entre o oxigênio e o estanho do amálgama, formando compostos como óxido de estanho e cloreto de estanho, além de pequenas quantidades de fósforo e cálcio, 
que são depositados na interface dente-restauração. Este fato acontece principalmente com a fase gama 2, diminuindo a microinfiltração marginal com 0 envelhecimento da restauração ${ }^{19,27,41,53,62,67,94,100,104}$. As ligas com alto conteúdo de cobre possuem melhores propriedades físicas que as convencionais devido à baixa corrosão, maior resistência à compressão e menor "creep" 10,41. A corrosão do material existe, porém geralmente é limitada à superfície. Isso ocorre porque nestas ligas há uma quantidade substancial de cobre, o qual tem grande afinidade ao estanho, formando a fase eta. Com isso, a formação de fase gama 2 é parcial ou quase que totalmente suprimida ${ }^{41,62,94}$. Como conseqüência, a corrosão destas ligas se processa mais lentamente do que nas ligas convencionais, havendo menor formação de produtos que vedam a interface dente-restauração ${ }^{62,94}$. As ligas com alto conteúdo de cobre demoram o dobro de tempo ${ }^{20}$ ou até mesmo dois anos ou mais $^{62}$ para alcançarem o mesmo padrão de vedamento marginal que as ligas convencionais, que se inicia aproximadamente aos 6 meses. A degradação da "smear layer", provocada pela penetração de fluidos bucais ou pela ação de bactérias, associada à menor corrosão das ligas com alto conteúdo de cobre, pode gerar fendas de 1 a $2 \mu \mathrm{m}$ em restaurações sem proteção, o que aumenta a microinfiltração marginal até 6 meses após a sua realização ${ }^{2}$. Porém, MOORE; WILLIAN; KAPLAN ${ }^{66}$ observaram uma diminuição da microinfiltração marginal em restaurações com esse tipo de liga associadas ao verniz cavitário após um tempo de armazenagem de um ano, provavelmente devido à formação de produtos de corrosão na interface dente-restauração.

Vários materiais e técnicas têm sido preconizados para minimizar a microinfiltração marginal. Justamente por haver esta grande diversidade, buscou-se, neste trabalho, avaliar um verniz cavitário, um adesivo dentinário e um CIV. Tradicionalmente, os vernizes cavitários têm sido aplicados, reduzindo significativamente a microinfiltração marginal em restaurações de amálgama recentes em comparação àquelas realizadas sem material intermediário $^{2,4,5,7,14,16,17,18,19,22,38,40,47,50,53,59,67,68,90,92,94,97,98,102,103}$. Este fato ocorre porque o verniz cavitário preenche os espaços entre o amálgama e as paredes cavitárias.

Entretanto, alguns estudos concluíram que o verniz cavitário não diminui os valores de microinfiltração marginal| $28,29,37,48,53,60,62,72,73,92,99$, o que pode ocorrer pela existência de fendas marginais, as quais podem ser observadas tanto em 
restaurações sem material intermediário como naquelas forradas com verniz cavitário, inclusive com a presença de túbulos dentinários permanecendo abertos ${ }^{104}$. Mesmo numa avaliação inicial (2 semanas), o verniz cavitário permite uma microinfiltração marginal considerável, principalmente na parede cervical ${ }^{14}$.

Apesar de não ser um objetivo deste experimento, foi possível verificar que os espécimes restaurados com verniz cavitário apresentaram, com grande freqüência, penetração do corante nos túbulos dentinários (figura 19). Isto ocorre porque o verniz cavitário é um material hidrofóbico e poroso que não se une ao amálgama e à estrutura dentária ${ }^{7,18,19,76,103,109}$, produzindo apenas um vedamento mecânico e não uma união molecular ${ }^{73}$, com a ocorrência de algum grau de microinfiltração marginal nas interfaces entre 0 verniz e o dente ou restauração. Através das tabelas 1 e 3 pode-se observar que o verniz cavitário apresentou os maiores valores médios de penetração do corante, com diferenças estatisticamente significantes em comparação aos outros grupos, independentemente dos métodos de avaliação empregados.

Com o passar do tempo, o verniz cavitário sofre uma dissolução no meio bucal, 0 que pode provocar uma deficiência no vedamento marginal ${ }^{7,14,15,23,40,41,53,59,62,66,67,73,76,82,83,92,102}$, causando um aumento na microinfiltração marginal após um período de aproximadamente 6 meses ${ }^{66}$. Além da dissolução, também pode haver irregularidades e porosidades na camada de verniz $^{73,94}$ ou a dissolução da "smear layer" ${ }^{2}$.

Por isso, embora ele seja capaz de promover um bom vedamento inicial nas restaurações de amálgama, não se pode considerar que seja um material de vedamento permanente da interface dente-restauração ${ }^{7,23,53,62,66,67,73,76}$. Talvez este seja um fator positivo, pois o verniz dissolvido pode ser substituído gradualmente pelos produtos da corrosão da fase gama 2 do amálgama, diminuindo a microinfiltração marginal ${ }^{14,15,23,41,62,66}$. Porém, a corrosão das ligas de alto conteúdo de cobre pode não ser suficiente para vedar a interface se a fenda marginal existente pela dissolução do verniz for muito ampla ${ }^{41}$. As características de solubilidade do verniz, além da menor corrosão das ligas com alto conteúdo de cobre, sugerem que podem ocorrer problemas com o tratamento restaurador devido à microinfiltração marginal.

Este material foi aplicado, nesta pesquisa, com auxílio de um aplicador descartável do tipo "microbrush", em duas camadas, sendo que cada uma foi seca 
por jatos de ar por 30 segundos, como recomenda o fabricante. A aplicação de uma simples camada fornece uma espessura de $2 \mu \mathrm{m}$, que favorece a evaporação do solvente, promovendo uma secagem rápida ${ }^{56}$. Porém, esta fina camada pode sofrer rupturas microscópicas durante a condensação do amálgama, causando um vedamento marginal insatisfatório ${ }^{17}$. Com a aplicação de duas camadas não é mais possível a visualização dos túbulos dentinários, fibras colágenas e outras irregularidades dentinárias, além de constituir uma espessura suficiente para bloquear o acesso aos túbulos dentinários e à polpa, mantendo uma textura superficial que permite a retenção mecânica do amálgama à cavidade ${ }^{56}$.

Existem diferentes métodos de aplicação do verniz cavitário, como pincéis de pêlo ${ }^{16,19,40,71}$, aplicadores de algodão ou bolinhas de algodão ${ }^{17,38,75,97,100}$, alças metálicas $^{56}$ e bolinhas de espuma ${ }^{15}$. A secagem por 30 segundos com jatos de ar também foi realizada por outros estudos ${ }^{15,75,100}$, porém há uma grande variação desse procedimento nos diversos trabalhos presentes na literatura, já que alguns apenas dirigem um "leve jato de ar" 19,40,50 enquanto outros esperam sua secagem espontânea por 5 minutos após cada camada ${ }^{71}$.

Como as restaurações de amálgama apresentam uma fenda marginal, é interessante ter um material sob ele que possa contribuir com a prevenção da recidiva de cárie e possa promover a adesão da restauração ao dente, o que pode ser conseguido com os $\mathrm{CIV}^{3,59}$. Esta ação provavelmente se deve a um conjunto de fatores, tais como liberação de flúor $^{69}$, baixo $\mathrm{pH}$ inicial ${ }^{69}$, união química com a estrutura dentária ${ }^{69}$, liberação de cátions metálicos ${ }^{48,59}$, coeficiente de expansão térmica linear semelhante ao da estrutura dentária ${ }^{1,44,69,74,77}$, além de apresentar satisfatória resistência à compressão e radiopacidade ${ }^{44,69}$, sendo um material hidrofílico, o que o torna capaz de se aderir à estrutura dentária mesmo com a presença de umidade dentinária ${ }^{84}$. No caso de CIV modificados por resina, soma-se a vantagem do controle do tempo de trabalho pela incorporação de um componente resinoso ativado pela luz ${ }^{1,42,44,69,74,77}$, menor sensibilidade quanto à sorpção inicial de água ${ }^{42,44,74}$, menor solubilidade e maior resistência de união à estrutura dentária ${ }^{69}$.

Tanto os CIV modificados por resina como os convencionais possuem boas propriedades físicas, sendo que o convencional apresenta maior módulo de elasticidade $^{48,77}$, o que suportaria melhor uma restauração de amálgama ${ }^{48}$. Aquele material possui um módulo de elasticidade bem menor que os CIV convencionais e a 
própria dentina, o que parece não interferir na resistência à fratura de uma restauração de amálgama 1 hora ou 7 dias após sua realização ${ }^{77}$.

O CIV utilizado neste estudo foi o VITREMER, que é um CIV modificado por resina de grande aplicabilidade clínica em Odontopediatria, sendo utilizado para restaurações de dentes anteriores e posteriores decíduos e permanentes, como núcleo de preenchimento e selamento de fossas e fissuras. A proporção utilizada foi a mesma preconizada para selamento, ou seja, $1 / 4$ do pó para uma gota do líquido ${ }^{49}$. Esta modificação foi realizada para a obtenção de uma mistura mais fluida que pudesse ser aplicada nas paredes cavitárias com maior facilidade e homogeneidade, apesar da possibilidade deste procedimento influenciar nas propriedades físicas do material. Poucos autores utilizaram este mesmo CIV para realizar restaurações de amálgama $^{74,82}$. Além disso, nestes estudos, o material foi proporcionado de acordo com as instruções do fabricante, ou seja, em uma proporção de 1:1.

No presente trabalho, o amálgama foi condensado sobre o CIV ainda em fase plástica, o que resulta em uma fina camada de CIV entre o dente e o amálgama, como realizado em outros trabalhos que avaliaram a microinfiltração marginal $^{79,82,100,102,108}$.

O CIV foi o material que apresentou o melhor desempenho neste estudo, corroborando com resultados de outros autores, que observaram que a aplicação de CIV diminuiu a microinfiltração marginal em restaurações de amálgama quando comparado ao verniz cavitário ${ }^{79,82,102}$ ou sistema adesivo ${ }^{82}$. Quando o CIV foi aplicado, observou-se uma menor penetração do corante nos túbulos dentinários (figura 21) em comparação ao grupo do verniz cavitário, indo ao encontro de resultados obtidos em outros trabalhos ${ }^{102,108}$. Este padrão pode ter ocorrido por haver um melhor selamento dentinário com o CIV e pela penetração do corante na massa deste material, o que poderia minimizar a infiltração pelos túbulos dentinários $^{108}$.

No entanto, alguns estudos concluíram que os resultados de microinfiltração marginal em restaurações de amálgama associadas aos CIV são semelhantes $^{82,102}$ ou piores ${ }^{79}$ que os obtidos com sistemas adesivos e até mesmo semelhantes ou piores que restaurações sem qualquer proteção ou com verniz cavitário ${ }^{100,108}$.

Apesar dos resultados positivos obtidos com o CIV em relação aos outros grupos (tabela 1 e figuras 17 e 18), eles não foram estatisticamente superiores ao 
GII - OS em todos os métodos de avaliação estudados, exceto com o método Sigma única (tabela 3). Esse achado corrobora os resultados de autores acima citados, que obtiveram resultados semelhantes entre o CIV e o sistema adesivo. Além disso, foi possível observar uma maior uniformidade dos resultados obtidos com o CIV em comparação aos outros materiais, sobretudo nos métodos que utilizaram imagens digitalizadas. As características inerentes dos materiais e suas formas de aplicação resultaram em vedamentos marginais com diferentes graus de efetividade para os três grupos de estudo, o que se verifica pela diferença nos valores médios, mínimos e máximos obtidos (tabela 1). A discrepância nos valores da microinfiltração marginal foi evidente sobretudo para os GI - CP e Gll - OS, o que se observa pelo elevado desvio padrão neles encontrado, principalmente para os dois métodos de avaliação digitalizados.

Os resultados satisfatórios obtidos com este material podem ser conseqüência de algumas de suas propriedades já citadas anteriormente, como adesão à estrutura dentária ${ }^{1,42,44,69,74,77}$ e tolerância a certa umidade ${ }^{84}$.

No caso do VITREMER é indicada a aplicação de um "primer" que melhora a capacidade de molhamento da dentina ${ }^{86}$, o qual é composto por $46 \%$ de HEMA, $39 \%$ de álcool etílico e $13 \%$ de copolímero de ácido carboxílico ${ }^{93}$, além de ácido maleico ${ }^{42}$, constituindo-se em um "primer" autocondicionante fotopolimerizável ${ }^{42}$. Após sua aplicação há a remoção de grande parte da "smear layer", mantendo a integridade da "smear plug" ${ }^{42}$, o que provavelmente contribuiu para o eficiente vedamento dos canalículos dentinários neste grupo. Este sistema proporciona uma ação simultânea do condicionamento ácido e da penetração do "primer" ${ }^{65}$, garantindo uma união micromecânica do material à estrutura dentária.

O coeficiente de expansão térmica linear semelhante ao da estrutura dentária poderia ser uma vantagem se um CIV convencional fosse usado ${ }^{1,44,74,77}$. No entanto, os CIV modificados por resina possuem valores superiores em relação a esta propriedade ${ }^{69}$.

Além de melhorar a performance da restauração em relação à microinfiltração marginal, a aplicação do CIV seguida de condensação do amálgama com o material ainda em fase plástica aumenta a resistência de união do amálgama à estrutura dentária ${ }^{3}$ ou a uma base de CIV previamente inserida ${ }^{1,74}$, melhorando a retenção da restauração ${ }^{74}$. A união entre o CIV e o amálgama ocorre devido ao embricamento mecânico entre os dois materiais ${ }^{1,3,102} \mathrm{e}$, em parte, à afinidade dos 
numerosos ânions dos grupamentos carboxílicos do ácido poliacrílico aos cátions metálicos da liga ${ }^{74}$.

Pode haver uma incorporação do material adesivo ainda em fase plástica na massa do amálgama durante a sua condensação $3,24,30,47,55,58,64,96$, formando ilhas ou infiltrações que podem causar uma queda na resistência à compressão ${ }^{30}$ ou à tração diametral do material ${ }^{64}$. Este problema pode ter ocorrido no GIII - VT, já que o CIV não foi fotopolimerizado antes da condensação do amálgama. Isso pode ser explicado pelo fato do material em fase plástica aderir-se ao condensador e incorporar-se na massa do amálgama, além de dificultar a eliminação do excesso de mercúrio que aflora, pois esta camada vai se aderindo ao condensador e retornando à restauração ${ }^{30}$. Neste trabalho, o condensador foi limpo com uma gaze, como preconizado por MAHLER et al. ${ }^{58}$, sempre que um excesso de material se acumulava em sua ponta ativa, com o intuito de evitar ou reduzir este problema. Porém, SAIKU; GERMAIN JUNIOR; MEIERS ${ }^{92}$ não observaram esta mistura entre os materiais.

Para minimizar este problema, é importante aplicar apenas uma fina camada do material adesivo nas paredes cavitárias, tomando-se o cuidado para não formar áreas de acúmulo do material ${ }^{21,64}$, que ocorrem principalmente nos ângulos do preparo, podendo enfraquecer a restauração em áreas de maior estresse, como istmo, vertentes de cúspides e margens ${ }^{58}$.

A obtenção de uma camada fina é mais difícil com a utilização de materiais autopolimerizáveis, pois a reação de presa se inicia desde a mistura, o que pode resultar em áreas de maior espessura do material devido ao menor tempo de trabalho $^{21}$. O VITREMER também apresenta a reação química ácido-base que caracteriza os CIV. Por essa razão, a fluidificação do material só foi realizada imediatamente antes do início da condensação do amálgama. Com esse cuidado, procurou-se minimizar as conseqüências desfavoráveis de uma fluidez decrescente com o tempo, pois, quanto mais viscoso for o material aplicado, maior a dificuldade do mesmo fluir pelas paredes cavitárias, o que poderia aumentar a sua propensão de ser incorporado na massa de amálgama ${ }^{64}$.

O terceiro material utilizado neste estudo foi o sistema adesivo monocomponente fotopolimerizável OPTIBOND SOLO, que pode ser denominado de "self-priming", segundo MIYAZAKI; SATO; ONOSE ${ }^{65}$, pois requer um condicionamento ácido prévio. Ele consiste de uma solução hidrofílica que penetra 
na estrutura dentária atacada, propiciando a formação de "tags" de resina ${ }^{65}$. Este material possui aproximadamente $25 \%$ de carga inorgânica, o que poderia melhorar a sua performance na resistência aos esforços mastigatórios. Assim, ele funcionaria como uma camada elástica capaz de absorver os estresses funcionais concentrados na interface adesiva, preservando a união entre o substrato dentário e o material restaurador ${ }^{26}$.

O interesse pela utilização de materiais resinosos sob restaurações de amálgama surgiu principalmente a partir do desenvolvimento de sistemas quimicamente ativados para a retenção de próteses, com o objetivo principal de se obter uma restauração adesiva ${ }^{11}$. Um dos primeiros trabalhos realizados com esta intenção foi conduzido por VARGA; MATSUMURA; MASUHARA ${ }^{105}$, em 1986, que utilizaram os adesivos PANAVIA Ex e 4-META / MMA-TBB. Através da utilização destes materiais sob restaurações de amálgama é possível diminuir a microinfiltração marginal, reduzir a recidiva de cárie e unir a restauração à estrutura dentária, melhorando sua retenção e reforçando o dente contra fraturas, além de diminuir a sensibilidade pós-operatória ${ }^{21,23,45,47,74,94,102,104}$.

Existem basicamente duas técnicas para a realização de restaurações de amálgama associadas a sistemas adesivos, semelhante ao que foi descrito para os CIV. Na primeira, o amálgama é condensado sobre o material ainda em estado viscoso, ocorrendo uma mistura entre eles, a qual promoverá uma união micromecânica que pode melhorar a retenção da restauração $2,3,20,22,24,28,29,30,31,36,53,58,62,64,66,67,74,75,79,82,92$. A segunda técnica consiste na condensação do amálgama sobre o adesivo já polimerizado, com a intenção de apenas melhorar o vedamento marginal ${ }^{1,7,18,19,21,22,35,36,39,44,53,54,67,87,90,109}$, como o que foi realizado neste experimento.

Os resultados do presente estudo confirmam os achados de outros trabalhos ${ }^{7,19,21,22,39,53,67,90}$ que utilizaram adesivos já polimerizados associados a restaurações de amálgama, pois uma marcante redução da microinfiltração marginal foi observada em comparação ao grupo do verniz cavitário (tabela 1 e figuras 17 e 18). Porém, DUTTON et al. $^{38}$ não encontraram diferença estatisticamente significante entre estes dois materiais.

A microinfiltração marginal observada nas restauração de amálgama com adesivo ocorre geralmente entre o adesivo e o amálgama e não entre o adesivo e a estrutura dentária ${ }^{19}$. Na interface dente-adesivo há a formação de uma camada 
híbrida com o colágeno da dentina, o que promove um selamento deste tecido, diminuindo a microinfiltração através dos túbulos dentinários quando comparado ao aspecto observado com o verniz cavitário ${ }^{19,20,55,58,74,92,96,100,104}$. Neste trabalho, uma marcante redução da penetração do corante ao longo dos túbulos dentinários também foi observada no Gll - OS (figura 20).

Também é importante salientar que o substrato dentário é variável, já que é constituído por esmalte e dentina. A própria dentina apresenta uma grande variação, dependendo da idade do dente e de sua profundidade ${ }^{25,78}$. Com o tempo, há uma deposição de dentina ao redor dos túbulos dentinários, tornando-os menos calibrosos, o que ocorre pela esclerose fisiológica e como resposta a estímulos externos, tais como cárie, atrição, abrasão e erosão ${ }^{25,78}$. A adesão à dentina esclerosada pode ser prejudicada pela menor receptividade aos adesivos dentinários, levando à formação de uma camada híbrida mais fina, principalmente em casos de lesões de erosão ou abrasão. O mesmo ocorre com a dentina profunda ou a dentina de dentes jovens, devido ao maior calibre dos túbulos dentinários, o que aumenta a contaminação da superfície preparada com fluído dentinário ${ }^{25,78}$. Como em Odontopediatria 0 tratamento dos dentes permanentes estaria praticamente restrito a dentes jovens, procurou-se selecionar pré-molares de adolescentes com indicação de extração ortodôntica.

$\mathrm{Na}$ cavidade bucal, os dentes sofrem constantes processos de fadiga térmica, mecânica ou química com o tempo. Uma falha na interface dente-adesivo, pode originar uma série de problemas: sensibilidade pós-operatória devido à falta de selamento dos túbulos dentinários, perda de resistência do dente preparado e penetração de bactérias na interface dente-adesivo ${ }^{58}$. Tem sido observado um aumento da microinfiltração marginal em restaurações de amálgama associadas a sistemas adesivos resinosos após um período de 30 dias $^{92}$ ou de um ano ${ }^{66}$, provavelmente devido a uma ruptura da ligação adesiva por degradação hidrolítica do adesivo ${ }^{66,92}$ ou por deterioração do colágeno exposto que se localiza entre a camada híbrida e a dentina inalterada ${ }^{92}$. Este problema pode ser provocado por uma desmineralização excessiva promovida pelo condicionamento ácido, associada a uma incompleta difusão do adesivo, deixando uma camada de dentina sem proteção do adesivo ${ }^{92,100}$. Um outro problema que pode ocorrer é o colapso das fibras colágenas expostas por secagem excessiva da superfície, o que impediria a penetração do adesivo ${ }^{100}$. O material empregado neste trabalho emprega 0 
condicionamento ácido por 15 segundos, seguido de uma secagem por aproximadamente 2 segundos e aplicação cuidadosa do adesivo para permitir que o mesmo penetre em toda extensão da dentina e/ou esmalte atacados. Entretanto, há trabalhos que não encontraram diferença significativa na microinfiltração marginal em restaurações de amálgama com adesivos observada após 6 meses $^{2,82,94}$ ou 1 ano ${ }^{62}$, em comparação a tempos inferiores.

No sistema adesivo utilizado neste trabalho, o fabricante recomenda que apenas uma fina camada de adesivo seja aplicada, esfregando-o levemente por 15 segundos, o que eliminaria a necessidade de aplicação de jatos de ar. Esta é uma recomendação pertinente, já que a aplicação de jatos de ar deve ser evitada para que o agente adesivo não se espalhe para áreas fora do limite cavitário, dificultando sua remoção posterior e facilitando o acúmulo de placa ${ }^{26}$. Além disso, o jato de ar pode determinar áreas com ausência total do adesivo e pode dificultar a polimerização pela inclusão de ar nesta camada ${ }^{26}$.

Uma vantagem da associação de materiais adesivos ao amálgama é a inibição de cárie secundária. No entanto, os estudos in vivo ${ }^{12,76,91}$ não têm demonstrado diferença entre restaurações com ou sem adesivo, talvez por não haver pesquisas utilizando indivíduos com alta atividade de cárie e com número significativo de restaurações ${ }^{96}$. É possível controlar a instalação de lesões de cárie secundária numa restauração de amálgama diminuindo a microinfiltração marginal pelo emprego de materiais adesivos ou aplicando bases de $\mathrm{CIV}^{81}$, aliado a uma higiene bucal satisfatória. Os CIV diminuem a taxa de desmineralização ao redor das restaurações de amálgama quando os espécimes são submetidos a uma solução desmineralizadora, o que provavelmente ocorre pela liberação de flúor do material ${ }^{67}$.

Além da recorrência de cárie, a sensibilidade dentária pós-operatória é um problema que acomete muitos indivíduos, especialmente após um procedimento odontológico, ou em decorrência de microinfiltração marginal ${ }^{44}$. Para eliminá-la ou reduzi-la, bases e materiais protetores têm sido usados. Os sistemas restauradores empregados neste estudo trataram a superfície dentária de diferentes formas e isso, em procedimentos in vivo, pode influenciar na sensibilidade pós-operatória dos pacientes. Quando uma restauração de amálgama é realizada sem proteção ou com a aplicação de verniz cavitário, a "smear layer" é mantida intacta, ocluindo os túbulos dentinários e reduzindo a sensibilidade pós-operatória temporariamente ${ }^{44}$. Com a realização do condicionamento ácido, há uma exposição dos túbulos dentinários 
pela remoção da "smear layer", assim como uma desmineralização parcial da dentina, que será preenchida pelo "primer" do sistema adesivo, formando a camada híbrida, que funciona como uma base isolante da restauração ${ }^{44}$.

Para a condensação do amálgama, os dentes foram montados em um bloco de gesso com cera para simular a condição encontrada in vivo, com pontos de contato proximais e utilização de matrizes e cunhas para melhor adaptação do material na parede cervical, como realizado por outros autores ${ }^{75,79}$. A inserção do material deve ser em pequenos incrementos e sua condensação realizada com um instrumento compatível com a cavidade, usando inicialmente força pesada até que toda a cavidade seja preenchida com sobra de material, para que excesso de mercúrio não permaneça na superfície da restauração ${ }^{14}$.

A realização da brunidura pré-escultura e pós-escultura contribuem com a redução da microinfiltração marginal ${ }^{14,17,40,57}$. Neste estudo foi realizada uma brunidura pré-escultura com um brunidor de tamanho maior que a cavidade e um alisamento pós-escultura com bolinha de algodão, apenas para promover um refinamento superficial, evitando o risco de provocar um afloramento de mercúrio para a superfície.

Após a realização das restaurações, os espécimes foram armazenados em água por 24 horas, em uma temperatura de $37^{\circ} \mathrm{C}$, para que se concretizasse a reação dos materiais. Esta espera não influencia nos resultados de microinfiltração marginal ${ }^{32}$.

A termociclagem, neste estudo, foi realizada em água nas temperaturas de $5^{\circ} \mathrm{C}$ e $55^{\circ} \mathrm{C}$, com banhos de 15 segundos, num total de 500 ciclos. Procedimento idêntico foi realizado por vários autores ${ }^{75,79,82}$, que também estudaram a microinfiltração marginal em restaurações de amálgama. No entanto, há uma grande variação nas temperaturas, número de ciclos e tempo de imersão nos banhos, reflexo da falta de padronização dos estudos de microinfiltração marginal e da busca constante em simular as condições encontradas na cavidade bucal nos estudos in vitro, o que dificulta a comparação dos resultados com os obtidos por outros trabalhos.

Apesar disso, a termociclagem é ainda um procedimento válido, já que o coeficiente de expansão térmica linear do material é um importante fator na ocorrência de microinfiltração marginal ${ }^{85,88}$. Este fenômeno consiste na mudança do comprimento por unidade de comprimento de um determinado material, quando sua 
temperatura é aumentada ou diminuída em um grau ${ }^{80}$. A estrutura dentária possui um determinado coeficiente de expansão térmica linear (esmalte: $11,4 \times 10^{-6} .{ }^{\circ} \mathrm{C}^{-1}$; dentina: $8,3 \times 10^{-6} \cdot{ }^{\circ} \mathrm{C}^{-1}$ ), assim como cada material restaurador ${ }^{69}$. Se o valor entre eles for similar, a microinfiltração marginal será menor. Porém, os materiais disponíveis possuem coeficientes bastante diferentes (amálgama: $25 \times 10^{-6} \cdot{ }^{\circ} \mathrm{C}^{-1}$; resina composta híbrida: $35 \times 10^{-6} .{ }^{\circ} \mathrm{C}^{-1}$; CIV modificado por resina: $31,5 \times$ $\left.10^{-6} \cdot{ }^{\circ} \mathrm{C}^{-1}\right)$. Seja qual for 0 material, o coeficiente de expansão térmica linear contribui em aproximadamente $90 \%$ das trocas de fluido durante a contração e expansão com a variação de temperatura ${ }^{10}$.

Além de possuir um coeficiente de expansão térmica linear maior que o da estrutura dentária, o amálgama é um pobre isolante térmico, com uma condutividade de aproximadamente 20 vezes maior que o da estrutura dentária. Por isso, observa-se um aumento na microinfiltração marginal quando a termociclagem é realizada $^{33,88}$.

A termociclagem é um procedimento in vitro que tenta simular as temperaturas extremas, tanto as quentes quanto as frias, que ocorrem na cavidade bucal $^{8,33,43,88,106}$, numa tentativa de provocar o envelhecimento das restaurações ${ }^{8,65}$. Com isso, é possível relacionar os coeficientes de expansão térmica linear do dente e do material restaurador, já que uma diferença entre eles pode causar uma percolação e subseqüente microinfiltração marginal| ${ }^{88,106}$. A termociclagem é necessária porque submete os materiais a situações que simulam a condição clínica, provocando um estresse na interface dente-restauração, pelas diferentes temperaturas empregadas. A temperatura máxima pode variar de $40^{\circ} \mathrm{C}$ a $100^{\circ} \mathrm{C}$, com uma mediana de $55^{\circ} \mathrm{C}$, e a mínima de $0^{\circ} \mathrm{C}$ a $36^{\circ} \mathrm{C}$, com uma mediana de $5^{\circ} \mathrm{C}^{43}$. Um líquido com $55^{\circ} \mathrm{C}$ pode ser mantido na cavidade bucal tranqüilamente por até 15 segundos, elevando a temperatura da superfície dentária para $47^{\circ} \mathrm{C}$, enquanto temperaturas maiores causam desconforto. Quanto à temperatura mínima suportada, há relatos de até $0^{\circ} \mathrm{C}$, porém com extremo desconforto. Uma temperatura mais tolerável seria de $10^{\circ} \mathrm{C}^{43}$. Entretanto, as temperaturas de $5^{\circ} \mathrm{C}$ e $55^{\circ} \mathrm{C}$ também foram empregadas por vários outros autores ${ }^{8,15,22,50,53,59,62,67,73,75,79,82,92,104}$, o que certamente foi observado para a eleição das mesmas neste experimento. Além de provocar um estresse na interface dente-restauração, a termociclagem pode acelerar o processo de hidrólise do agente adesivo, removendo monômeros que não foram polimerizados adequadamente ${ }^{65}$ e também a dissolução do verniz cavitário ${ }^{67}$. Estas 
informações podem explicar os achados relativos à microinfiltração marginal mais variáveis e menos efetivos nos GI - CP e Gll - OS (tabela 1 e figuras 17 e 18).

Além da variabilidade nas temperaturas empregadas, há divergências quanto ao tempo de imersão em cada banho e número de ciclos. No trabalho em questão, o tempo de imersão adotado foi de 15 segundos, em concordância com outros estudos ${ }^{48,75,79,82,85}$. Sobre este aspecto também existem divergências, com tempos que variam desde 4 segundos até 20 minutos, com uma mediana de 30 segundos $^{43}$. A utilização de tempos de imersão longos resultam em um estresse térmico maior, provocando maior microinfiltração marginal. No entanto, tempos de imersão muito longos não devem ser considerados clinicamente relevantes ${ }^{88}$. Já o número de ciclos pode variar substancialmente, estando entre 1 até 1.000.000, com uma mediana de $500 \operatorname{ciclos}^{43}$, que foi o número empregado neste e em outros estudos $^{38,67,75,79,82}$.

Neste trabalho a termociclagem foi realizada em água para posterior imersão no corante, em concordância com a metodologia de diversos pesquisadores ${ }^{15,16,18,20,27,28,31,38,50,53,59,61,75,79,82,97,99}$. Contudo, alguns estudos realizam a termociclagem no corante usado para identificar a microinfiltração marginal $^{2,7,22,88,92}$. Porém, WENDT JUNIOR; McCINNES; DICKINSON ${ }^{106}$ observaram que não há diferença significante na microinfiltração marginal em amostras termocicladas diretamente no corante ou em água.

A avaliação da microinfiltração marginal possui um papel importante na pesquisa odontológica, permitindo que os investigadores avaliem a capacidade dos materiais restauradores de vedar a interface dente-restauração ${ }^{28,67}$.

Existem métodos quantitativos e qualitativos para avaliação da microinfiltração marginal. Quanto aos possíveis métodos para detectá-la, podem ser citados: exame visual - detecção de descoloração marginal, presença de margens abertas detectadas por sonda exploradora ${ }^{13}$; exame por microscopia óptica ou MEV ; quantificação da saída de íons $(\mathrm{OH})^{-}$liberados pela base de hidróxido de cálcio sob a restauração de amálgama ${ }^{13}$; utilização de corantes, como azul de metileno, fucsina básica, nitrato de prata, fluoresceína, rodamina $B^{7,13,28,60,100}$; utilização de radioisótopos $\left(\mathrm{Ca}_{45}, \mathrm{Na}_{22}, \mathrm{C}_{14}, \mathrm{~S}_{35}\right.$ e $\left.\mathrm{I}_{131}\right)$ e autorradiografias ${ }^{13,28}$; exame da penetração de bactérias; técnica do ar pressurizado ${ }^{10,13}$; técnica da liberação de flúor de restaurações de CIV $^{13}$; técnica da espectrofotometria ${ }^{67}$ e técnica da utilização de solução salina sob pressão na câmara pulpar². A liberdade de escolha e a 
diversidade de métodos existentes para detecção da microinfiltração marginal parece demonstrar que os mesmos apresentam resultados similares ${ }^{33,100}$, apesar de haver outros estudos que não indicam o mesmo ${ }^{28}$.

Segundo MORAIS; RODRIGUES JUNIOR; PIMENTA ${ }^{67}$, os corantes avaliam a microinfiltração marginal apenas de maneira parcial, já que possibilitam apenas medidas bidimensionais. Para avaliar a microinfiltração total, considerando que a mesma é tridimensional, o melhor método a ser utilizado é o da espectrofotometria $^{67}$. Todavia, a utilização de corantes orgânicos é um dos métodos mais antigos ${ }^{51}$ e difundidos para avaliar a microinfiltração em restaurações de amálgama $^{51,101}$, além da simplicidade e rapidez para a realização da técnica, possibilitando identificar o modelo de penetração do corante, que pode ocorrer na interface dente/adesivo ou adesivo/material restaurador. Dentre os vários corantes,

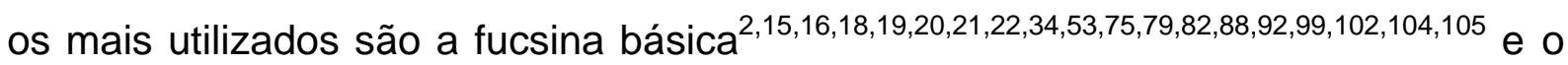
azul de metileno $8,31,37,66,109$. No presente estudo foi utilizada a fucsina básica a 0,5\% como corante para avaliação da microinfiltração marginal, sendo os dentes mantidos nesta solução por um período de 24 horas. A escolha deste corante deveu-se ao grande número de trabalhos que o utilizaram e pelo fato do mesmo fornecer um bom contraste com a estrutura dentária e o material restaurador.

Para esta avaliação, é necessário seccionar os dentes através da interface dente-restauração para possibilitar sua análise. Neste estudo foram realizados vários cortes, através dos quais foi possível obter cerca de 4 fatias por dente, as quais foram avaliadas em ambas as faces. A realização de vários cortes pode provocar o deslocamento da restauração da fatia, o que aconteceu com 4 espécimes neste estudo, mesmo com a inclusão dos dentes em resina. Apesar disso, é um método amplamente usado, já que permite uma análise do padrão de microinfiltração marginal em várias áreas da interface dente-restauração. Apesar de DÉJOU; SINDRES; CAMPS ${ }^{34}$ relatarem que a máxima penetração de corante em uma restauração é a forma mais sensível para verificar a efetividade dos materiais restauradores, a média obtida nas várias fatias talvez possa fornecer dados mais próximos do real.

A penetração do corante pode ser classificada de maneira qualitativa, através de escores, ou quantitativa, através de medidas lineares. O primeiro método é o mais utilizado 5,6,8,15,17,19,22,27,29,31,37,38,48,53,59,60,61,62,73,82,90,92; porém, apesar de ser 
usado com sucesso e ressaltar deficiências nos materiais e técnicas testados, ele avalia a microinfiltração de maneira arbitrária e subjetiva ${ }^{108}$.

YOUNGSON; GREY; GLYN JONES ${ }^{108}$ relataram que analisar somente a profundidade de penetração do corante na interface dente-restauração parece ser um método inadequado, já que isto indicaria somente a presença de um espaço entre o material restaurador e o preparo cavitário, deixando de considerar o tamanho desses espaços e o potencial de microinfiltração marginal. Eles acreditam que a análise da área indicaria o volume de corante penetrado e o tamanho dos espaços na interface. Porém, apesar da tentativa em padronizar os dentes utilizados no experimento, utilizando dentes extraídos por indicação ortodôntica, sabe-se que há variação no tempo que os mesmos permaneceram na boca, sofrendo diferentes estímulos, sejam eles térmicos, mecânicos ou químicos, o que pode influenciar na qualidade da dentina, que pode ter túbulos dentinários com diâmetros diferentes ${ }^{78}$. Além disso, nas condições in vitro não há a presença do fluido pulpar nos túbulos dentinários, o que pode modificar os resultados de microinfiltração marginal, apesar de existirem estudos que tentam simular esta condição ${ }^{2,78}$.

A utilização de métodos quantitativos, através de medidas lineares, fornece a extensão de penetração do corante com maior precisão, além de ser mais sensível que os métodos qualitativos ${ }^{75}$. Esta avaliação pode ser realizada através de microscopia $^{75,79,97}$ e, mais recentemente, foram desenvolvidos métodos que permitem realizar medidas lineares e da área infiltrada pelo corante através de imagens digitalizadas ${ }^{108}$.

A imagem visualizada pelo microscópio certamente é mais nítida, já que é a real. Com o aumento utilizado neste estudo (150 vezes), pôde-se observar claramente proporções mínimas de penetração do corante, o que provavelmente não seria possível através da utilização de microscópios que permitem menor aumento.

Já as imagens observadas pelo monitor do computador possuem uma qualidade inferior devido aos "pixels" e "sombras", o que diminuiu a nitidez e dificultou a visualização do término da penetração do corante pelo software utilizado (Sigma Scan). Para o CIV, cujos valores de microinfiltração marginal foram menores, estes dois métodos apresentaram, proporcionalmente à média, um desvio padrão inferior pela dificuldade de identificação do ponto máximo de penetração do corante. Já para os GI - CP e Gll - OS ocorreu o contrário, pois observou-se um desvio 
padrão maior proporcionalmente à média, justamente em função da microinfiltração marginal mais evidente, a qual pôde ser mais facilmente identificada nas imagens digitalizadas. Esta qualidade inferior de imagem agrava-se com aumentos maiores, o que foi preponderante na eleição do aumento de 4 vezes neste estudo, possibilitando a obtenção de uma imagem maior, porém não muito distorcida. Com o intuito de comparar este método com o microscópio, inicialmente foi realizada a medida da penetração do corante em linha única (Sigma única). Entretanto, ambos os métodos não permitiam acompanhar todo o caminho percorrido pelo corante, justamente por realizarem a medida através de uma linha reta única, desconsiderando possíveis irregularidades do preparo cavitário e a microinfiltração marginal que percorria a interface dente-restauração na parede axial. Devido a isso, também foi realizada a avaliação pelo software através de linhas segmentadas (Sigma segm.).

Pelas tabelas 1 e 5 pode-se observar que as médias obtidas pelo microscópio sempre foram maiores que as conseguidas pelo Sigma única, com diferenças estatisticamente significantes nos 3 grupos de estudo. Esta diferença provavelmente ocorreu pela maior sensibilidade do primeiro método, que permitiu a detecção de mínimas quantidades de corante, enquanto no segundo havia a presença de "sombras". Devido a este aspecto, houve uma preocupação em limitar a microinfiltração marginal somente até o local onde a presença de corante era observada com certeza. A perda de detalhes que ocorre com a avaliação utilizandose o método Sigma única explica a diferença estatística observada entre os GII - OS e GIII - VT (tabela 3). Por outro lado, mesmo a avaliação pelo Sigma segm., que permitiria a mensuração da microinfiltração marginal linearmente mais extensa, revelou não haver diferença estatisticamente significante entre os GII - OS e GIII VT (tabela 3).

Quando foram comparados os resultados entre o microscópio e o Sigma segm., houve diferença significante somente no GIII - VT (tabela 5). Comparando-se os dados obtidos pelos métodos que utilizaram o software, foi verificada diferença estatisticamente significante apenas nos GI - CP e Gll - OS. Nestes grupos pôde-se observar uma freqüência maior de penetração do corante pela parede axial, o que elevou as suas médias na avaliação pelo Sigma segm., aproximando-as dos resultados obtidos pelo microscópio e distanciando-as dos obtidos pelo Sigma única. O GIII - VT apresentou maior uniformidade nos resultados, sendo que nenhum 
espécime apresentou penetração do corante na parede axial. Por isso, os resultados obtidos pelo Sigma única e Sigma segm. neste grupo foram bastante similares e estatisticamente inferiores aos obtidos com o microscópio (tabela 5).

Apesar de apresentarem diferenças estatisticamente significantes, os três métodos de avaliação apresentaram uma forte correlação positiva (tabela 6), demonstrando que seus resultados refletiram uma semelhança no comportamento de cada material forrador estudado. Este é um dado interessante, já que o microscópio é um equipamento de custo mais elevado, o que dificulta a sua aquisição para a realização deste tipo de pesquisa. Com a evolução e popularidade dos materiais e equipamentos eletrônicos, surge mais uma alternativa que pode ser utilizada com segurança para avaliar a microinfiltração marginal permitida pelos materiais restauradores.

Os resultados do presente trabalho confirmam os dados relatados na literatura em estudos in vitro, demonstrando que nenhum dos materiais foi capaz de inibir totalmente a microinfiltração marginal. Apesar deste e de outros estudos in vitro apresentarem melhores resultados com restaurações de amálgama associadas a materiais adesivos, os poucos estudos in vivo ${ }^{12,44,76,91}$ relatam pouca vantagem deste tipo de restauração em relação às convencionais, quando são avaliadas a forma anatômica, adaptação marginal, qualidade da superfície, sensibilidade pósoperatória $^{12,44,91}$ e recorrência de cárie ${ }^{12}$. No entanto, os estudos in vivo necessitam de avaliações clínicas a longo prazo, pois experimentos de curta duração podem resultar em dados que mascaram o real comportamento do material.

É de fundamental importância que novos materiais e técnicas sejam extensamente testados e avaliados in vitro antes de serem aplicados clinicamente. Estudos in vivo longitudinais cientificamente controlados ainda são necessários para verificar se realmente os materiais adesivos devem substituir o verniz cavitário em restaurações de amálgama, considerando que a técnica operatória torna-se mais sensível e longa, o que influencia significativamente em um tratamento odontopediátrico. Somente na cavidade bucal uma restauração de amálgama pode receber todos os estresses e sofrer uma corrosão natural, com a presença de fluidos bucais, pressão hidrostática pulpar, forças mastigatórias e alterações térmicas, além da placa dentária, que possui um papel preponderante no sucesso de qualquer técnica restauradora. 
7 Conclusões 


\section{CONCLUSÕES}

A análise dos resultados obtidos através das condições experimentais deste trabalho permitiu constatar que:

$>$ as restaurações de amálgama associadas ao verniz cavitário (GI - CP) apresentaram uma microinfiltração marginal superior aos outros grupos, sendo a diferença estatisticamente significante nos três métodos de avaliação empregados;

$>$ as restaurações de amálgama associadas ao CIV (GIII - VT) apresentaram os menores valores de microinfiltração marginal, com diferença estatisticamente significante em relação ao GII - OS apenas através do método de avaliação Sigma única;

$>$ houve diferença estatisticamente significante entre os valores de microinfiltração marginal obtidos pelo microscópio em relação aos métodos Sigma única, em todos os grupos estudados, e Sigma segm., no GIII - VT, sendo os maiores valores observados pelo microscópio;

houve diferença estatisticamente significante entre os métodos Sigma única e Sigma segm. nos GI - CP e Gll - OS, com maiores valores obtidos pelo Sigma segm., e

houve uma forte correlação positiva entre os três métodos de avaliação empregados.

A análise das constatações acima permitiu concluir que:

nenhum dos três sistemas restauradores foi capaz de eliminar a microinfiltração marginal, sendo que os materiais adesivos apresentaram comportamentos semelhantes entre si e superiores ao verniz cavitário, e $>$ os métodos de avaliação estudados apresentaram confiabilidade de resultados. 


\section{Referências Bibliográficas}




\section{REFERÊNCIAS BIBLIOGRÁFICAS*}

1 ABOUSH, Y.E.Y.; ELDERTON, R.J. Bonding dental amalgam to a light-curing glass-ionomer liner/base. Brit. dent. J., v.170, n.23, p.219-22, Mar. 1991.

2 AL-JAZAIRY, Y.; LOUKA, A. Effect of bonded amalgam restorations on microleakage. Oper. Dent., v.24, n.4, p.203-9, July/ Aug. 1999.

3 AL-MOAYAD, M.; ABOUSH, Y.E.Y.; ELDERTON, R.J. Bonded amalgam restorations: a comparative study of glass-ionomer and resin adhesives. Brit. dent. J., v.20, p.363-7, Nov.1993.

4 ANDREWS, J.T.; HEMBREE JUNIOR, J.H. In vitro evaluation of marginal leakage of corrosion-resistant amalgam alloy. J. Dent. Child., v.42, n.5, p.367-70, Sept./Oct. 1975.

5 ANDREWS, J.T.; HEMBREE JUNIOR, J.H. Microleakage of several amalgam systems: an animal study. J. prosth. Dent., v.40, n.4, p.418-21, Oct. 1978.

6 ANDREWS, J.T.; HEMBREE JUNIOR, J.H. Marginal leakage of amalgam alloys with high content of copper: a laboratory study. Oper. Dent., v.5, n.1, p.7-10, Jan./Mar. 1980.

7 ARAÚJO, R.M.; MELLO, J.B.; HUHTALA, M.F.R.L. Utilização de adesivos dentinários como agente de vedamento cavitário em restaurações classe II de amálgama e resina composta posterior. Rev. Odont. UNESP, v.22, n.2, p.257-65, jul./dez. 1993.

8 ARCORIA, C.J.; FISHER, M.A.; WAGNER, M.J. Microleakage in alloy-glass ionomer lined amalgam restorations after thermocycling. J. oral Rehab., v.18, n.1, p.9-14, Jan. 1991.

9 BAGLEY, A.; WAKEFIELD, C.W.; ROBBINS, J.W. In vitro comparison of filled and unfilled universal bonding agents of amalgam to dentin. Oper. Dent., v.19, n.3, p.97-101, May/June 1994.

10 BAUER, J.G.; HENSON, J.L. Microleakage: a measure of the performance of direct filling materials. Oper. Dent., v.9, n.1, p.2-9, 1984.

\footnotetext{
* Normas recomendadas para uso no âmbito da Universidade de São Paulo, com base no documento "Referências Bibliográficas: exemplos", emanado do Conselho Supervisor do Sistema Integrado de Bibliotecas da USP, em reunião de 20 de setembro de 1990.
} 
11 BEARN, D.R.; SAUNDERS, E.M.; SAUNDERS, W.P. The bonded amalgam restorations - a review of the literature and report of its use in the treatment of four cases of cracked-tooth syndrome. Quintessence Int., v.25, n.5, p.321-6, May 1994.

12 BELCHER, M.A.; STEWART, G.P. Two-year clinical evalua tion of an amalgam adhesive. J. Amer. dent. Ass., v.128, n.3, p.309-15, Mar. 1997.

13 BEN-AMAR, A.;CARDASH, H.S. The fluid-filled gap under amalgam and resin composite restorations. Amer. J. Dent., v.4, n.5, p.226-30, Oct. 1991.

14 BEN-AMAR, A.; CARDASH, H.S.; JUDES, H. The sealing of the tooth/amalgam interface by corrosion products. J. oral Rehab., v.22, n.2, p.101-4, Feb. 1995.

15 BEN-AMAR, A.; CARDASH, H.S.; LIBERMAN, R. Varnish application technique and microleakage of amalgam restorations. Amer. J. Dent., v.6, n.2, p.101-4, Feb. 1993.

16 BEN-AMAR, A. et al. The effect on marginal microleakage of using a combination of cavity varnishes and calcium hydroxide intermediary bases an in vitro study. Quintessence Int., v.16, n.12, p.821-5, Dec. 1985.

17 BEN-AMAR, A. et al. Marginal microleakage: the effect of the number of cavity varnish layers and the type of amalgam used. Dent. Mat., v.2, n.1, p.45-7, Feb. 1986.

18 BEN-AMAR, A. et al. The control of marginal microleakage in amalgam restorations using a dentin adhesive: a pilot study. Dent. Mat., v.3, n.2, p.946, Apr. 1987.

19 BEN-AMAR, A. et al. Long-term use of dentin adhesive as an interfacial sealer under class II amalgam restorations. J. oral Rehab., v.17, n.1, p.37-42, Jan. 1990.

20 BEN-AMAR, A. et al. Long-term sealing properties of amalgambond under amalgam restorations. Amer. J. Dent., v.7, n.3, p.141-3, June. 1994.

21 BERRY, T.G.; TJAN, A.H.L. Microleakage of amalgam restorations lined with dentin adhesives. Amer. J. Dent., v.7, n.6, p.333-5, Dec. 1994.

22 BERRY, T.G. et al. Microleakage of amalgam restorations using dentin bonding system primers. Amer. J. Dent., v.9, n.4, p.174-8, Aug. 1996. 
23 BONILLA, E.; WHITE, S.N. Fatigue of resin-bonded amalgam restorations. Oper. Dent., v.21, n.3, p.122-8, May/June 1996.

24 BOSTON, D.B. Adhesive liner incorporation in dental amalgam restorations. Quintessence Int., v.28, n.1, p.49-55, Jan. 1997.

25 BURROW, M.F. et al. The influence of age and depth of dentin on bonding. Dent. Mat., v.10, n.4, p.241-6, July 1994.

26 CARVALHO, R.M. Adesivos dentinários - fundamentos para aplicação clínica. Rev. Dent. Rest., v.1, n.2, abr./jun. 1998.

27 CHAIN, M.C. Adesivo dentinário de última geração. Rev. gaúcha Odont., v.43, n.6, p.307-9, nov./dez. 1995.

28 CHARLTON, D.G.; MOORE, B.K. In vitro evaluation of two microleakage detection tests. J. Dent., v.20, n.1, p.55-8, Feb. 1992.

29 CHARLTON, D.G.; MOORE, B.K; SWARTZ, M.L. In vitro evaluation of the use of resin liners to reduce microleakage and improve retention of amalgam restorations. Oper. Dent., v.17, n.3, p.112-9, May/June. 1992.

30 CHARLTON, D.G.; MURCHISON, D.F.; MOORE, B.K. Incorporation of adhesive liners in amalgam: effect on compressive strength and creep. Amer. J. Dent., v.4, n.4, p.184-8, Aug. 1991.

31 COOLEY, R.L.; TSENG, E.Y.; BARKMEIER, W.W. Dentinal bond strengths and microleakage of a 4-meta adhesive to amalgam and composite resin. Quintessence Int., v.22, n.12, p.979-83, Dec. 1991.

32 CRIM, G.A.; GARCIA-GODOY, F. Microleakage: the effect of storage and cycling duration. J. prosth. Dent., v.57, n.5, p.574-6, May 1987.

33 CRIM, G.A.; SWARTZ, M.L.; PHILLIPS, R.W. Comparison of four thermocycling techniques. J. prosth. Dent., v.53, n.1, p.50-3, Jan. 1985.

34 DÉJOU, J.; SINDRES, V.; CAMPS, J. Influence of criteria on the results of in vitro evaluation of microleakage. Dent. Mat., v.12, n.6, p.342-9, Nov. 1996.

35 DENEHY, G.E.; COBB, D.S.; VARGAS, M.A. Amalgam shear bond to dentin using single-bottle primer/adhesives. J. dent. Res., v.77, p.153, Mar. 1998. /Abstract n.1341/.

36 DIEFENDERFER, K.E.; REINHARDT, J.W. Shear bond strengths of 10 adhesive resin/amalgam combinations. Oper. Dent., v.22, n.2, p.50-6, Mar./Apr. 1997. 
37 DUARTE JUNIOR, S.L.L. Avaliação da microinfiltração marginal em cavidades de classe $\mathbf{V}$ restauradas com amálgama. Efeito de vernizes e adesivo dentinário. Araraquara, 1995. 105p. Dissertação (Mestrado) Faculdade de Odontologia de Araraquara, Universidade Estadual Paulista "Júlio de Mesquita Filho".

38 DUTTON, F.B. et al. Effect of a resin lining and rebonding on the marginal leakage of amalgam restorations. J. Dent., v.21, n.1, p.52-6, Feb. 1993.

39 EVANS, D.B.; NEME, A.L.; HOELSCHER, D.C. A microleakage investigation of seven amalgam and composite adhesive systems. J. dent. Res., v.77, p.154, Mar. 1998. /Abstract n.385/.

40 FANIAN, F.; HADAVI, F.; ASGAR, K. Marginal microleakage of dental amalgams: effect of cavity varnish and burnishing. J. Canad. dent. Ass., v.50, n.6, p.484-7, June/July 1984.

41 FITCHIE, J.G. et al. Microleakage of a new cavity varnish with a high-cooper spherical amalgam alloy. Oper. Dent., v.15, n.4, p.136-40, July/Aug. 1990.

42 FRIEDL, K.; POWERS, J.M.; HILLER, K.A. Influence of different factors on bond strength of hybrid ionomers. Oper. Dent., v.20, n.2, p.74-80, Mar./Apr. 1995.

43 GALE, M.S; DARVELL, B.W. Thermal cycling procedures for laboratory testing of dental restorations. J. Dent., v.27, n.2, p.89-99, Feb. 1999.

44 GORDAN, V.V. et al. Effect of different liner treatments on postoperative sensitivity of amalgam restorations. Quintessence Int., v.30, n.1, p.55-9, Jan. 1999.

45 GWINNETT, A.J. et al. Adhesive restorations with amalgam: guidelines for the clinician. Quintessence Int., v.25, n.10, p.687-95, Oct. 1994.

46 HALLER, B. et al. Effect of storage media on microleakage of five dentin bonding agents. Dent. Mat., v.9, n.1, p.191-7, May 1993.

47 HILTON, T.J. Cavity sealers, liners, and bases: current philosophies and indications for use. Oper. Dent., v.2, n.4, p.134-46, July/Aug. 1996.

48 HOLLIS, R.A. et al. Shear strenght \& microleakage of 14 amalgam bonding adhesives. J. dent. Res., v.75, p.387, 1996. Special issue. /Abstract n.2958/

$49 \mathrm{HOSHI}, \mathrm{A} . \mathrm{T}$. et al. Avaliação de um cimento de ionômero de vidro como selante. In: JORNADA ODONTOLÓGICA DE BAURU, 10, Bauru, 1997. Anais. Bauru, Faculdade de Odontologia de Bauru, 1997. p.117. 
50 KELSEY, W.P.; PANNETON, M.J. A comparison of amalgam microleakage between a copal varnish and two resin compatible cavity varnishes. Quintessence Int., v.19, n.12, p.895-8, Dec. 1988.

51 KIDD, E.A. Microleakage: a review. J. Dent., v.4, n.5, p.199-206, Sept. 1976.

52 KILPATRICK, N.M. Durability of restorations in primary molars. J. Dent., v.21, n.1, p.67-73, Feb. 1993.

53 KORALE, M.E.; MEIERS, J.C. Microleakage of dentin bonding systems used with spherical and admixed amalgams. Amer. J. Dent., v.9, n.6, p.249-52, Dec. 1996.

54 KULAPONGS, K.J.; MOORE, B.K.; COCHRAN, M.A. Microleakage of resin-lined amalgams using confocal microscopy and fluorescent markers. J. dent. Res., v.77, p.243, Mar. 1998. /Abstract n.1100/.

55 LINDEMUTH, J.S.; HAGGE, M.S.; BROOME, J.S. Effect of restorations size on fracture resistance of bonded amalgam restorations. Oper. Dent., v.25, n.3, p.177-81, May/June 2000.

56 LUND, N.H.; MATTHEWS, J.L.; MILLER, A.M. Cavity varnish and its application: "once is not enough". J. prosth. Dent., v.40, n.5, p.543-7, Nov. 1978.

57 MAHLER, D.B. The amalgam-tooth interface. Oper. Dent., v.21, n.6, p.230-6, Nov./Dec. 1996.

58 MAHLER, D.B. et al. One-year clinical evaluation of bonded amalgam restorations. J. Amer. dent. Ass., v.127, n.3, p.345-9, Mar. 1996.

59 MANDERS, C.A.; GARCIA-GODOY, F.; BARNWELL, G.M. Effect of a copal varnish, ZOE or glass ionomer cement bases on microleakage of amalgam restorations. Amer. J. Dent., v.3, n.2, p.63-6, Apr. 1990.

$60 \mathrm{MARCHIORI}$, S. et al. The use of liners under amalgam restorations: an in vitro study on marginal leakage. Quintessence Int., v.29, n.10, p.637-42, Oct. 1998.

61 MCCOMB, D.; BEN-AMAR, A.; BROWN, J. Sealing efficacy of therapeutic varnishes used with silver amalgam restorations. Oper. Dent., v.15, n.4, p.122-8, July/Aug. 1990.

62 MEIERS, J.C.; TURNER, E.W. Microleakage of dentin/amalgam alloy bonding agents: results after 1 year. Oper. Dent., v.23, n.1, p.30-5, Jan./Feb. 1998.

63 MERTZ-FAIRHURST; E.J.; NEWCOMER, A.P. Interface gap at amalgam margins. Dent. Mat., v.4, p.122-8, 1988. 
64 MILLSTEIN, P.L.; NAGUIB, G.H. Effects of two resin adhesives on mechanical properties of set amalgam. J. prosth. Dent., v.74, n.1, p.106-9, July 1995.

65 MIYAZAKI, M.; SATO, M.; ONOSE, H. Durability of enamel bond strength of simplified bonding systems. Oper. Dent., v.25, n.2, p.75-80, Mar./Apr. 2000.

66 MOORE, D.S.; WILLIAN, W.W.; KAPLAN, I. A comparison of amalgam microleakage with a 4-meta liner and copal varnish. Int. J. Prosth., v.8, n.5, p.461-6, 1995.

67 MORAIS, P.M.R.; RODRIGUES JUNIOR, A.L.; PIMENTA, L.A. Quantitative microleakage evaluation around amalgam restorations with different treatments on cavity walls. Oper. Dent., v.24, n. 4, p.217-22, July/ Aug. 1999.

68 MURRAY, G.A.; YATES, J.L.; WILLIANS, J.I. Effect of 4 cavity varnish and a fluoride solution on microleakage of dental amalgam restorations. Oper. Dent $_{2}$, v.8, p.148-51, 1983.

69 NAVARRO, M.F.L.; PASCOTTO, R. Cimentos de ionômero de vidro. In:_ Cimentos de ionômero de vidro. São Paulo, Artes Médicas, 1998. Cap.1, p.1-24.

70 NELSEN, R.J.; WOLCOTE, R.B.; PAFFENBARGER, G.C. Fluid exchange at the margins of dental restorations. J. amer. dent. Ass., v.44, p.288-95, 1952.

71 NEWMAN, S.M. Microleakage of a copal resin cavity varnish. J. prosth. Dent., v.51, n.4, p.499-502, Apr. 1984.

72 NEWMAN, S.M.; SZOJKA, F. Effects of high-cooper alloys on microleakage changes across time. J. dent. Res., v.65,p.219, 1986. Special Issue./ Abstract n.448/

73 NEWMAN JUNIOR, J.E.; HONDRUM, S.O.; CLEM, D.B. Microleakage under amalgam restorations lined with copalite, amalgambond plus, and vitrebond. Gen. Dent., v.44, n.3, p.340-4, July/Aug. 1996.

74 NG, B.P.; PURTON, D.G.; HOOD, J.A.A. Effects of lining materials on shear bond strength of amalgam and galliun alloy restorations. Oper. Dent., v.23, n.3, p.113-20, Mar./Apr. 1998.

75 OLIVEIRA, F.S. Avaliação “in vitro” da microinfiltração marginal de restaurações de amálgama classe II associada a adesivos dentinários. Bauru, 1997. 158p. Dissertação (Mestrado) - Faculdade de Odontologia de Bauru, Universidade de São Paulo. 
76 ÖLMEZ, A.; CULA, S.; ULUSU, T. Clinical evaluation and marginal leakage of Amalgambond plus: three-year results. Quintessence Int., v.28, n.10, p.6516, Oct. 1997.

77 PALMER, A.E. et al. Fracture strength of class 2 amalgam with various cavitylining materials. Oper. Dent., v.24, n.1, p.45-50, Jan./Feb. 1999.

78 PASHLEY, D.H. et al. Adhesion testing of dentin bonding agents: a review. Dent. Mat., v.11, n.2, p.117-25, Mar. 1995.

79 PEREIRA JÚNIOR, E.S. Avaliação “in vitro” da microinfiltração marginal em restaurações de amálgama adesivo tipo classe II com adesivo dentinário e com cimento de ionômero de vidro. Bauru, 1997. 141p. Dissertação (Mestrado) Faculdade de Odontologia de Bauru, Universidade de São Paulo.

80 PHILLIPS, R.W. Ligas para amálgama dentário e estrutura do amálgama. In: Materiais dentários de Skinner. 8 ed. Rio de Janeiro, Interamericana, 1984, p.219-41.

81 PIMENTA, L.A. et al. Inhibition of demineralization in vitro around amalgam restorations. Quintessence Int., v.29, n.6, p363-7, June 1998.

82 PINTO, M.B. Avaliação da infiltração marginal em restaurações com amálgama utilizando como materias intermediários verniz cavitário e diferentes sistemas adesivos. Bauru, 1997. 209p. Dissertação (Mestrado) Faculdade de Odontologia de Bauru, Universidade de São Paulo.

83 POWELL, G.L.; DAINES, D.T. Solubility of a cavity varnish: a study in vitro. Oper. Dent., v.12, n.2, p.48-52, Apr. 1987.

84 PRATI, C.; PASHLEY, D.H.; MONTANARI, G. Hydrostatic intrapulpal pressure and bond strength of bonding systems. Dent. Mat., v.7, n.1, p.54-8, Jan. 1991.

85 RETIEF, D.H. Standardizing laboratory adhesion tests. Amer. J. Dent., v.4, n.5, p.231-6, Oct. 1991.

86 RODRIGUES, J.A. et al. In vitro microleakage of glass-ionomer composite resin hybrid materials. Oper. Dent., v.24, n.2, p.89-95, Mar./Apr. 1999.

87 ROSEN, A.T.; HERMESCH, C.B.; SUMMITT, J.B. Resistance of bonded complex amalgam restorations with and without pins. J. dent. Res., v.77, p.153, Mar. 1998. /Abstract n.383/. 
88 ROSSOMANDO, K.J.; WENDT JUNIOR, S.L. Thermocycling and dwell times in microleakage evaluation for bonded restorations. Dent. Mat., v.11, n.1, p.4751, Jan. 1995.

89 ROULET, J.F. Benefits and disadvantages of tooth-coloured alternatives to amalgam. J. Dent., v.25, n.6, p.459-73, Nov. 1997.

90 ROYSE, M.C.; OTT, N.W.; MATHIEU, G.P. Dentin adhesive superior to copal varnish in preventing microleakage in primary teeth. Pediat. Dent., v.18, n.7, p.440-3, Nov./ Dec. 1996.

91 RUZICKOVA, T. et al. Bonded amalgam restorations: two year clinical results. J. dent. Res., v.76, p.67, 1997. Special issue. /Abstract n.426/.

92 SAIKU, J.M.; GERMAIN JUNIOR, H.A.; MEIERS, J.C. Microleakage of dental amalgam alloy bonding agent. Oper. Dent., v.18, n.5, p.172-8, Sept./Oct. 1993.

93 SANO, $\mathrm{H}$. et al. Relationship between surface area for adhesion and tensile bond strenght - evaluation of micro-tensile bond test. Dent. Mat., v.10, n.4, p.236-40, July 1994.

94 SEPETCIOGLU, F.; ATAMAN, B.A. Long-term monitoring of microleakage of cavity varnish and adhesive resin with amalgam. J. prosth. Dent., v.79, n.2, p.136-9, Feb. 1998.

95 SETCOS, J.C.; STANINEC, M.; WILSON, N.H.F. The development of resinbonding for amalgam restorations. Brit. dent. J., v.186, n.7, p.328-32, Apr. 1999.

96 SETCOS, J.C.; STANINEC, M.; WILSON, N.H.F. Bonding of amalgam restorations: existing knowledge and future prospects. Oper. Dent., v.25, n.2, p.121-9, Mar./Apr. 2000.

97 SILVA, M. et al. Base-varnish interactions around amalgam restorations: spectrophotometric and microscopic assesment of leakage. Aust. dent. J., v.30, n.2, p.89-95, Apr. 1985.

98 SNEED, W.; HEMBREE JUNIOR, J.H.; WELSH, E.L. Effectiveness of three cavity vanishes in reducing leakage of a high-cooper amalgam. Oper. Dent., v.9, n.1, p. 32-4, Jan. 1984.

99 STANINEC, M.; HOLT, M. Bonding of amalgam to tooth structure: tensile adhesion and microleakage test. J. prosth. Dent., v.59, n.4, p.397-402, Apr. 1988. 
100 TANGSGOOLWATANA, J. et al. Microleakage evaluation of bonded amalgam restorations: confocal microscopy versus radioisotope. J. dent. Res., v.75, p.22, 1996. Special Issue. /Abstract n.1235/

101 TAYLOR, M.J.; LYNCH, E. Microleakage. J. Dent., v.20, n.1, p.3-10, Feb. 1992. 102 TJAN, A.H.L. et al. Marginal leakage of amalgam restorations pretreated with various liners. Amer. J. Dent., v.10, n.6, p.284-6, Dec. 1997.

103 TORRI, Y. et al. Inhibition in vitro of caries around amalgam restorations by bonding amalgam to tooth structure. Oper. Dent., v.14, n.3, p.142-8, 1989.

104 TURNER, E.W.; GERMAIN JUNIOR, H.A.; MEIERS, J.C. Microleakage of dentin-amalgam bonding agents. Amer. J. Dent., v.8, n.4, p.191-6, Aug. 1995.

105 VARGA, J.; MATSUMURA, H.; MASUHARA, E. Bonding of amalgam filling to tooth cavity with adhesive resin. Dent. Mat., v.5, n.2, p.158-64, Dec. 1986.

106 WENDT JUNIOR, S.L.; McCINNES, P.M.; DICKINSON, G.L. The effect of thermocycling in microleakage analysis. Dent. Mater., v.8, n.3, p.181-4, May 1992.

107 WILSON, A.D.; McLEAN, I.W. Glass - ionomer cement. Chicago, Quintessence, 1988.

108 YOUNGSON, C.C.; GREY, N.J.A.; GLYN JONES, J. In vitro marginal microleakage: examination of measurements used in assessment. J. Dent., v.18, n.3, p.142-6, June 1990.

109 YU, X.; WEI, G.; XU, J. Experimental use of a bonding agent to reduce marginal microleakage in amalgam restorations. Quintessence Int., v.18, n.11, p.7837, Nov. 1987. 
Abstract $=$ 


\section{ABSTRACT}

Dental amalgam is still largely utilized in pediatric dentistry, since it is highly resistant, insoluble in buccal fluids, easy to work, has a low cost and is not a highly and technically sensitive material. Its great disadvantage is the lack of adhesion to dental structure, associated with marginal microleakage. Nevertheless, these problems tend to be reduced through its association with dentinal adhesives or glass ionomer cements (GIC), when compared with cavity varnish. This in vitro study evaluated the marginal microleakage in amalgam restorations associated with Copalite cavity varnish - Cooley \& Cooley (GI - CP), OptiBond Solo dentinal adhesive - Kerr (GII - OS) and GIC Vitremer - 3M Dental Products (GIII - VT). Fortyfive sound and extracted premolars which received independent class II cavities in the mesial and distal surfaces, involving the marginal ridges were utilized. All the cavities were restored with Dispersalloy - Dentsply and the teeth were then thermocycled at the temperatures of $5^{\circ} \mathrm{C}$ and $55^{\circ} \mathrm{C}$ for 500 cycles in deionized water with a 15 seconds dwell time. The teeth were then immersed in 0,5\% basic fuchsin solution for 24 hours, at $37^{\circ} \mathrm{C}$. Following this period, they were rinsed in tap water for 24 hours and mesio-distally sectioned. The slices obtained were assessed in a light microscope at x150 (Mitutoyo TM-505) and with the Sigma Scan software by utilizing single and segmented lines. The data analysis allowed to establish that none of the materials was capable of eliminating marginal microleakage, being $\mathrm{GI}$ - CP the one to present the greatest and statistically significant values in relation to the remaining groups, in all evaluation methods. The smallest values were obtained by GIII - VT, however, without statistically significant difference when compared with GII - OS, except by Sigma Scan evaluation in a single line for a $p<0,05$. The three methods of linear measurement evaluation showed a strong and positive correlation, although they presented statistically different results among them in at least one of the study groups. 